UNIVERSIDADE DE SÃO PAULO

FACULDADE DE FILOSOFIA, LETRAS E CIÊNCIAS HUMANAS

DEPARTAMENTO DE LETRAS CLÁSSICAS E VERNÁCULAS

PROGRAMA DE PÓS-GRADUAÇÃO EM

FILOLOGIA E LÍNGUA PORTUGUESA

\title{
MARCADORES CONVERSACIONAIS NA INTERLÍNGUA \\ DE APRENDIZES DE ESPANHOL NO BRASIL
}

Eliane Gonçalves

Tese apresentada ao Programa de Pós-Graduação em

Filologia e Língua Portuguesa, do Departamento de

Letras Clássicas e Vernáculas da Faculdade de Filosofia,

Letras e Ciências Humanas da Universidade de São Paulo, para obtenção do título de Doutor em Letras.

Orientadora: Prof ${ }^{\mathrm{a}}$ Dr$^{\mathrm{a}}$ Maria Lúcia da Cunha Victório de Oliveira Andrade

São Paulo

2006 
Comissão Examinadora 
Ao теи pai,

que já não poderá ver mais este passo que dou e que é fruto do seu esforço e da sua crença de que a educação e o conhecimento são o que de mais sagrado e indelével o ser humano pode construir. 


\section{AGRADECIMENTOS}

Agradeço, especialmente, à minha orientadora, $\operatorname{Prof}^{\mathrm{a}} \operatorname{Dr}^{\mathrm{a}}$ Maria Lúcia da Cunha Victório de Oliveira Andrade que, mais do que orientar-me, foi uma grande amiga, presente nos momentos mais difíceis desta minha trajetória acadêmica e pessoal e cuja paciência possibilitou que eu chegasse até aqui.

Agradeço à Comissão de Ensino e Pesquisa da Pontifícia Universidade Católica de São Paulo, pela bolsa-capacitação docente concedida para que eu pudesse desenvolver adequadamente esta pesquisa;

Agradeço à minha mãe, Júlia, e minhas irmãs, Edeli e Lucimar, que me encorajaram no dia a dia e acreditaram no meu trabalho;

Agradeço o incentivo inestimável da minha boa aluna Abigail, que um dia estará no mesmo caminho;

Agradeço minhas colegas da PUC - Sandra e Paulina - pelo apoio inigualável que me deram em todos os momentos;

Agradeço especialmente à Vanessa, com sua preciosa paciência;

Agradeço aos meus informantes, alunos dedicados e que prontamente aceitaram colaborar com este trabalho

e

Agradeço, carinhosamente, ao meu grande companheiro Luís Rogério da Silva que, com seu amor, estimula-me e me fortalece há tanto tempo... 


\section{Resumo}

A produção oral de aprendizes de língua estrangeira se insere no âmbito das atividades lingüísticas desenvolvidas pelo homem e se realiza mediante a cooperação entre os seus falantes e o uso de estratégias que possam garantir a interação. Em estágios de aquisição/aprendizagem de uma língua estrangeira, observa-se que um dos recursos utilizados pelos alunos para obter sucesso nas situações de interação é o uso de marcadores conversacionais. Nesse sentido, o marcador conversacional foi o foco desta pesquisa com vistas à identificação de possíveis padrões de seu uso na interlíngua de aprendizes de espanhol falantes do português. Procedeu-se à gravação de oito diálogos espontâneos com alunos de um curso de Letras-espanhol, com temática específica, e escolheu-se aleatoriamente os dez primeiros minutos de conversação para a sua transcrição. Os resultados obtidos apontam para o fato de que os aprendizes criam estratégias comuns e apresentam padrões no desencadeamento do uso dos marcadores. O resultado desta pesquisa poderá auxiliar os professores não somente no tocante aos estudos sobre aquisição de línguas materna ou estrangeira, como também no desenvolvimento de estratégias que contribuam para que seus alunos tenham uma maior competência lingüística e conversacional. 


\begin{abstract}
The oral output of foreign language learners is part of the linguistic activities performed by man and takes place through the cooperation of the speakers and the use of strategies that are able to ensure interaction. In the stages of acquiring/learning a foreign language, we observe that among the resources used by learners in order to interact successfully we find conversation markers. Therefore, conversation markers are the focus of this research aimed at identifying possible usage patterns in the speech of learners of Spanish who speak Portuguese as a first language. To attain our goal we recorded eight spontaneous conversations with a group of under-graduate students of Spanish. All the conversations were about a specific topic and we randomly chose the first ten minutes of each recording to be transcribed. The results obtained show that language learners create common strategies and follow a certain pattern when using said markers. The results obtained can help teachers, not only in studying the acquisition of first and foreign language, but also in developing strategies which contribute to their students achieving greater linguistic and conversational competence.
\end{abstract}




\section{SUMÁRIO}

Introdução

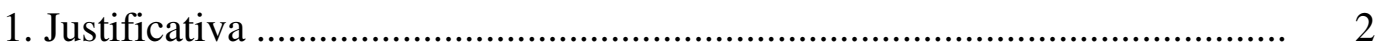

2. Objetivos ................................................................................................. 4

3. Constituição do corpus .............................................................................. 5

4. Procedimentos metodológicos …................................................................... 8

5. Delimitação .......................................................................................... 9

6. Organização do trabalho ........................................................................ 10

Capítulo I - A língua falada

1. Reflexões sobre conceito de língua, linguagem e fala ............................... 13

2. Uso, norma e sistema …........................................................................ 15

3. Contribuições da Pragmática e da Análise da Conversação ........................ 19

4. Considerações sobre língua, linguagem e fala .......................................... 21

Capítulo II - Aquisição de linguagem e aquisição de língua materna

1. As diferentes concepções de linguagem e suas áreas de estudo .................. 25

2. Principais estudos sobre aquisição de linguagem ........................................ 27

3. Aquisição de língua materna: algumas considerações ............................... 31

Capítulo III - Aquisição e aprendizagem de língua estrangeira

1. Língua Estrangeira e Segunda Língua: em torno ao conceito ..................... 41

2. Aquisição ou aprendizagem: outra controvérsia conceitual ......................... 43

3. As estratégias de aprendizagem ................................................................ 49

4. Competências necessárias para o aprendiz de língua estrangeira ................ 53 
Capítulo IV - Os marcadores conversacionais: uma perspectiva textualinterativa

1.A análise da conversação: parâmetros teóricos para esta pesquisa 64

1.1 A base Pragmática ................................................................................ 64

1.2 Uma nova corrente: a Análise da Conversação ....................................... 70

2. Os marcadores conversacionais ….......................................................... 84

2.1 Origem dos estudos sobre marcadores conversacionais $\quad$.......................... 84

2.2 Perspectivas atuais para o estudo dos marcadores conversacionais ........... 92

3. Os marcadores conversacionais e a aquisição/aprendizagem de línguas

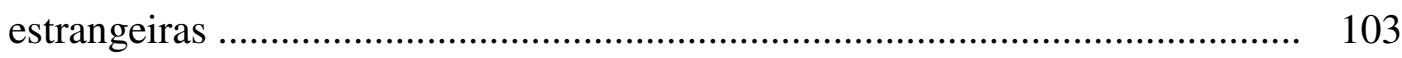

4. O marcador "então"/"entonces": um breve estudo analítico ........................ 116

Capítulo V - Os marcadores conversacionais na interlíngua dos aprendizes de língua estrangeira

1. Para uma análise dos marcadores discursivos 130

2. Análise dos resultados ............................................................................ 138

Considerações Finais .............................................................................. 149

Referências Bibliográficas ....................................................................... 153

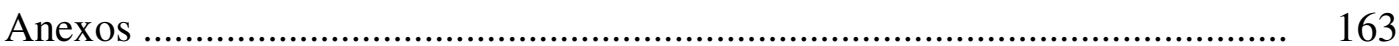


INTRODUÇÃO 


\section{Justificativa}

Os marcadores conversacionais têm sido largamente estudados desde o início das primeiras pesquisas na área da Análise da Conversação. Passaram de simples palavras expletivas da língua a elementos de grande importância nos processos de interação conversacional, marcas lingüísticas polifuncionais que podem exercer desde funções meramente conectivas (sintáticas) até metadiscursivas (comunicativas).

Entretanto, o seu estudo tem sido realizado tradicionalmente a partir de textos falados da língua materna, recebendo pouca ou nenhuma atenção quando se trata de produção oral durante o período de aprendizagem de línguas estrangeiras, mais especificamente da interlíngua dos aprendizes.

A produção oral de aprendizes de língua estrangeira se insere no âmbito das atividades lingüísticas desenvolvidas pelo homem e, como na língua materna, se realiza mediante a cooperação entre os seus falantes e estratégias que garantam a interação entre eles, para que possam alcançar o seu objetivo final, a saber, compreender-se mutuamente em um idioma que não é o seu. A compreensão entre os aprendizes se dá mediante o uso de estratégias muito específicas que podem ou não representar o mesmo uso para a interação em língua materna e, nesse contexto, as marcas lingüísticas (verbais ou não verbais) passam a representar um papel tão importante quanto seria o domínio do outro idioma. O uso dos marcadores conversacionais é um dos recursos utilizados pelos alunos e sua presença na fala dos interlocutores é significativa para a conversação desenvolvida entre eles.

Nesse sentido, o marcador conversacional também merece ser estudado como um dos elementos presentes na interlíngua, posto que os estudos na área da Análise da Conversação já comprovaram seu importante papel na produção oral da língua materna. Deixá-lo de fora nas pesquisas sobre aquisição/ aprendizagem de línguas estrangeiras é negar todos os estudos realizados 
naquele campo da ciência e sonegar ao próprio estudante um recurso que pode ajudá-lo a desenvolver-se na língua estrangeira com a mesma naturalidade com que adquiriu a língua materna.

Por esse motivo e impulsionada pelo desejo de compreender melhor a ocorrência desses elementos no processo de aquisição e aprendizagem de língua estrangeira, esta pesquisa estuda a presença dos marcadores conversacionais no contexto de produção oral de aprendizes de espanhol, baseando-se na hipótese de que de alguma forma há uma relação significativa entre níveis de aprendizagem/ conhecimento em uma língua estrangeira e uso dessas marcas lingüísticas.

A hipótese desta tese é de que o texto oral ganha consistência através do uso combinado de marcadores entre os falantes, de tal forma que, possamos considerar que um diálogo representa, em padrões de uso, o contexto de enunciação.

Os resultados poderão trazer novas perspectivas não somente no tocante à aquisição de línguas materna ou estrangeira, como também na necessidade de novas estratégias de ensino.

A partir da análise estatística da presença desses elementos procurou-se averiguar se existiam padrões de uso e comportamento que pudessem definir em que medida os marcadores estão presentes dentro de cada nível de aprendizagem, níveis categorizados por um certo sentido aleatório e subjetivo de análise por parte dos professores e cursos de línguas como Básico e Intermediário. Este fato por si só é de fundamental importância como um meio complementar para que se possa avaliar, no momento de inserção de um novo aluno, qual será o estágio mais adequado a ele, sendo esta a relevância deste trabalho, considerando-se a inexistência de pesquisas na área e as novas tendências educacionais, sejam em estudos presenciais ou a distância. 


\section{Objetivos:}

Esta pesquisa se fundamenta em estudos na área da Análise da Conversação, dentro de uma perspectiva textual-interativa e com forte apoio de dados estatísticos colhidos e analisados de acordo com a freqüência com que se apresentam nas produções orais dos interlocutores.

São os seguintes os objetivos da pesquisa:

\section{a) Geral:}

- Proceder à análise da presença dos marcadores conversacionais a partir de uma perspectiva textual-interativa no âmbito da construção enunciativa de falantes brasileiros aprendizes de espanhol, nos dois subgrupos escolhidos a partir dos níveis de conhecimento pré-estabelecidos pelos cursos de línguas que freqüentam, visando contribuir para as pesquisas sobre os marcadores conversacionais quer sejam de língua materna ou de língua estrangeira e para as pesquisas relativas ao ensino/aprendizagem de línguas.

b) Específicos:

- Compreender a freqüência e a função dos marcadores em língua portuguesa e em língua espanhola com a interlíngua dos aprendizes de espanhol do Brasil.

- Observar como se processa a interação entre aprendizes de línguas estrangeiras mediante o uso dos marcadores quer sejam os de língua materna ou os do outro idioma; 
- Detectar a existência de um padrão no uso dos marcadores pelos interlocutores;

- Avaliar a presença de marcadores da língua materna e sua relação no desenvolvimento da produção oral em língua estrangeira.

\section{Constituição do corpus}

A pesquisa foi construída a partir de um corpus de língua oral obtido através da gravação de dezesseis falantes, divididos em oito pares, sendo que quatro pertencentes ao nível Básico e quatro ao nível Intermediário de conhecimento e aprendizagem da língua estrangeira, de acordo com as classificações seguidas pelas escolas de idiomas. Os alunos realizaram, portanto, uma conversa com somente um interlocutor, constituindo-se, assim, um corpus do tipo "Diálogos".

As gravações foram feitas com estudantes do curso de Letras-Espanhol de uma universidade localizada na cidade de São Paulo, cuja faixa etária variou entre 18 e 35 anos, e procurou-se estabelecer duplas que tivessem aproximadamente a mesma idade, bem como afinidades entre si e o mesmo nível de conhecimento do idioma. Para isto, recorreu-se a alunos de uma mesma sala de aula e que tivessem, dentro dos seus níveis, um desempenho oral considerado alto por seus professores. Devido às dificuldades para encontrar informantes nessas condições, não foi possível estabelecer duplas homogêneas quanto ao sexo, tendo-se, ao final, um maior número de mulheres do que de homens, que ficaram assim distribuídos: 
- F1A : Básico 2

- F1B: Básico 2

- F2A: Básico 2

- F2B: Básico 1

- F3A: Intermediário 1

- F4A: Intermediário 1

- F5A: Intermediário 1

- F6A: Intermediário 2
20 e 24 anos - duas mulheres

18 e 21 anos - duas mulheres

21 e 23 anos - um homem e uma mulher

19 e 20 anos - dois homens

18 e 23 anos - duas mulheres

20 e 23 anos - duas mulheres

19 e 24 anos - duas mulheres

24 e 33 anos - duas mulheres

Os participantes foram informados sobre a gravação e, de modo parcial, sobre a pesquisa - souberam que seriam informantes de uma pesquisa na Área da Análise da Conversação e que não seriam investigados com relação a tópicos como: análise de erros, correção ou fluência - mas não foram informados, até o término da conversação, que se tratava da busca de marcadores em suas produções orais. Este fato, associado ao desconhecimento do tema proposto para a discussão, caracterizam essas produções como conversações espontâneas, posto que os informantes não puderam preparar antecipadamente suas falas.

Estabeleceu-se um tema polêmico que pudesse gerar uma conversação o mais próxima possível de um diálogo espontâneo e que, ao mesmo tempo, garantisse a manutenção do discurso por pelo menos vinte minutos, precaução necessária em se tratando de alunos aprendizes de um idioma estrangeiro e de níveis iniciais de aprendizagem. O tema proposto foi o mesmo para todos os grupos, independentemente do nível de conhecimento do idioma estrangeiro. 0 documentador propôs que as duplas opinassem sobre um problema que vinha Ihes causando certa preocupação: "o fato de que uma amiga, casada há 10 anos, mãe de um filho de 9 anos, estava relacionando-se com outro homem fora do casamento". O exemplo foi dado como mero pano de fundo para causar impacto e estimular a discussão, pois, na verdade, a questão que realmente se propunha era 
que se discutisse o tema da "Infidelidade", tema este sabidamente polêmico, mas altamente rentável em termos de discussões em grupos de amigos.

Para a transcrição, foram selecionados, de forma aleatória, os primeiros dez minutos de conversa entre os falantes de cada dupla e consideradas somente as participações dos interlocutores, desprezando-se as intervenções ocasionais do documentador. O papel do documentador restringiu-se a propor o problema fictício e de promover a continuidade do diálogo sempre que necessário. A transcrição foi realizada a partir das normas estabelecidas pelo Projeto de Estudos da Norma Lingüística Urbana Culta de São Paulo (Projeto NURC/SP) ${ }^{1}$.

A análise se baseia nas transcrições dos diálogos realizados e na audição das gravações, posto que somente com a audição do evento oral se consegue observar os aspectos envolvidos na conversação e distinguir determinados elementos da língua, como, por exemplo, as marcas lingüísticas - neste caso, principalmente os marcadores. Essa necessidade se amplia quando estão em jogo duas línguas tão semelhantes, como é o caso do português e do espanhol.

\footnotetext{
${ }^{1}$ Os critérios do Projeto NURC/SP utilizados foram os seguintes:

Pausa

Interrupção

Alongamento de vogal ou consoante final Incompreensão de palavras

Hipótese do que se ouviu

Entoação enfática

Comentários descritivos do transcritor

Superposição, simultaneidade de vozes

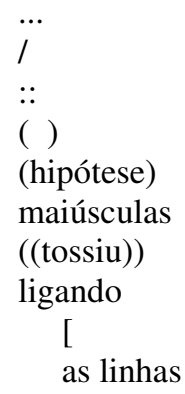

Obs.: Não se utilizam sinais de pausa, típicos da língua escrita, como ponto-e-vírgula, ponto final, dois pontos, vírgula. Também não se utilizam as iniciais maiúsculas em início de períodos, turnos e frases. 


\section{Procedimentos Metodológicos}

Os procedimentos metodológicos trabalhados basearam-se em:

- Levantamento dos principais trabalhos sobre aquisição e aprendizagem de línguas (materna e estrangeira), visando a definir a diferença entre aquisição e aprendizagem a partir do desenvolvimento de habilidades de expressão e de interação social por meio de uma língua, uma visão cognitiva da aquisição/aprendizagem de línguas;

- Revisão dos conceitos de língua falada, a fim de delimitar o registro utilizado pelos falantes aprendizes de língua estrangeira e a relação existente entre o registro utilizado e os marcadores conversacionais;

- Aprofundamento teórico sobre questões relativas à construção do texto conversacional; especialmente sobre aquelas que abordam o uso dos marcadores conversacionais;

- Levantamento das principais diferenças terminológicas e tipológicas atribuídas aos marcadores conversacionais com relação a suas funções na interação, com vistas a correlacionar a sua presença com a coesão e a coerência do discurso oral no momento de sua produção;

- Criação de um modus operandis, para o tratamento dos dados levantados, qual seja: seleção, gravação, formulação de uma ficha sociolingüística e transcrição das produções orais dos aprendizes de língua espanhola; delimitação e análise do corpus e determinação das variáveis envolvidas no processo de aprendizagem. 
- Tratamento dos marcadores conversacionais a partir da perspectiva do ensino/aprendizagem de línguas estrangeiras, a fim de verificar sua freqüência na interlíngua do aprendiz, quer sejam marcadores da língua materna e/ou da língua estrangeira, bem como sua relação com o tópico discursivo desenvolvido e a construção do texto conversacional e da competência comunicativa.

- Análise da presença dos marcadores conversacionais em diálogos espontâneos gravados com alunos aprendizes de língua espanhola, com vistas a averiguar, a partir da sua freqüência, se existe um padrão no uso desses marcadores, considerando-se as análises estatísticas e a sua aplicabilidade aos princípios da Análise da Conversação e proceder à formulação das conclusões.

\section{Delimitação}

Os marcadores são analisados dentro de uma perspectiva textual-interativa em que a produção oral é observada a partir da sua relação com o contexto e com as condições de produção.

A análise a partir de diálogos realizados entre aprendizes de língua estrangeira possibilita a observação tanto de marcadores do português como do espanhol, no entanto, dada a amplitude de sua presença no texto falado, este trabalho se limita ao estudo dos marcadores verbais lexicais e não-lexicais, de acordo com a terminologia de Marcuschi (1986, p. 62), incluídos nos primeiros os que compõem apenas uma palavra ou uma pequena frase e, no segundo, as pausas preenchidas.

Esta pesquisa consiste, no primeiro momento, em constatar o uso de marcadores conversacionais empregados pelos aprendizes de espanhol em sua produção oral e averiguar se existe um padrão de comportamento dentro de cada grupo. No segundo momento, fazer uma avaliação lingüística dos resultados 
obtidos, relacionando-os com a questão da aprendizagem de língua estrangeira e possível interferência da língua materna nesse processo e uso dos marcadores.

\section{Organização do Trabalho}

Esta tese está organizada da seguinte forma:

- Introdução - Justificativa da escolha do tema, onde se discorre sobre os motivos que levaram à pesquisa, bem como sua importância $e$ relevância dentro do contexto atual de aquisição e ensino de línguas estrangeiras, tendo como aprendizes os falantes nativos de português do Brasil; formulação dos objetivos, constituição do corpus, procedimentos adotados, delimitação e organização do trabalho.

- Capítulo I: A língua falada - reflexões sobre os conceitos e teorias que envolvem língua, linguagem e fala.

- Capítulo II: Aquisição de linguagem e aquisição de língua materna estudo das diferentes concepções e teorias de aquisição da linguagem e algumas considerações sobre a aquisição de língua materna, considerando-se as teorias mais recentes na área.

- Capítulo III: Aquisição ou aprendizagem de língua estrangeira estudo teórico a partir dos conceitos que diferenciam aquisição e aprendizagem, bem como da diferença conceitual entre língua estrangeira e segunda língua; estudo sobre as estratégias de aprendizagem e sobre os diferentes conceitos de competências necessárias ao aprendiz de língua estrangeira. 
- Capítulo IV: Os marcadores discursivos: uma perspectiva conversacional - abordagem sobre as diferentes correntes teóricas que estudam a conversação e que contribuem para a área da Análise da Conversação e para o estudo dos marcadores conversacionais. Este trabalho discorre sobre as várias perspectivas de análise dos marcadores conversacionais e a tendência atual das pesquisas na área.

- Capítulo V: Os marcadores conversacionais na interlíngua dos aprendizes de língua estrangeira - análise pormenorizada dos marcadores discursivos presentes na interlíngua de estudantes de espanhol no Brasil, sua freqüência, função e delimitação de padrões de comportamento para o seu uso no contexto conversacional e interativo.

- Considerações Finais: Discussão sobre os resultados obtidos, levando-se em conta os objetivos apontados e a constatação ou não da hipótese inicialmente formulada. 
CAPÍTULO I 


\section{A LÍNGUA FALADA}

\section{Reflexões sobre o conceito de língua/linguagem e fala}

Em seu curso de Lingüística Geral, na primeira década do século XX, Saussure $(1916)^{2}$ já afirmava que a língua (langue) é parte da linguagem, "um produto social da faculdade de linguagem e um conjunto de convenções necessárias, adotadas pelo corpo social para permitir o exercício dessa faculdade nos indivíduos", um princípio de classificação, adquirida e convencional e a diferenciava da fala (parole), como um ato individual de vontade e inteligência, no qual convém distinguir as combinações pelas quais o falante realiza o código da língua no propósito de exprimir seu pensamento pessoal e o mecanismo psicofísico que the permite exteriorizar essas combinações (op. cit., p. 22). Por sua vez, sublinha que "os signos da língua são, por assim dizer, tangíveis; a escrita pode fixá-los em imagens convencionais, ao passo que seria impossível fotografar em todos os seus pormenores os atos da fala...". (op. cit., p. 23). A linguagem é, para Saussure, a totalidade constituída pela língua e pela fala.

A teoria saussureana foi contestada por Coseriu (1967, p. 89) que considera que a língua e a fala fazem parte de um sistema lingüístico no qual a norma pode coincidir aparentemente com o sistema, assim como a realização individual pode coincidir com a norma, mas que não se pode deixar de distinguir os dois conceitos que se referem a distintos planos de abstração. A norma para Coseriu não se estabelece segundo critérios de correção e de valoração subjetiva do que se expressa, mas é aquela que seguimos por sermos membros de uma determinada comunidade lingüística; aquela que comprova como se diz e não como se deve dizer (op. cit., p. 90). Dessa forma, considera que se pode adotar "linguagem" como termo geral para indicar o conjunto dos seguintes conceitos:

\footnotetext{
2 SAUSSURE, Ferdinand. Curso de lingüística geral, ed. Charles Bally, Albert Sechehaye, e Albert Riedlinger, tradução de Antônio Chelini, José Paulo Paes e Izidoro Blikstein. São Paulo: Cultrix, 1997, originalmente publicado como Cours de linguistique générale. Paris: Payot, 1916.
} 
falar - acervo lingüístico ${ }^{3}$ - língua; considerando-se o fenômeno a partir de três pontos de vista: na sua realidade concreta (o falar concreto - ato lingüístico ou conjunto de atos lingüísticos); na sua virtualidade (aspectos psíquicos tais como: memória estratificada, generalizada e formalizada de atos lingüísticos reais) e como substrato do falar concreto; como abstração que se estrutura sobre a base dos atos lingüísticos concretos; e que a língua se comprova somente no falar. Estabelece, assim, as diferenças entre sistema, norma e fala ${ }^{4}$, e, conseqüentemente, a diferença entre língua e fala. Para Coseriu (op. cit., p. 101), a distinção se estabelece a partir das seguintes oposições:

1) Sistema e Representação - a língua compreende somente o sistema, e a fala todos os demais conceitos, envolvendo vários graus de abstração (normas sociais e individuais) e o plano concreto do falar.

2) Concreto e Abstrato - neste plano, a fala coincide com o falar e a língua compreende todos os demais conceitos principais, envolvendo vários graus de abstração (norma e sistema), que, entretanto, manifestam-se concretamente no falar.

\footnotetext{
${ }^{3}$ Considera o acervo lingüístico o saber que é condição do falar concreto.

4 "Em um primeiro grau de formalização essas estruturas são simplesmente normais e tradicionais na comunidade, constituem o que chamamos norma; mas em um plano de abstração mais alto, desprendem-se delas próprias uma série de elementos essenciais e indispensáveis, de oposições funcionais: ao que chamamos sistema" (COSERIU, 1967, p. 94), são formas que se comprovam no momento da fala, "abstrações que se elaboram sobre a base da atividade lingüística concreta, em relação com os modelos que ela utiliza" (op.cit., p. 95). Para o autor, a fala, por sua vez, representa os atos lingüísticos concretamente registrados no momento da sua própria produção, é a realização individual-concreta da norma, que contém a própria norma e, ademais, a originalidade expressiva dos indivíduos falantes (op.cit. p. 95-96). (Tradução nossa)
} 
3) Social e Individual - aqui a língua compreende o sistema e a norma, e a fala envolve a norma individual e o falar concreto, contendo, entretanto, os outros conceitos.

4) Novidade ou originalidade expressiva e Repetição - a fala compreende exclusivamente os atos de fala e a língua todos os demais conceitos, inclusive os aspectos sistemáticos e normais do falar.

\section{Uso, Norma e Sistema}

Dentro de uma perspectiva estruturalista, e mediante a concepção de que a língua é uma imagem acústica e, desta forma, passível de ser analisada enquanto a sua fonologia e morfologia, Saussure liga a língua a uma matéria dada e, portanto, a assimila à "norma". Afirma, ademais, que a língua é um conjunto de hábitos lingüísticos, e, conseqüentemente, não seria nada mais do que um "uso".

A fala seria, para o autor, um ato individual de vontade e inteligência, no qual podemos distinguir: 1) as combinações pelas quais o falante realiza o código da língua no propósito de exprimir seu pensamento pessoal; 2) o mecanismo psico-físico que the permite exteriorizar essas combinações. A fala seria a concretização fonética de uma infinidade de movimentos musculares extremamente difíceis de distinguir e representar (articulação dos sons).

Para Hjelmslev (1991, p. 84), a língua pode ser considerada como:

1) forma pura (língua-esquema): definida independentemente de sua realização social e de sua manifestação material;

2) forma material ( língua-norma): definida por uma dada realização social, mas ainda independente do detalhe da manifestação; 
3) conjunto dos hábitos adotados numa dada sociedade e definidos pelas manifestações observadas ( língua-uso).

A língua-esquema pode ser definida como algo realizável e não algo realizado. Deixa aberta toda e qualquer manifestação (fônica ou gráfica; gestos; sinais; códigos) sem, entretanto, afetar a definição de língua: ela se mantém idêntica a si mesma.

A língua-norma permite tantas línguas quantas forem as manifestações possíveis que tornem necessária uma definição diferente. Hjelmslev cita, como exemplo, a língua francesa. Aqui, o francês escrito seria uma outra língua em relação ao francês falado; o francês operado por meio do alfabeto Morse seria uma outra língua em relação ao francês operado por meio do alfabeto latino, e assim por diante.

A língua-uso compreende, por exemplo, todas as qualidades encontradas na pronúncia habitual de uma língua, fixando-a, assim, como elemento da língua tida como uso. Deixa por conta da improvisação ocasional a possibilidade de variar a pronúncia no interior dos limites prescritos pela definição. E, ainda assim, permanece a mesma.

Hjelmslev admite que a concepção de língua-esquema é a que mais se aproxima da concepção saussuriana, uma vez que é a que constitui a máxima fundamental de Saussure quando este afirma que a língua é uma forma, não uma substância. Contudo, para o autor, do ponto de vista da fala, faz-se necessário considerar a norma, o uso e o esquema e, desta forma, compreende a importância de se fazer uma analogia de estrutura entre os dois planos da língua: o do conteúdo e o da expressão. A norma, para ele, determina o uso e o ato, e não inversamente. A norma nasceu do uso e do ato. $\mathrm{O}$ uso e o ato se pressupõem mutuamente; portanto, há interdependência. Já o esquema é determinado, pressuposto tanto pelo ato quanto pela norma, e não inversamente. Norma, uso e 
ato estão interligados e tendem naturalmente a não constituir senão o objeto verdadeiro, a saber:

(...) o uso, em relação ao qual a norma é a abstração, e ato uma concretização. É unicamente o uso que constitui o objeto da teoria da execução; a norma, na realidade, nada mais é que uma construção artificial, e o ato, por sua vez, é apenas um documento passageiro. (HJELMSLEV, 1991, p. 92)

Para a realização do esquema (sistema), seria necessário um uso coletivo e individual e, conseqüentemente, não haveria como distinguir entre o social e o individual. O mesmo aconteceria com o ato. Por sua vez, o uso seria um conjunto de possibilidades entre as quais qualquer ato teria livre escolha. E conclui o autor: "por definição nada pode haver no ato que não seja previsto pelo uso" e "a norma, pelo contrário, é apenas uma abstração tirada do uso por um artifício de método" (op. cit., p. 92).

Para Coseriu (1967, p. 94), "norma" seriam os modelos, formas ideais que o falante encontra para a expressão de suas intuições inéditas que se encontram no que chama de "língua anterior". Os atos lingüísticos são atos de criação inédita embora sejam, ao mesmo tempo, atos de re-criação, uma vez que se estruturam sobre modelos precedentes, os quais estão presentes nos novos atos, ao mesmo tempo em que os superam. Em um primeiro momento de formalização, sublinha o autor, essas estruturas são simplesmente normais e tradicionais na comunidade seria a "norma" e, em um plano de abstração mais alto, desprendem-se delas uma série de elementos essenciais e indispensáveis, de oposições funcionais, formando o que se denomina "sistema". Norma e sistema não são, para o autor, realidades autônomas e opostas durante o ato de fala, nem mesmo "aspectos do falar". São formas que se comprovam no mesmo falar, abstrações que se elaboram sobre a base da atividade lingüística concreta, em relação aos modelos que ela utiliza. A norma é variável, segundo os limites e a índole da comunidade, entretanto, pode haver também uma norma individual, se consideramos os atos lingüísticos de um só indivíduo, desde que se considere nela tudo o que é 
repetição, elemento constante no falar do indivíduo, tudo o que é originalidade expressiva absoluta, elemento totalmente inédito; eliminando-se somente aquilo que seja ocasional e momentâneo.

No entanto, Leite $(1998$, p. 180) chama a atenção para a diferença entre "norma e uso lingüísticos" a partir de três perspectivas possíveis de sua análise :

1) Lingüística: "a norma é aquilo que já se realizou e, teoricamente, sempre se realizará no grupo social; é a tradição à qual todos estão submetidos e obedecem, sem sentir. A qualquer tentativa de ruptura dessa tradição, há reação".

2) Pragmática: a norma se dividiria em três:

a) norma objetiva: "segundo a qual entendemos que cada grupo tem sua própria norma e que, conseqüentemente, há tantas normas quantos grupos sociais houver".

b) norma prescritiva: "cujo objetivo é o de impor um uso extraído da língua literária de épocas sempre anteriores à dos falantes contemporâneos" e, por estar codificada e ser a de maior prestígio dentro da comunidade lingüística, "é a única que se presta à realização dos objetivos políticopedagógicos da escola".

c) norma subjetiva: que é "o ideal de língua a que todos os falantes aspiram".

3) Sócio-antropológica: aqui, também se pode dividir a norma em duas: 
a) norma explícita: "codificada e divulgada por um aparelho de referência, integrado pela escola, gramáticas e dicionários";

b) norma implícita: "próprias de cada grupo social e, na medida do possível tão mutáveis quanto estes".

A autora opta, portanto, por definir 'norma' como "o resultado do uso lingüístico de um dado segmento social e esse 'uso', por tradicional, é preservado e varia de acordo com as possibilidades de realização que o usuário faz da língua" que, consiste, portanto, em uma norma implícita a um grupo social distinguindo-se da norma do "bom uso", que seria aquela posta na gramática tradicional - ou norma explícita (op. cit., p. 180-181). Nesta trajetória, depreende-se que uso e norma lingüísticos estão diretamente relacionados à situação sócio-interacional e é ela quem define a escolha dos itens lexicais e sintáticos para a formulação do enunciado por parte dos falantes (op. cit., p. 179).

\section{Contribuições da Pragmática e da Análise da Conversação}

O conceito de norma implica a existência de atos lingüísticos que, amplamente estudados por Coseriu, ganharam ainda maior destaque com os estudos sobre enunciação no início dos anos 60.

Os atos lingüísticos ou atos de fala passam então a ser um dos temas mais discutidos na pragmática que, ao contrário de defender que a Lingüística estuda a linguagem menos a fala, de acordo com a teoria saussureana, defende a não centralidade da língua em relação à fala (PINTO, 2001, p. 48) e, portanto, estuda a linguagem, ou seja, a língua associada a sua produção. 
Considerado o precursor da pragmática moderna, Austin (1962) fundamentou a teoria dos atos de fala e iniciou uma nova etapa nos estudos da linguagem, em que esta não é mais vista somente para descrever o mundo, mas sim para fazer coisas. Posteriormente, Grice, em seu trabalho "Logic and Conversation", de 1967, estabelece, a partir da teoria dos atos de fala, quatro máximas $^{6}$, a saber: de quantidade, de qualidade, de relevância e de modalidade, que regeriam o Princípio de Cooperação, princípio este que requer dos interlocutores uma contribuição mútua na conversação, adequando-a a um propósito e em uma direção determinados.

Tais estudos deram origem aos trabalhos no campo da Análise da Conversação que têm contribuído justamente para investigar ainda mais os elementos envolvidos na interação humana, bem como os recursos e estratégias utilizados pelos falantes para que haja uma perfeita harmonia e compreensão sobre as relações sociais.

As relações sociais, por sua vez, já vinham sendo estudadas pela Sociolingüística que apontou a interdependência entre língua e sociedade (HYMES, 1972, p. 35-71). O estudo etnográfico da fala e posteriormente da comunicação, desenvolvido pelo autor, envolveu projetos de diversidade e variação lingüística colhendo dados que possibilitaram a análise das atitudes dos falantes dentro de contextos específicos, bem como determinar padrões locais próprios para a atividade de fala e, nesse sentido, "a língua passa a ser vista situada no fluxo e padrões dos eventos comunicativos" (op. cit., p. 35-71).

Preti (1994, p. 45) discorre sobre o fato de que para entendermos o

\footnotetext{
${ }^{5}$ Publicado pela primeira vez em 1975, em Syntax and Semantics, vol. 3, por P. Cole and J. Morgan (ed.) e vol. 9, por P. Cole (Ed.), Nova York. Academic Press, 1975, 1978. Neste trabalho, utilizamos a edição de 1989, publicada em Studies in the way of words, pela Harvard University Press.

${ }^{6}$ Máxima de Quantidade: fazer a sua contribuição tão informativa quanto for necessária; não fazer da sua contribuição mais informativa do que seja necessário. Máxima de Qualidade: não diga o que você acredita ser falso; não diga nada que careça de evidências. Máxima de Relevância: seja relevante. Máxima de Modalidade: evite a obscuridade; evite a ambigüidade; seja breve, seja metódico. (Tradução nossa).
} 
conceito de "usos ou normas lingüísticas", devemos lembrar que "cada falante atua de acordo com certos comportamentos lingüísticos constantes na comunidade em que vive e que são eleitos como ideais para comunicar e transmitir as informações necessárias nos vários momentos de sua vida em comum". Ainda acrescenta que esses "hábitos lingüísticos coletivos" estão em constante, mas lenta, renovação e que ganham força, gradativamente, através das convenções admitidas, estabelecidas e conservadas através das gerações.

Esse autor defende a idéia de que o "uso" não é arbitrário dentro da sociedade. Ao contrário, é sempre determinado pelo interesse da comunidade que sente a necessidade de ser compreendida. A "norma" seria o ponto de chegada no processo de uniformização e nivelamento da língua. Segundo Preti (op. cit.,p. 45) "a própria sociedade se encarrega de preservar o uso, que ela própria estabeleceu" e que, em tese, "a acomodação do indivíduo a uma "norma lingüística' pode levá-lo a um condicionamento na própria articulação de seus pensamentos e, de certa forma, a um condicionamento do seu próprio pensamento". Corrobora, portanto, a afirmação de Mattoso Câmara Jr. (1986, p. 9): "é pela posse e pelo uso da linguagem, falando oralmente ao próximo ou mentalmente a nós mesmos, que conseguimos organizar o nosso pensamento e torná-lo articulado, concatenado e nítido..."

\section{Considerações sobre língua, linguagem e fala}

Em linhas gerais, podemos considerar que a linguagem se caracteriza por:

- Ser multiforme e heteróclita;

- Ser física, fisiológica e psíquica ao mesmo tempo;

- Pertencer ao domínio individual e ao domínio social;

- Ser uma capacidade natural dos seres humanos;

- Ser heterogênea. 
Por sua vez a língua representa:

- Uma parte determinada e essencial da linguagem;

- Um produto social da faculdade de linguagem e um conjunto de convenções necessárias, adotadas pelo corpo social para permitir o exercício dessa faculdade nos indivíduos;

- Algo adquirido e convencional;

- Um sistema de signos em que somente existe a união do sentido e da imagem acústica e as partes do signo são igualmente psíquicas, conferindo-lhe uma natureza homogênea;

- Um produto que o indivíduo registra passivamente, não supõe premeditação;

- Parte social da linguagem, exterior ao indivíduo que, por si, não pode nem criá-la nem modificá-la;

Por essas características, a língua não existe senão em virtude de uma espécie de contrato estabelecido entre os membros da comunidade, mas necessita ser aprendida para colocá-la em funcionamento. No entanto, os signos de uma língua são tangíveis, ou seja, a escrita pode fixá-los em imagens convencionais.

Finalmente, a fala é um ato individual de vontade e inteligência e depende de um mecanismo psicofísico que permite ao falante exteriorizar uma série de combinações através das quais os falantes realizam o código da língua para exprimir seu pensamento pessoal. 
Essas combinações se expressam por intermédio de atos de fala que, depois das teorias da enunciação discutidas por Bakhtin-Volochínov (1929); Austin (1962) e Benveniste (1974), são hoje consideradas unidades de ação, informativas e que respondem à intenção comunicativa dos falantes (BRIZGÓMEZ, 1998; GALLARDO-PAÚLS, 1998).

A teoria dos atos de fala de Austin parte da premissa de que o falante nem sempre fala o que quer dizer e não pode dizer exatamente o que quer dizer em cada emissão. Austin (1962) afirma que os falantes podem fazer muitas coisas distintas com as palavras e que distintas emissões não são afirmações nem perguntas sobre determinada informação, mas ações; e corrobora Stubbs (1983, p. 151) quando acrescenta à essa idéia a informação de que a quantidade de sentido indireto implicada no discurso é um grande problema para a análise, pois há uma distância entre o que se diz e o que se quer dizer, além do que há muitas camadas de significado entre o significado proposicional literal de uma emissão e o ato que concretiza no contexto. Para Alcaraz e Martínez-Linares (1997, p. 14), o conjunto das teorias dos atos de fala representa um marco na pragmática por examinar com clareza e precisão as relações existentes entre os signos e os seus usuários.

A fala sempre vem antes da língua, entretanto, a língua é necessária para que a fala seja inteligível e produza todos os seus efeitos, bem como a fala é necessária para que a língua se estabeleça. Dessa maneira, língua e fala são interdependentes, ou seja, a língua é, ao mesmo tempo, instrumento e produto da fala. Fala e língua compõem a linguagem humana que, influenciada pelos eventos sociais e culturais das comunidades, confere ao homem a capacidade de comunicar-se e expressar seus pensamentos, de interagir com o outro e estabelecer relações e vínculos sociais que o diferem de outros animais, bem como, cognitiva e psicologicamente capazes de evoluir continuamente. 
CAPÍTULO II 


\section{AQUISIÇÃO DE LINGUAGEM E AQUISIÇÃO DE LÍNGUA MATERNA}

\section{As diferentes concepções de linguagem e suas áreas de estudo}

Os estudos sobre língua e fala iniciados por Saussure marcaram uma longa e produtiva trajetória no campo das pesquisas sobre linguagem. Enquanto na teoria saussuriana a linguagem encerra a língua e a fala, os trabalhos posteriores aos seus apontaram para horizontes que mostravam que não se poderia analisar a linguagem meramente do seu ponto de vista fonológico e morfológico, mas que outros elementos contribuíam para essa capacidade tão complexa do ser humano.

Embora o estudos sobre a linguagem datam de até oito séculos a.C., sobretudo entre gregos e latinos, foi somente no século XX que ganhou um forte interesse. A Lingüística tem-se, desde então, constituído uma área de forte produção acadêmica em estudos da linguagem, sobretudo de processos cognitivos, ao lado da filosofia e psicologia.

Na metade do século passado, os trabalhos de Noam Chomsky trouxeram novas perspectivas às pesquisas desenvolvidas, sobretudo na área da lingüística estrutural e da pragmática, alterando definitivamente os conceitos existentes sobre linguagem. A chamada teoria gerativista de Chomsky contribuiu fortemente para o desenvolvimento das pesquisas na área da aquisição de linguagem. Pela primeira vez, surgia a idéia de uma linguagem e gramática universais da língua, através da qual todos os seres humanos são capazes de desenvolver a linguagem de forma inata, o que, segundo sua teoria, explicaria o fato de que até os três anos de idade as crianças já se expressam com fluência e uma certa correção lingüística, sem que tenham que passar por uma aprendizagem formal.

A lingüística estrutural e a lingüística gerativista descrevem a língua enquanto sistema abstrato, sem se preocupar com as características individuais e 
fora de qualquer contexto. Em contrapartida, muitos lingüistas, filósofos e psicólogos começaram a se dedicar ao que chamaram de linguagem como atividade, ou "língua como ação", em que os aspectos sociais e culturais são relevantes e as relações entre os seus usuários são determinantes para as ações que se realizam em e para a linguagem. Nasce a lingüística pragmática, em que Austin foi o grande precursor.

Posteriormente, a Análise do Discurso, apoiada nos estudos sociolingüísticos e etnográficos, difundiu-se amplamente guiada pela intenção de estudar a organização da linguagem além da oração e da frase, em outras palavras, estudar unidades lingüísticas maiores, como conversações ou textos escritos. Buscou analisar o uso da linguagem em contextos sociais, observando a interação ou o diálogo entre os falantes. Este campo de estudos deriva da compreensão de que a linguagem, a ação e o conhecimento são inseparáveis e, conseqüentemente, a linguagem e a situação também o são. Para Stubbs (1983, p. 17), no âmbito da inseparabilidade da linguagem e situação, normalmente conseguimos saber que tipo de linguagem se pode esperar em diferentes situações sociais e, inversamente, é possível reconstruir com bastante exatidão a situação social em que se produziu um determinado fragmento de linguagem. Outrossim, segundo o autor (op. cit., p. 31), os princípios que regem a Análise do Discurso subjazem ao reconhecimento da coerência textual mesmo em situações espontâneas de fala ou de texto escrito.

Assim posto, podemos traçar algumas diferentes concepções para a linguagem:

1. como representação do mundo e do pensamento: o homem representa para si o mundo por intermédio da linguagem e, dessa forma, a função da língua é representar seu pensamento e seu conhecimento de mundo. (MATTOSO CÂMARA JR, 1961; PRETI, 1994); 
2. como instrumento de comunicação: a língua é vista como um código mediante o qual um emissor comunica a um receptor determinadas mensagens. A principal função da linguagem é, neste caso, a transmissão de informações (JAKOBSON, 1969)

3. como forma (ou lugar) de ação ou interação: a linguagem é vista como atividade, como forma de ação, ação inter-pessoal com uma finalidade orientada; como lugar de interação que possibilita aos membros de uma sociedade a prática dos mais diversos tipos de atos, que irão exigir dos semelhantes reações e/ou comportamentos e que estabelecem vínculos e compromissos que antes não existiam. Isso significa que há a necessidade de constante negociação entre os interlocutores, cujas regras são estabelecidas no momento da interação (STUBBS, 1983).

\section{Principais estudos sobre aquisição de linguagem}

O termo aquisição de linguagem pode ser entendido sob dois aspectos: em sentido amplo, que se refere ao desenvolvimento de habilidades de expressão e de interação social por meio de uma língua, ou mesmo à própria constituição da criança como sujeito da fala por intermédio de uma língua em aquisição; em sentido estrito, quando se estuda a aquisição de uma dada língua como língua materna, no que concerne ao que esta tem de específico ao relacionar seqüências de sons vocais a uma entidade semântica (CORRÊA, 2006, p. 22).

Num trabalho recente de retrospectiva sobre os estudos de aquisição de linguagem, Corrêa (1999, p. 349) ressalta diferentes perspectivas e abordagens para o estudo da aquisição da linguagem, tais como:

a) a proposta inatista da Teoria Lingüística versus as diferentes posturas em relação ao quanto de especificidade é necessário atribuir à 
língua/gem quando comparada a outros sistemas cognitivos e ao quanto de independência pode ser atribuída ao desenvolvimento lingüístico no conjunto do desenvolvimento cognitivo;

b) a centralização dos problemas da aquisição da linguagem em seu aspecto sintático versus a preocupação com os conceitos e relações semânticas expressas na fala da criança e a hipótese de uma precedência da semântica sobre a sintaxe, no processo de aquisição;

c) idéia de precariedade do input lingüístico da criança versus a caracterização da fala dirigida à criança como um registro peculiar;

d) o desenvolvimento lingüístico tomando forma a partir da discriminação do sinal acústico da fala nos primeiros dias de vida versus o desenvolvimento lingüístico visto como fundado em habilidades comunicativas ou pragmáticas pré-lingüísticas.

O estudo da aquisição da linguagem permeia, portanto, várias áreas do conhecimento e teve seu início por volta dos anos 30 na psicologia com estudos importantes desenvolvidos por Piaget e Vygotsky (Teoria Cognitivista). O primeiro, com a Teoria Genética, sobre lógica e pensamento; e o segundo, com a Teoria Sociocultural, em que defende que os processos de aprendizagem e desenvolvimento se influenciam entre si (Cf. GUZMÁN e ROJAS, 1993) e que a aquisição de linguagem não difere de nenhum outro aprendizado (Cf. MARTíNMARTíN, 2004). Para Piaget (1993), o pensamento é anterior à linguagem, uma vez que a fonte do conhecimento é a ação e, dessa forma, existe uma interiorização desde o primeiro estágio de aprendizagem. Para Vigotsky (1988), o desenvolvimento da linguagem converge com o pensamento, ou seja, um não é anterior ao outro, na verdade, são indissociáveis. Ao mesmo tempo, o autor defende que 0 desenvolvimento envolve um processo crescente de amadurecimento e construção permanente do conhecimento. $\mathrm{Na}$ área da 
psicologia, ainda encontramos Skinner (1957) com a sua teoria do estímuloresposta-reforço.

Posteriormente, as pesquisas encontraram campo fértil na lingüística, com os estudos de aquisição de léxico, pragmática, análise do discurso, lingüística matemática e fonética acústica - como por exemplo, Halliday (1973), que embora sendo cognitivista, ressalta a importância dos fatores sociolingüísticos na aquisição da linguagem.

Não obstante, esses estudos foram incrementados, sobretudo, a partir da Lingüística Gerativista (CHOMSKY, 1959), e sua tese de que as crianças não aprendem por imitação e que o ser humano já nasce dotado de um dispositivo de aquisição de linguagem, que é distinto da capacidade de processar o pensamento em geral e que faz com que as crianças passem pelas mesmas etapas de desenvolvimento de suas capacidades lingüísticas e, a partir da concepção de que o input não é suficiente para explicar a rápida e perfeita aquisição de língua materna, desenvolve a sua teoria sobre uma Gramática Universal. O entendimento de que existe uma Gramática Universal da língua materna, estimulou, no final dos anos 90, um grupo de pesquisadores do campo da fonética e fonologia a apresentarem estudos sobre a possibilidade de existir, também, uma Fonética Universal que promoveria o desenvolvimento do léxico a partir da concepção de bootstrapping da língua.

O termo bootstrapping tem sido utilizado para designar um problema de desencadeamento ou de inicialização, quando se discute o que vem antes no desenvolvimento da aquisição da linguagem: é certo que os bebês têm que aprender aspectos relevantes da fonologia, do léxico ou da sintaxe da sua língua materna (GOUT; CHRISTOPHE, 2006, p. 103), mas o que vem antes? Uma grande discussão se faz em torno da concepção de que a prosódia desencadeia o aprendizado do léxico e de que os bebês precisam ter acesso a palavras e seus significados para aprender o que se faz necessário sobre a sintaxe da língua (SCARPA, 1999, GOUT; CHRISTOPHE, 2006). 
Entretanto, pesquisas na área têm demonstrado que a aquisição do léxico não é tão fácil quando a criança é exposta às palavras; parece ser decisivo que o maior desempenho ocorra quando inseridas numa estrutura sintática.

Segundo Gout e Christophe (2006, p. 103), isso leva a uma circularidade potencial: à primeira vista, parece que o léxico é necessário à aquisição da sintaxe e que a sintaxe é necessária à aquisição do léxico, o que configura, portanto, o problema de bootstrapping da língua.

Atualmente, os estudos mais recentes estão sendo desenvolvidos nas áreas da psicologia - que envolvem estudos de Psicologia Cognitiva, Psicolingüística e Psicologia do Desenvolvimento (incluindo casos de patologia de linguagem, como os estudos de afasias desenvolvidos tanto pela Lingüística como pela Fonoaudiologia) e pelos modernos trabalhos em Neurolingüística, em que o cérebro está sendo mapeado e analisado por meio de sinais eletromagnéticos.

A linguagem é hoje foco de pesquisa de muitas áreas do conhecimento, entretanto, como afirma Corrêa (2006), os resultados ainda não convergem de modo a conciliar as distintas áreas e conhecimentos, desenvolvendo-se de forma essencialmente autônoma.

No Brasil, os estudos pioneiros de Claudia Lemos, a partir de meados da década de 70, deram origem a um projeto de Aquisição da Linguagem, mas ainda estamos longe de resolver as controvérsias existentes na área, quais sejam: questões relativas à aquisição de uma determinada língua, ao desenvolvimento de habilidades de processamento lingüístico e ainda a formas de expressão dependentes de uma linguagem verbal (CORRÊA, 1999, p. 350); ressaltadas ainda mais pelo caráter interdisciplinar em que tais estudos hoje se encerram. Corrêa (op. cit., p. 350) comenta que as pesquisas deverão se desenvolver cada vez mais no nosso país à medida que estas questões forem sendo discutidas. 


\section{Aquisição de Língua Materna: algumas considerações}

$\mathrm{Na}$ concepção de Saussure (op. cit. p. 17), a língua é uma parte determinada e essencial da linguagem, ao mesmo tempo em que é um produto social da faculdade de linguagem e um conjunto de convenções necessárias, adotadas pelo corpo social para permitir o exercício dessa faculdade nos indivíduos. A língua constitui, portanto, um conjunto de signos; algo adquirido e convencional numa sociedade. É o produto que o indivíduo registra passivamente, sem premeditação. Na língua existe somente a imagem acústica que pode traduzir-se numa imagem visual constante (escrita) e ela existe em virtude de uma espécie de contrato estabelecido entre os membros da comunidade. Mesmo que o homem seja privado do uso da fala, conserva a língua, contanto que compreenda os signos vocais que ouve.

A criança precisa apresentar condições físicas perfeitas para emitir e receber sinais sonoros na língua. Estudos realizados por Yule (1985, p. 176) mostram que a simples exposição ao som (por exemplo, rádio e TV) não é suficiente para que uma criança aprenda a língua materna, ou a língua do seu meio. Além disso, ainda de acordo com o autor, os seguintes requisitos também são básicos para a aquisição da primeira língua: a criança nos dois ou três primeiros anos de vida necessita interagir com outros usuários da língua no sentido de colocar a faculdade de linguagem em operação com uma língua em particular; a transmissão cultural é importante, ou seja, a língua que a criança aprende não é geneticamente herdada, mas adquirida em um meio-ambiente de uso da língua muito particular.

A aquisição da primeira língua é marcada pela velocidade com que ela se processa e, quando a criança ingressa na escola fundamental, ela já é um falante sofisticado do idioma, capaz de comunicar-se com outras crianças e adultos. Entretanto, para que isso seja possível, é necessário que a criança tenha sempre um interlocutor, pois nos primeiros anos dependerá dos modelos que tiver em seu meio-ambiente. 
Para a identificação entre a criança e seus pais, por exemplo, os elementos extra-lingüísticos como os gestos, o silêncio, a musicalidade, as expressões faciais também são fatores preponderantes na aquisição da linguagem verbal.

Segundo Derdyk (1994, p. 110), a imitação de certas atividades e movimentos é um dos recursos utilizados pela criança e decorre da vontade de reproduzir a operação, bem como da necessidade de se apropriar e participar, gerando, assim, uma forma de afirmação de sua identidade.

Um aspecto importante na identificação com os pais, comentam Hilgard \& Atkinson (1979, p. 85) é o fato de que a criança aceita os modelos de conduta, de forma que aprende como reagir frente a outras pessoas, por meio de modelos aceitos sobre o que é bom e adequado, e resistem à tentação de transgredir as regras de comportamento aceitáveis. Ao expressar-se, as crianças o fazem para alguém, ao que Derdyk (op. cit., p. 99) denomina "sujeito ativo" e "sujeito passivo", respectivamente. Isso ocorre devido ao desejo da criança em ingressar no mundo adulto e, portanto, o desejo de estabelecer uma comunicação que ao final se realiza.

Podemos observar que as crianças, desde o seu nascimento, passam por fases não verbais de desenvolvimento - desde os risos, choros, movimentos de mãos e pés, pequenos gritos até a emissão das primeiras sílabas, como ma-ma, pa-pa e, finalmente, as primeiras palavras. A partir daí, ingressam definitivamente no mundo da fala, do código lingüístico imposto pela comunidade em que crescem, o que chamamos aqui de língua materna.

$\mathrm{Na}$ trajetória da aquisição da língua materna, os elementos pragmáticos estão inseridos no cotidiano da criança desde os primeiros anos de sua vida, como já o apontamos, e isso se desenvolve mediante a observação do universo em que vive - universo este em que estão presentes os aspectos afetivos, socioculturais e psicológicos. De acordo com Derdyk (op. cit., p. 96), a aquisição da fala propicia uma nova relação da criança com o universo, com os objetos, as 
situações e os seres; a palavra passa a ser um instrumento poderoso por meio do qual ela poderá administrar seus medos, angústias, emoções e desejos. Isso explica o fato de que muito cedo, a partir dos dezoito meses de vida, as crianças são capazes de usar alguns verbos no imperativo ou no presente do indicativo.

Seja para expressar seus desejos ou emoções, o uso dessas formas verbais surgem antes mesmo da aprendizagem da sintaxe da língua e da elaboração de estruturas lingüísticas mais sofisticadas.

Yule (1985) salienta que a velocidade da aquisição associada ao fato de que isso sempre ocorre, sem instrução evidente e indiferentemente a grandes variações no âmbito de fatores socioculturais, tem levado à hipótese de que há uma predisposição "inata" na criança para adquirir a linguagem e que podemos pensar nisso como a faculdade de linguagem do homem com a qual as crianças recém-nascidas já são dotadas.

O conceito de faculdade de linguagem foi empregado por Chomsky, que defende a teoria de uma Gramática Universal. Lemle (2006, p. 1-2) sintetiza o trabalho do pesquisador norte-americano esclarecendo que a faculdade de linguagem é considerada por Chomsky um "órgão da mente" (Language Organ) tal como o sistema visual, o aparelho digestivo e outros órgãos que compõem o sistema orgânico do ser humano, decorrente, portanto de um produto da genética. Esse sistema é altamente complexo e subdividido em partes, tais como: fonologia, sintaxe, semântica, pragmática e que, por um mecanismo de aquisição de linguagem, a criança exposta à língua falada ao seu redor é capaz de interpretar os dados lingüísticos e deduzir a gramática da língua particular da sua comunidade - isso é o que Chomsky denomina Gramática Universal, que gera expressões possíveis na língua e, por esse motivo, denominada Gramática Gerativa.

Várias linhas teóricas coexistem no tocante à concepção de uma Gramática ou Fonética Universais. Scarpa (1999, p. 253), por exemplo, sublinha que não há 
evidencias de uma prosódia universal, posto que a fala "prelingüística" dos bebês se caracteriza por estruturas que estão longe de estar organizadas e feitas, entretanto, já exibe um trabalho de busca do estruturado e do simbólico, que, portanto, se distancia da "naturalidade" amorfa sem significante nem significado.

Por outro lado, as pesquisas mais atuais na área de aquisição de língua materna são aquelas que envolvem testes laboratoriais com sensores eletrônicos e tomografia das regiões cerebrais ativadas por estímulos provocados. Elas têm aberto uma série de hipóteses sobre como se processaria esse fenômeno.

Kuhl (2000), por exemplo, discute sobre duas teorias que marcaram a maioria dos estudos existentes na área: a de Skinner, que propunha que as crianças aprendem uma língua através do monitoramento e gerenciamento de eventos bem sucedidos; e a de Chomsky, que sugeriu uma faculdade de linguagem que incluía controles inativos específicos nas formas possíveis que a linguagem humana poderia ter. Em outras palavras, Chomsky defendeu a teoria de uma gramática e fonética universais, inatas.

A autora propõe, entretanto, uma nova teoria sobre a aquisição da linguagem, baseando-se no que denomina "Native Language Magnet Model" (modelo do campo magnético da língua nativa ${ }^{7}$ ), observada em testes laboratoriais a partir do magnetismo cerebral produzido durante a audição de protótipos fonéticos.

Os estudos nesse campo mostram que determinadas áreas do cérebro se tornam marcadas quando se submete a criança à linguagem ambiente - ocorre uma espécie de mapeamento cerebral - e isso parece representar um novo tipo de aprendizagem no qual o input da linguagem pode ser observado em detalhes pelo mapa que se configura através dessas zonas demarcadas. Essa "sensibilização" sofrida mediante a exposição à língua ambiente, cria uma espécie de filtro perceptivo para a primeira língua que a criança aprende, filtro este que dificulta a 
aprendizagem de uma segunda língua. Os resultados de sua investigação sugerem que não existe uma gramática ou fonética universais, senão desvios ou estratégias inatas que dão lugar a controles de percepção e aprendizagem e que permitem que as crianças recuperem do input da linguagem regras pelas quais as pessoas de sua comunidade se comunicam.

O trabalho de Kuhl indica ainda que a percepção das unidades de fala não implica a priori conhecimento das próprias unidades fonéticas, senão a capacidade de detectar diferenças entre elas, que seriam, inclusive, comparadas de forma muito interessante. Por outro lado, durante a evolução da linguagem, os mecanismos de processamento da percepção auditiva detectam diferenças acústicas que influenciam a seleção das unidades fonéticas usadas na linguagem. Dessa forma, exploram-se características auditivas particulares durante a evolução do sistema sonoro usado na linguagem. A partir dessa observação, a autora afirma que se pode explicar o porquê de os japoneses não conseguirem diferenciar /// de /r/ ou, no caso dos falantes nativos de espanhol, a impossibilidade de reconhecer as vogais abertas do português (Cf. GONÇALVES, 2000).

Em sua pesquisa, Kuhl sustenta a idéia de que os mecanismos de domínio geral são responsáveis pela divisão inicial das unidades fonéticas da linguagem em crianças e, por isso, determinadas manifestações orais das mães (por exemplo, quando a mãe diz ao seu filho a palavra "mamãe", enfatiza a primeira sílaba MA), desencadeiam reações físicas nos bebês de poucos meses de idade e funcionam como um gatilho para que, posteriormente, ao pronunciarem as primeiras sílabas, consigam reproduzir exatamente aquele protótipo silábico repetido várias vezes por sua mãe.

Nesse sentido, parece que o cérebro dos bebês consegue detectar padrões do input da linguagem e usar informações distribucionais e probabilísticas contidas na linguagem ambiente para conseguir identificar unidades superiores. Quando isso ocorre, a imagem no mapa magnético do cérebro fica literalmente distorcida,

\footnotetext{
7 Tradução nossa
} 
o que significa que a percepção dos bebês se altera pela experiência, para que sua percepção de linguagem melhore.

Scarpa (1999, p. 253) sublinha, por sua vez, que não há evidências de uma prosódia universal, posto que a fala "prelingüística" dos bebês se caracteriza por estruturas que estão longe de estar organizadas e feitas; entretanto, já exibe um trabalho de busca do estruturado e do simbólico que, portanto, se distancia da "naturalidade" amorfa sem significante nem significado.

Tanto Scarpa como Kuhl sugerem, assim, que o reconhecimento prosódico origina, ou pelo menos facilita, a posteriori, o reconhecimento das unidades fonéticas da língua nativa.

Dentro da perspectiva de que a aquisição da língua/gem se dá pela composição de elementos lingüísticos, sociais e psicológicos, inclusive sendo difícil avaliar em que conjugação desses elementos ela se processa (fonético/lexical; lexical/gramatical etc.), é de senso comum entre os estudiosos da linguagem que é de fundamental importância nos primeiros anos da criança o típico e permanente diálogo travado entre ela e a mãe.

O motherese ou caretaker speech - modo de falar com os bebês através de encontros silábicos (mamã), diminutivos, frases interrogativas, entoações exageradas, repetições - constitui a primeira e crucial forma de interação entre o bebê e os adultos. O tipo de estrutura conversacional construída através desse tipo de fala (caretaker speech) parece conferir que a criança apresenta um conjunto de regras interativas antes mesmo de que ela se transforme em um falante participativo, comenta Yule (1985, p. 178), quem acrescenta que esse modo de falar 
(...) é também caracterizado por estruturas de sentenças simples e muita repetição. Se a criança ainda está em processo de resolver o sistema colocando sons e palavras juntas, então estes modelos simplificados produzidos através da interação com 0 adulto podem servir como boas indicações para as estruturas organizacionais básicas envolvidas. Além disso, em geral se observa que a fala dessas interações regulares com crianças mudam e se transformam em falas mais elaboradas à medida que a criança usa a linguagem. ${ }^{8}$

Em outras palavras, nessa fase denominada de "pré-linguagem" (YULE, op. cit., p. 178), o uso constante da língua leva ao seu aprimoramento. Vários estágios subseqüentes foram identificados por Yule, como o estágio holofrástico (estágio em que está presente uma única palavra); o estágio em que estão presentes duas palavras; o estágio de fala telegráfica; estágio de incorporação de morfemas - denominado estágio morfológico, seguido pelo sintático e semântico.

Aos cinco anos a criança estará ainda em processo de aquisição, no entanto, já apresentará grande parte dos elementos básicos da língua e já será um falante bastante competente do seu idioma.

Associado ao fato de percepção e produção se relacionarem, Kuhl (2000) analisou a fala a partir do motherese e concluiu que esse procedimento é bastante instrutivo e ajuda a criança na diferenciação das unidades fonéticas. As modificações feitas inconscientemente pelos adultos, quando estes falam com as crianças, representam um importante papel para o mapeamento do input da língua materna, sugerindo que o comportamento das pessoas mais velhas cumpre uma função importante também no processo de aquisição de linguagem. Dessa forma, quanto maior o input nessa fase, quanto mais estimuladas forem as crianças, mais cedo elas começam a falar e, segundo Papalia \& Olms (1998), quando ouvem sentenças complexas, descobrem as regras gramaticais com mais freqüência e de formas diferentes daquelas crianças que não são expostas na mesma proporção.

\footnotetext{
${ }^{8}$ Tradução nossa do original: (...) is also characterized by simple sentence structures and a lot of repetition. If the child is indeed in the process of working out a system of putting sounds and words together, then these simplified models produced by the interacting adult may serve as good clues to the basic structural organization involved. Moreover, it has generally been observed that the speech of those regularly interacting with children changes and becomes more elaborate as the child begins using more and more language.
} 
$\mathrm{Na}$ relação adulto-criança durante o processo de aquisição da língua, Lemos (2003, p. 16) discute sobre as mudanças que qualificam a trajetória da criança de infans a sujeito-falante e assinala que são mudanças que não representam a superação, mas sim uma relação entre três distintas posições:

(...) na primeira posição, pela dominância da fala do outro; na segunda posição, pela dominância do funcionamento da língua e, na terceira posição, pela dominância da relação do sujeito com sua própria fala. É na terceira posição que a criança enquanto sujeito falante se divide entre aquele que fala e aquele que escuta sua própria fala, sendo capaz de retomá-la, reformulá-la e reconhecer a diferença entre sua fala e a fala do outro, entre a instância subjetiva que fala e a instância subjetiva que escuta de um lugar outro.

Na perspectiva da evolução do desenvolvimento, Waxmann (2006, p. 129) salienta que a aprendizagem de palavras se localiza no centro da confluência entre a cognição humana e a linguagem e que, desde cedo, os bebês formam conceitos de modo a apreender várias relações entre objetos e eventos com que se deparam, e adquirem palavras para expressá-los. As pesquisas da autora apresentam como resultados três importantes aspectos:

i) a criança inicia a tarefa de aprendizagem de palavras munida de uma expectativa ampla, inicial e universalmente disponível de que palavras novas vinculam-se a uma vasta gama de propriedades comuns aos objetos nomeados;

ii) as expectativas iniciais preparam caminhos para uma expectativa mais refinada, ajustada de acordo com as correlações entre as formas gramaticais representadas na língua materna em aquisição e os significados associados às mesmas;

iii) essas expectativas dão suporte à rápida aquisição dos cada vez mais complexos sistemas lingüístico e conceitual, os quais consistem na principal característica do desenvolvimento humano. 
Dessa forma, as pesquisas gerativistas apontam para a estreita relação entre aquisição de palavras e conceitos, em que "a descoberta dos significados associados a outras formas gramaticais deve estar ancorada na prévia aquisição de nomes e na descoberta da estrutura argumental". (WAXMAN, op. cit., p. 165)

O processo de aquisição de linguagem ou de língua materna é, portanto, de complexidade imensa e estudá-lo significa envolver vários aspectos da natureza humana. É da confluência de vários elementos (fonéticos, lexicais, sintáticos, semânticos, psicológicos, sociais, neurais, pragmáticos) que se constitui a exclusiva capacidade do ser humano de exercer a sua habilidade discursiva (cognitiva e comunicativa) e, conseqüentemente, somente a partir da confluência de várias áreas do conhecimento é que conseguiremos diminuir as lacunas da nossa compreensão sobre o processo de aquisição; mas, com certeza, muito ainda precisaremos descobrir. 
CAPITULO III 


\section{AQUISIÇÃO OU APRENDIZAGEM \\ DE LÍNGUA ESTRANGEIRA}

\section{Língua Estrangeira e Segunda Língua: em torno ao conceito}

Os estudos sobre linguagem têm incentivado, nos últimos cinqüenta anos, uma gama de estudiosos a pesquisarem também sobre a aquisição de língua materna e de língua estrangeira. Como conseqüência do interesse pelo tema, hoje dispomos de uma diversidade de termos e conceitos utilizados pelos pesquisadores - que nem sempre coincidem entre si - e, por vezes, as distintas nomenclaturas acabam causando confusão ou discussões no meio acadêmico.

Uma situação como essa existe em torno aos termos segunda língua (L2) e língua estrangeira (LE) e se correlacionam diretamente ao significado aplicado ao termo língua materna.

Vale ressaltar que língua materna não é necessariamente a língua falada pela mãe, mas aquela que foi primeiramente assimilada pelo inconsciente (MELMAN, 1992, p. 45) e que nem sempre coincide com a língua nacional de um país, pois como salienta Calligaris (1992, p. 16), o que nos faz "sujeitos" é a estrutura simbólica tomada numa rede maior, cultural e que é privilegiadamente a rede que uma história nacional organiza.

Serrani-Infante (1997, p. 68) acrescenta que devemos considerar como língua não a língua enquanto código lingüístico, mas enquanto “...estrutura verbal simbólica, cujas marcas formais ganham sentido ao se realizarem em processos discursivos historicamente determinados, e determinantes na constituição do sujeito". Dentro de processos migratórios na história de um país, por exemplo, a língua materna não será a língua nacional, mas sim a língua de origem do imigrante, prevalecendo, geralmente, segundo Gumperz (1982), até a sua terceira geração naquele país. 
Com relação à língua não materna, os termos L2 e LE têm sido muito utilizados em perspectivas diferentes e vários são os pontos de vista que levam a distintas designações para o fato de se falar ou aprender uma outra língua que não seja a sua nativa ou a preponderante em seu ambiente familiar.

Alguns pesquisadores na área da lingüística fazem diferenciação entre as duas formas. Para alguns teóricos L2 é aquela que se fala em casa, em um contexto natural, em que os membros de uma família são falantes de mais de um idioma e, em geral, considerados falantes bilíngües. Portanto, quando a criança, ao adquirir a língua materna também adquire uma segunda língua, em seu próprio lar, considera-se que seja falante de uma segunda língua.

Dabène (1994, p. 29) afirma que a língua considerada estrangeira dentro de um país é, em princípio, a língua oficial de um ou de vários Estados estrangeiros. Nesse caso, ela é falada por alguns imigrantes que fixaram residência no território ou ensinada nas escolas.

O ensino de uma língua estrangeira implica, via de regra, interesses políticos, econômicos e culturais de uma Nação.

Há casos em que a LE pode ser também falada por um número representativo de falantes em um país e, ao longo da história, acaba mesclando-se com a própria língua nacional. Surgem os dialetos e, em algumas situações específicas, uma terceira língua: o crioulo. Podemos encontrar vários exemplos na África em que as colonizações portuguesa, espanhola e francesa geraram diversos dialetos e línguas crioulo.

Segundo Richards (1985, p. 2) L2 é a língua que não é a nativa em muitos países, mas que por circunstâncias históricas, políticas e sociais faz parte da comunidade - seria o exemplo do inglês, na Índia; corrobora Baralo (1999, p. 22) que se refere à língua não nativa adquirida enquanto se é criança ou jovem. Não 
obstante, para Kuhl (2000) que também denomina segunda língua aquela que não é a nativa, admite ser aquela tanto aprendida concomitantemente à materna, como a língua aprendida tardiamente, ou seja, após os seis anos de idade.

Já o termo língua estrangeira (LE) seria a língua aprendida de maneira formal, nos bancos escolares e não implica em contato.

Por outro lado, mesmo dentro dos casos mais claros, em que a qualificação de estrangeira parece corresponder indiscutivelmente à realidade tanto dos componentes institucionais como didáticos, constata-se que uma língua pode ser mais ou menos estrangeira, ou, como afirmou Weinrich (1953): "existem graus de estrangeirismo". Esses "graus de estrangeirismo" variam de acordo com a distância material de fronteira (aspectos geográficos), a distância cultural (diferenças no nível das práticas culturais e dos sistemas de valor em vigor dentro da sociedade ou de tradições educativas) e a distância lingüística. A noção de língua estrangeira, portanto, refere-se a situações muito diversas: é possível considerar que elas se constituem num continuum ativo de estrangeirismo - desde o aspecto de vizinhança até a familiaridade, aqui podendo aplicar-se às coletividades (dimensões geográficas ou individuais).

Nesta tese, empregaremos o termo língua estrangeira quando nos referirmos ao ensino de espanhol no Brasil, considerando que, na cidade de São Paulo, não é uma língua de contato e nem de fronteira, mas sim, uma língua que é ensinada nas escolas, por uma gama diferenciada de interesses - políticos, econômicos e culturais.

\section{Aquisição ou Aprendizagem: outra controvérsia conceitual}

Os estudos sobre a linguagem sempre trazem à tona uma velha discussão entre os teóricos: o que é aquisição e o que é aprendizagem e em que medida 
elas se relacionam no desenvolvimento lingüístico do ser humano. Conforme apontou Carioni (1988, p. 50): "Nenhum desses campos foi explorado o suficiente para se ter respostas certas sobre como se processa a aquisição, seja de língua materna ou segunda língua."

Em geral, os termos aquisição e aprendizagem são empregados em situações diferentes de ensino de língua. Enquanto o primeiro termo é usado para o ensino de língua materna, o segundo refere-se ao ensino de língua estrangeira, preferentemente.

Krashen (1981) estabeleceu outra linha de demarcação, ampliando o significado de aquisição à aprendizagem de uma L2 que se realiza de forma similar àquela como a criança aprende a sua língua materna: por simples contato direto. Desta forma, o termo aprendizagem normalmente implica o estudo formal de L2, geralmente em sala de aula, com professor, explicações gramaticais, exercícios de conhecimento explícito da língua, simulação de situações para fomentar o diálogo em L2 etc. (MARTíN-MARTíN, 2004)

Em seus estudos sobre aquisição/aprendizagem de segundas línguas, Krashen $^{9}$ (1977) baseia-se na premissa de que "aquisição e aprendizagem são dois fenômenos diferentes, de origens diferentes, com finalidades diferentes, podendo ocorrer simultaneamente, sem que o último seja causa do primeiro". A partir dessa premissa, levantou a hipótese de que aquisição é um processo que ocorre no nível do subconsciente, funcionando por força da necessidade de comunicação enquanto impulso vital e natural, sem que o falante tenha consciência das formas lingüísticas, uma função que o cérebro não pode evitar de cumprir ao ser exposto aos impulsos auditivos identificados como mensagem codificada em língua. Aprendizagem significa saber as regras, ter consciência delas, poder falar sobre elas, exigindo, portanto, um esforço consciente e

\footnotetext{
${ }^{9}$ Para este trabalho, foi utilizada a versão traduzida do original de KRASHEN, S. The monitor model for adult second language performance, em BURT, M.; DULAY, H..; FINOCCHIARO, M. (Ed.) Viewpoint of English as a second language. New York: Regents, 1977, p. 152-161, publicada em LICERAS, J. M. La adquisición de las lenguas extranjeras. Trad. Marcelino Marcos. Madrid: Visor, 1991.
} 
conseqüente de uma situação formal de aprendizagem ou de um programa de estudo individual. Em outras palavras, uma significa saber "usar" a língua, a outra saber "sobre" a língua."

Para Krashen (1977, p. 145), os que estão adquirindo uma língua não têm consciência das regras gramaticais da linguagem e não têm preocupação com elas, ao passo que os que estão aprendendo uma língua têm consciência das regras, se preocupam com elas e são capazes de falar sobre elas. Por isso, é possível estabelecer que a aprendizagem de uma língua pode ser algo comparado a aprender sobre uma língua. Ressalta, ainda, que a aquisição ocorre de forma subconsciente e é característica da internalização "natural" da linguagem típica das crianças, quer seja para o caso de língua materna como para o caso de outras línguas. Trata-se de uma construção criativa e informal que consiste na aplicação de estratégias universais que conduzem à aquisição do sistema adulto ou nativo, dependendo do caso. Por sua vez, a aprendizagem é um processo consciente e característico da internalização "formal" da linguagem, que implica a retroalimentação, a correção de erros e a explicitação de regras.

Embora a aquisição seja típica das crianças e a aprendizagem dos adultos, isso nem sempre é tão marcado assim, de forma que poderemos, muitas vezes, encontrar também processos de construção criativa ou aquisição de linguagem em adultos (Krashen, op. cit., p. 145). O modelo do monitor de Krashen é uma das teorias existentes sobre o ensino-aprendizagem de segundas línguas e se baseia nos trabalhos de Labov que, em 1970, usou esse termo pela primeira vez em seu estudo sobre aquisição de primeira língua. Krashen salienta que a instrução formal não tem efeitos sobre a aquisição; serve apenas para monitorar ou editar a produção do aprendiz dentro das seguintes condições: deve haver tempo suficiente; o foco da interação deve estar na forma e não no significado; e o aprendiz deve conhecer a regra em questão. Em outras palavras, a aprendizagem funciona como monitor da produção do aprendiz sem, contudo, causar-Ihe algum efeito. 
De acordo com as pesquisas de Labov (1970, p. 35), no uso da primeira língua, sob condições em que a utilização do monitor é difícil, surgem na fala os dialetos adquiridos durante as primeiras etapas do desenvolvimento. Isso sugere, ainda, que a manutenção das formas de prestígio, que se aprendem tardiamente, se dá por meio do uso de um áudio-monitor consciente. Essas formas podem se desvanecer quando as condições dificultam o uso do monitor (por exemplo, quando o falante está cansado, distraído ou é incapaz de se ouvir). Krashen (1977, p. 146) sugere que um processo similar pode ser aplicado à atuação dos adultos e que os erros que surgem de situações em que o uso do monitor é possível serão mais idiossincráticos, e refletirão a representação mental consciente que cada falante tem das regularidades lingüísticas da língua objeto.

Ainda que os estudos realizados por Krashen, a partir do modelo do monitor, tenham apresentado resultados variáveis quanto à sua eficiência, um dado pelo menos pode ser levantado: a intrínseca relação entre aptidão e atitude diante desse modelo. O autor averiguou que a aptidão parece estar relacionada diretamente com a competência do monitor e seus efeitos aparecem quando os testes implicados facilitam seu uso. Nesse caso, os resultados obtidos em testes de aptidão refletem, geralmente, a atuação do falante. Por outro lado, as medidas de atitude - como motivação para integrar-se, capacidade empática e as atitudes favoráveis em direção a uma situação de aprendizagem - parecem estar relacionadas diretamente com a aquisição. Quando não há presença de monitor, a suficiência em língua estrangeira apresenta maior participação da atitude do falante (obtida a partir da aquisição) e menor da sua aptidão (obtida a partir da aprendizagem) (op. cit., p. 147).

Nesse sentido, abordando ou não a teoria do monitor, encontramos no processo de aquisição e aprendizagem de línguas estrangeiras fases em que dois sistemas lingüísticos parecem misturar-se, quer por insipiência quer por falta de monitoração. Surgem os dialetos, citados por Labov, nas primeiras etapas do processo. Esses dialetos são também chamados "dialetos idiossincráticos" por Corder (1991, p. 66) e de "interlíngua" por Selinker (1972, p. 83). 
Em seu trabalho sobre a distinção entre aquisição e aprendizagem de línguas, Krashen (1977) alega que adultos não perdem a habilidade de adquirir línguas. Segundo esse autor, a única diferença é a de que a correção do erro tem um efeito pequeno na aprendizagem da primeira língua da criança e, neste caso, corrigir demais afeta pouco na aquisição da linguagem. No caso do adulto, ao contrário, parece influenciar positivamente para alguns falantes.

Yule (1985, p. 191) considera que o termo aquisição, quando usado na linguagem, se refere ao desenvolvimento gradual de habilidade em uma língua quando ela está sendo usada em situações naturais de comunicação. Entretanto, o termo aprendizagem refere-se a um processo consciente de acúmulo de conhecimento do vocabulário e da gramática da língua. Isso significa que Yule considera a distinção a partir de uma experiência em situações naturais - seja por ser a língua materna ou por ser uma segunda língua adquirida em situação natural.

As comunidades bilíngües, em que a criança se insere em longos períodos de interação social, seriam um bom exemplo de "situação natural", em contraposição às atividades desenvolvidas em processos formais de ensino, como a escola, onde a criança aprende "sobre" a língua.

Os trabalhos de Yule mostram que aqueles cuja segunda língua foi aprendida tendem a não desenvolver a mesma proficiência daquela que foi adquirida e, por outro lado, mesmo em situações ideais de aquisição, poucos são os adultos que conseguem chegar a um grau de "nativo" da segunda língua. Há também uma distinção na aquisição: alguns conseguem ficar proficientes na escrita, mas não na produção oral, o que sugere que alguns elementos são mais facilmente adquiridos que outros, como por exemplo, vocabulário e gramática, e alguns mais difíceis, como a fonologia. Os estudos realizados por Yule levam-no a afirmar que, após a puberdade, é difícil conseguir a aquisição plena de uma segunda língua e que sua aquisição depende de uma combinação de fatores. A melhor idade para isso seria entre os dez e os dezesseis anos, época em que a 
"flexibilidade" da faculdade de aquisição de línguas não estaria totalmente perdida e a maturidade das habilidades cognitivas permitiria um êxito efetivo no uso das características da segunda língua (op. cit., p. 191).

Entretanto, até agora, não há estudos que comprovem a relação de desempenho lingüístico e idade em que se adquire/aprende uma língua estrangeira. Tudo indica que há um fator individual que envolve estratégias, aptidões e atitudes para que um falante, independentemente de sua idade, tenha um resultado que se aproxime da fala de um nativo. Estudos de Selinker (1972) e de Krashen (1977) mencionam, por um lado, vários exemplos de adultos que aprenderam outra língua tardiamente e que apresentam uma produção oral espontânea similar à nativa, sobretudo em contextos em que podem utilizar o monitor - como durante uma conversação lenta ou quando escrevem - e, por outro lado, mostram outros casos em que parece que o falante nunca o utiliza ou raramente faz uso do conhecimento lingüístico consciente em sua atuação (KRASHEN, op. cit., p. 149).

O modelo do monitor ainda é bastante discutível, mas há autores, como Scarpa (1999), que concordam com o fato de que não somente as crianças são capazes de "adquirir" uma língua, mas os adultos também.

Kuhl (2000) utiliza o termo aprendizagem para referir-se a estratégias que levarão crianças e adultos à aquisição, considerando, portanto, que adquirir uma língua (seja materna ou não) é o resultado de um processo de aprendizagem. Isto decorre do fato de basear-se em testes laboratoriais a partir de uma observação profunda das reações cerebrais. Situam-se, aqui, os experimentos em que os informantes são conectados a sensores e submetidos a estímulos eletromagnéticos. Esse tipo de experiência constitui um dos trabalhos mais recentes na área da neurolingüística e, nesse caso, a distinção entre aquisição e aprendizagem não se faz presente. 
Esta pesquisa trata a questão com imparcialidade, e considera o termo aquisição/aprendizagem de línguas. Tal escolha se fundamenta no fato de ser uma pesquisa voltada para a questão da produção de aprendizes brasileiros de língua estrangeira e não no mérito de se tentar estabelecer uma distinção para esses conceitos. Por outro lado, torna-se complexo analisar até que ponto o desempenho de um aprendiz, nos moldes conseguidos para este trabalho, está submetido somente à "aprendizagem", no sentido formal, e não ao contato permanente com falantes nativos da $\mathrm{L} 2$ e, mesmo que os dados tivessem sido levantados, seria quase impossível - em uma pesquisa transversal como esta se caracteriza - avaliar em que medida o desempenho seria conseqüência de um ou de outro fator.

\section{As estratégias de aprendizagem}

A aquisição/aprendizagem de uma língua estrangeira implica uma série de questionamentos que ainda estão sendo estudados pelos pesquisadores. As questões mais destacadas coincidem com a necessidade de entendimento dos mecanismos e processos de aquisição/aprendizagem da linguagem, ainda que com algumas variantes distintas, sobretudo quando o indivíduo já é falante de sua língua materna.

Um elemento importante a considerar nesse caso são as estratégias utilizadas pelos indivíduos durante o processo de aquisição/aprendizagem tanto de língua materna, como de língua estrangeira. Segundo Fernández-López (2004, p. 411) compreende-se por estratégias as "operações mentais, mecanismos, técnicas, procedimentos, planos, ações concretas que se utilizam de forma potencialmente consciente e que mobilizam os recursos para maximizar a eficácia tanto na aprendizagem como na comunicação". ${ }^{10}$

\footnotetext{
${ }^{10}$ Tradução nossa
} 
Sabe-se que as estratégias adotadas assumem um caráter individual, embora alguns procedimentos parecem ser comuns a todos os aprendizes. Pesquisas mostraram que é difícil aprender o significado das palavras em língua materna somente pelo contexto; de alguma forma, parece que o melhor desempenho se dá quando inseridas em uma estrutura sintática (GLEITMAN, 1990; GILLETTE et alii.,1999). A exploração de recursos prosódicos e não lingüísticos também parece ser um fator preponderante no processo. Algumas técnicas que exploram o uso da prosódia, do olhar e do gesto estão sendo utilizadas de modo a descobrir aquilo que a criança é capaz de perceber acerca da língua quando ainda não se expressa de forma lingüística (NAME; CORRÊA, 2006).

Em língua materna, Corrêa (2006, p. 21) comenta que os estudos mais recentes apresentam resultados que indicam que o modo de operação das línguas humanas atende a restrições impostas pelos sistemas de desempenho e, desta forma, uma teoria da aquisição de linguagem tem de ser fundada em um diálogo interdisciplinar, que envolva a psicolingüística e os estudos de cognição para que se possa entender o modo como se processa a interface entre a fonética e as informações de ordem conceptual que possam induzir a fixação de parâmetros fundamentais nos dois primeiros anos de vida da criança. Parece haver uma íntima relação entre as informações de ordem fonética e as de ordem sintáticosemântica para a lexicalização da língua (CORRÊA, op. cit., p. 65-66).

Ainda não há nada comprovado no tocante à aquisição/aprendizagem de língua estrangeira que aponte para o mesmo caminho. Ao longo dos últimos sessenta anos, várias metodologias de ensino de línguas estrangeiras tentaram explorar alguns desses procedimentos mais que outros. Assim, a história dessas pesquisas nos brindou com metodologias que nasceram explorando o ensino do léxico e de estruturas e regras gramaticais, como é o caso do Método Tradicional de ensino, utilizado durante a primeira metade do século passado. Nos anos 50 , com o desenvolvimento de recursos tecnológicos, como gravadores e televisão, surge o Método Áudio-lingual, em que se começou a explorar a necessidade de se aprender a oralidade; posteriormente, o Enfoque Comunicativo ganha força 
entre os professores de ensino de línguas que compreendiam a importância de se adquirir/aprender línguas estrangeiras em suas quatro habilidades - compreensão e produção oral e escrita - mediante textos autênticos e de imersão na L2. Finalmente, nos anos 90, desenvolve-se uma nova metodologia conhecida como Enfoque por Tarefa, em que 0 contexto situacional de determinadas manifestações da língua é valorizado.

Paralelamente, nas últimas décadas, algumas metodologias alternativas tendem a explorar mais enfaticamente os recursos prosódicos e os aspectos físicos e biológicos dos seres humanos, valorizando procedimentos que reforcem os sentidos auditivos e visuais, bem como aspectos biológicos do homem, com o intuito de garantir um melhor desempenho na aquisição/aprendizagem. Nessa linha, estão os trabalhos de perspectiva holística e antroposófica - neste último caso, desenvolvidos pela metodologia Waldorf - que exploram estratégias dessa natureza, valorizando a essência do ser humano e buscando a harmonia entre inteligência, sentimentos e ações. A visão holística considera que há diferenças individuais que fazem com que cada um dos seres humanos tenha maior facilidade através de um determinado sentido em detrimento de outros no momento da aquisição/aprendizagem de línguas e a antroposófica defende o conhecimento humano como o resultado das experiências vividas no seu hábitat e privilegia todos os elementos do sistema orgânico para a realização das ações. Para a antroposofia, o ensino/aprendizagem está diretamente ligado ao próprio sistema em que o corpo humano e o universo se organizam, numa perspectiva da individuação, em que se valorizam as polaridades e o espiritualismo humano.

Falar de aquisição/aprendizagem de línguas estrangeiras implica ressaltar a questão do ensino e as trilhas que se têm traçado nesse campo. Quando esse processo ocorre em um contexto natural - aquele em que o aprendiz está em contato permanente com a L2 e, em geral, em uma situação familiar de bilingüismo, a aprendizagem se faz mediante estratégias que se aproximam das adotadas pela criança na aquisição da língua materna. Entretanto, no caso da aprendizagem formal, em sala de aula, tanto professor como aluno utilizam estratégias que podem se diferenciar daquelas do contexto de aquisição pelo 
bebê. Neste processo, estão em jogo alguns fatores individuais do aluno como os cognitivos, psicológicos, sociais (idade e sexo) e comportamentais (atitude do aprendiz), que influenciam o desenvolvimento da aprendizagem, bem como recursos e estratégias utilizados pelos professores com relação ao grupo ao qual ensina. O êxito da instrução formal, entretanto, é variável e poder-se-á encontrar diferentes resultados no desempenho da L2 em uma mesma situação de ensino.

De todas as formas, o input (contato visual e auditivo) é essencial no processo de aprendizagem de uma língua estrangeira e deve estar adaptado e aumentar progressivamente. Martín-Martín (2004, p. 271) salienta que "para que o input seja produtivo deve ser compreensível e compreendido (intake)" e que o falante adapta o seu discurso para transformá-lo em um discurso compreensível mediante a simplificação da mensagem, a seleção do léxico ou a articulação clara e lenta dos sons. Desta forma, facilita a comunicação momentânea entre ele e o seu interlocutor e contribui - possivelmente de forma inconsciente - para a sua aprendizagem da L2 (MARTíN-MARTíN, op. cit., p. 272).

Atualmente, com o avanço das pesquisas na área do interacionismo sociodiscursivo, considera-se, também, a relevância no uso das estratégias que desenvolvam as relações sociais para a promoção da interação.

Complementarmente, os estudos sobre "identidade e identificação", na área da análise do discurso, uma visão pscicanalítica da construção discursiva e da produção oral na LE, abordam a necessidade de se considerar a afetividade relacionada à aprendizagem. Serrani-infante (1997, p. 79) ressalta que as estratégias dos aprendizes estão "ligadas ao desafio de lidar com o estranhamento e as novas possibilidades de significância" e que, na verdade, "representam, no nível do imaginário do intradiscurso, o jogo de identificações simbólicas determinantes do sujeito". Por isso, no contexto de sala de aula, no caso específico de aprendizes concretos, a autora considera que, devido à impossibilidade de estabelecer paralelismos simplificadores ou determinações lineares sobre alguma forma dada de aprendizagem da língua estrangeira e algum 
tipo específico de relação com a língua materna, a única alternativa do professor é mobilizar o seu aluno a "procurar decifrar sentidos postos em jogo pela(s) sua(s) relação(ões) com as línguas que o habitam". Isso significa, na concepção da pesquisadora, que a importância histórica do sujeito da enunciação, a relação com a língua materna (L1) e a interdiscursividade fundadora são elementos importantes a serem considerados para o desenvolvimento de estratégias de ensino.

\section{Competências necessárias para o aprendiz de língua estrangeira}

Os estudos neurolingüísticos mais recentes sugerem que o aprendizado depende muito mais da experiência lingüística do que do tempo. Crianças de até seis meses expostas a dois idiomas que convivam em seu meio-ambiente - pai usando um e a mãe outro - terão dois locais diferentes de categorias fonéticas mapeados em seu cérebro, conforme os trabalhos apresentados por Kuhl (2000) e são capazes de aprender de forma muito mais eficiente do que aquelas cujos pais falam os dois idiomas indiscriminadamente. Outros testes realizados permitiram ver que adultos bilíngües que adquirem ambas as línguas muito cedo, ativam regiões sobrepostas do cérebro quando do processamento das duas línguas, enquanto aqueles que aprendem a segunda língua tardiamente ativam duas regiões distintas do cérebro para as duas línguas. Assim, é bastante consistente a idéia de que o processamento da primeira língua pode interferir no da segunda.

Portanto, parece que quando se estuda o aprendizado tardio de uma outra língua, a região mapeada no cérebro se altera quando este é exposto a estímulos eletromagnéticos. Os novos estudos com treinamento sugerem que exagerar nas dimensões de comparação da língua estrangeira, bem como prover o ouvinte com muitos exemplos de fala e expô-los a muitos falantes, são formas eficientes de treinamento. 
Os experimentos realizados por Kuhl demonstraram que não é necessário que haja um feedback ou reforço, os ouvintes necessitam simplesmente de uma experiência correta de audição. Exemplo disso é o motherese, como já o mencionamos anteriormente, em que os sinais acústicos exagerados, os vários exemplos dados por diversos falantes e a experiência de audição em massa representam um papel fundamental no desenvolvimento lingüístico dos bebês. Isso permite afirmar que se houver uma reunião neural diferente na estrutura de aprendizagem, ela poderá interferir no processo de informação que não estará em conformidade com o aprendizado padrão (da primeira língua), dificultando o aprendizado tardio de uma segunda língua e, nesse sentido, o aprendizado inicial poderá alterar o aprendizado futuro. O período crítico para a linguagem é influenciado não somente pelo tempo mas pela rede neural que resulta da experiência.

A autora ainda observa que esses princípios sugerem que não existe uma gramática ou fonética universais, mas sim desvios ou estratégias inatas que dão lugar a controles de percepção e aprendizagem e que permitem que as crianças recuperem do input da linguagem regras pelas quais as pessoas de sua comunidade se comunicam e, ainda acrescenta, que tais estratégias de aprendizagem utilizadas podem ter, elas mesmas, influenciado a natureza da linguagem, do mesmo modo como os processos gerais de audição influenciaram a seleção de unidades fonéticas para a linguagem durante sua evolução (KUHL, 2000).

Ao conjunto organizado de conhecimentos formado por vários componentes, tais como o fonológico, morfológico, sintático, semântico e léxico (TRUJILLO-SÁEZ, 2001, p. 4), denominamos competência lingüística.

O termo competência lingüística foi usado por Coseriu em 1952, em sua obra Sistema, Norma e fala e retomado, pelo autor, em trabalhos posteriores. Para Coseriu, a competência lingüística corresponde ao saber lingüístico e, na fala, engloba três classes distintas de saber: o saber elocutivo, o saber idiomático e o 
saber expressivo (COSERIU, 1983, p. 287) que se interferem ou podem interferirse. O primeiro se refere ao conhecimento das coisas, saber algo que vai além do saber idiomático. Este, por sua vez, trata da própria estrutura e conteúdo da língua e da relação de determinante e determinado que nela se insere. Finalmente o saber expressivo é aquele que determina a aplicação e interpretação do saber idiomático e depende, por exemplo, da temática do discurso (COSERIU, op. cit., p. 288). Os saberes elocutivo e expressivo se estruturam, segundo o autor, em sentido amplo e possuem normas que são na maior parte das vezes comportamentais e não regras fixas, podem ser, portanto, muito diferentes e heterogêneas.

Chomsky (1959) propôs uma diferença entre competência e atuação (em inglês, performance). Considerando a relação falante/ouvinte, definiu competência como sendo o conhecimento que o falante/ouvinte tem da língua, e performance o uso real da língua em situações concretas. Entretanto, o conceito de competência, ao qual se dedicou exclusivamente, baseia-se no estudo da língua como sistema e não desde uma perspectiva de uso.

Posteriormente, os estudos etnográficos de Hymes (1972), contrários aos conceitos chomskyanos, apontaram a necessidade de se relacionar os elementos estruturais (morfológicos, fonológicos etc) aos aspectos culturais, sociais e de linguagem, sobretudo para o ensino de línguas estrangeiras. Surge então, o conceito de competência comunicativa que se define como:

(...) o conhecimento que nos permite utilizar a linguagem como instrumento de comunicação em um contexto social determinado; é um conceito dinâmico baseado na negociação de significado entre os interlocutores, aplicável tanto à comunicação oral como à escrita, que se atualiza em um contexto ou uma situação particular. (TRUJILLO-SÁEZ, 2001, p. 4)

Assim, a perspectiva abordada diz respeito a uma competência que associa o conhecimento de regras gramaticais ao uso da língua, diferentemente da 
proposta chomskyana, e se aplica de forma mais satisfatória à aquisição e ensino de línguas (CENOZ-IRAGUI, 2004, p. 450).

Alguns anos mais tarde, Chomsky (1980, p. 224) admitiu a existência de uma competência pragmática, referente ao conhecimento das condições e modo de uso apropriado a diferentes fins, e uma competência gramatical associada ao conhecimento da forma.

Embora os conceitos propostos por Chomsky e Hymes sejam diferentes, os de Chomsky estimularam outros pesquisadores a desenvolver estudos sobre a competência e, conseqüentemente, surge uma gama muito grande de trabalhos na área científica que abordam questões e conceitos relacionados às competências lingüísticas e comunicativas, bem como de subcompetências que se dividem em distintas categorias: gramatical, léxico-semántica, sociocultural, pragmática, estratégica.

Para Cenoz-Iragui (2004, p. 452) há pelo menos três importantes modelos de competência comunicativa:

1. O modelo de Canale y Swain, de 1980, que considera três componentes (sub-competências) da competência comunicativa, a saber:

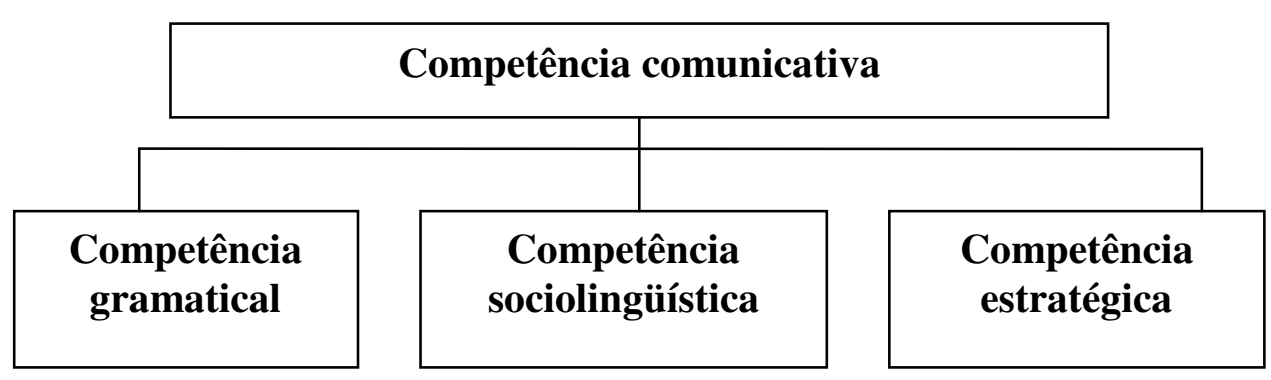


A competência gramatical envolve os conhecimentos dos elementos léxicos e as regras de morfologia, sintaxe, semântica - a nível de gramática da oração - e fonologia que permitem a compreensão e expressão exatas no idioma estrangeiro.

A competência sociolingüística permite usar a língua segundo as normas de uso e as normas do discurso que servem para interpretar os enunciados em seu significado social. Refere-se, portanto, a determinar que enunciados são apropriados a determinadas situações e contextos sociais em que pesem o status dos participantes, o propósito da interação e as normas ou convenções da interação. Em 1983, Canale (Cf. CENOZ-IRAGUI, 2004) reelaborou o seu modelo e diferenciou a competência sociolingüística da competência discursiva, que se refere ao modo como se combinam as formas gramaticais e significados para se obter um texto falado ou escrito unificado. A unidade do texto se consegue por meio da coesão na forma e da coerência no significado.

A competência estratégica está formada pelas estratégias de comunicação verbal e não verbal utilizada tanto pelos falantes nativos como pelos estudantes de línguas para compensar as suas limitações de conhecimento lingüístico que podem surgir no momento da produção oral e interferir no ato da comunicação.

2. O modelo de Bachman, de 1990, tenta estabelecer a dimensão da competência comunicativa. Este modelo provém da área da avaliação de línguas dentro da aquisição de L2. 


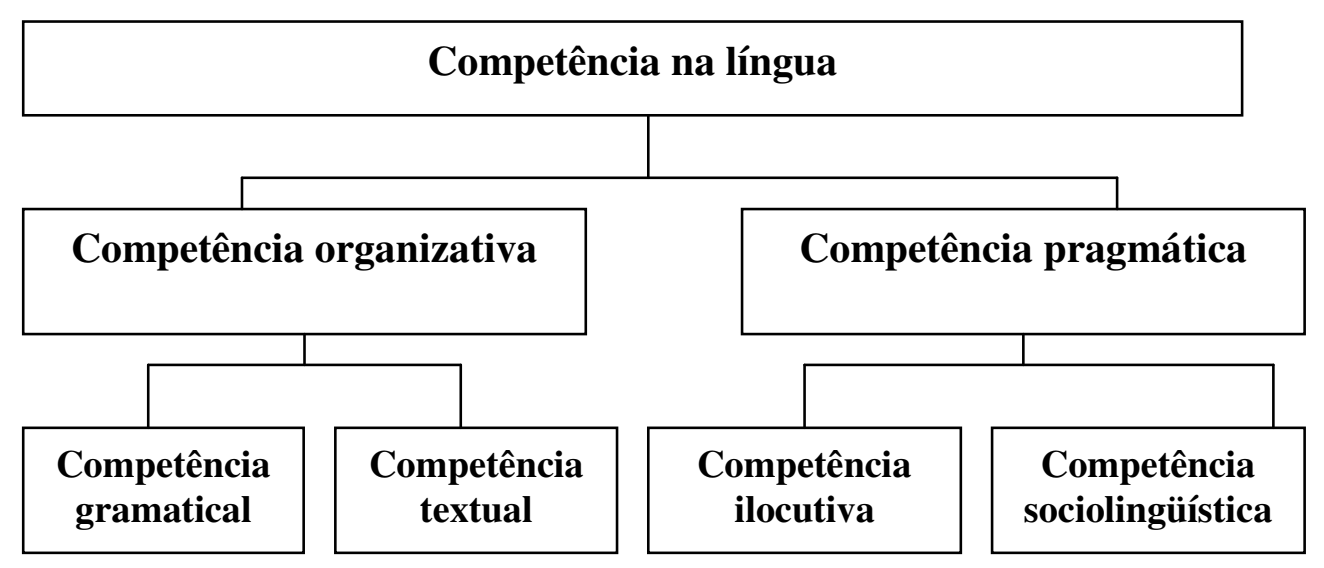

A competência organizativa inclui as habilidades relacionadas à estrutura formal da língua: a competência gramatical, que abarca a competência de uso lingüístico (semelhante à de Canale e Swain); e a competência textual, que trata do conhecimento das convenções para unir enunciados de modo a formarem um texto (semelhante à competência discursiva de Canale). Nessa proposta, a competência textual está ligada aos elementos de coesão textual (marcas que explicitam as relações semânticas, tais como referência, elisão, ou coesão léxica; e a organização retórica, que se relaciona com o efeito do texto no usuário da língua (consideram-se, assim, os métodos comuns de desenvolvimento, como a narração, descrições, comparações, classificações e análise do processo).

A competência pragmática refere-se às relações entre signo e referentes e também às relações entre usuários da língua e contexto de comunicação. Incluem as competências ilocutiva - concernente à relação entre os enunciados e os atos ou funções que os falantes tentam realizar por meio dos enunciados - e sociolingüística - associada à caracterização das condições que estabelecem quais enunciados são apropriados em determinadas situações e determinam 0 registro, variedade dialetal e referencias culturais (similar ao conceito de competência sociolingüística de Canale y Swain).

Segundo Cenoz-Iragui (2004), da mesma forma que Canale e Swain revisaram os seus modelos, Bachman também o fez, em conjunto com Palmer, 
em 1996. A competência pragmática, para os autores, passa a ser composta por: léxico (que antes estava na gramatical), conhecimento funcional - que se refere às relações entre os enunciados $e$ as intenções comunicativas dos falantes (semelhante à ilocutiva) e conhecimento sociolingüístico. Também passam a considerar a competência estratégica como estratégia metacognitiva.

3. O modelo de Celce-Murcia, Dörnyei y Thurrell, de 1995.

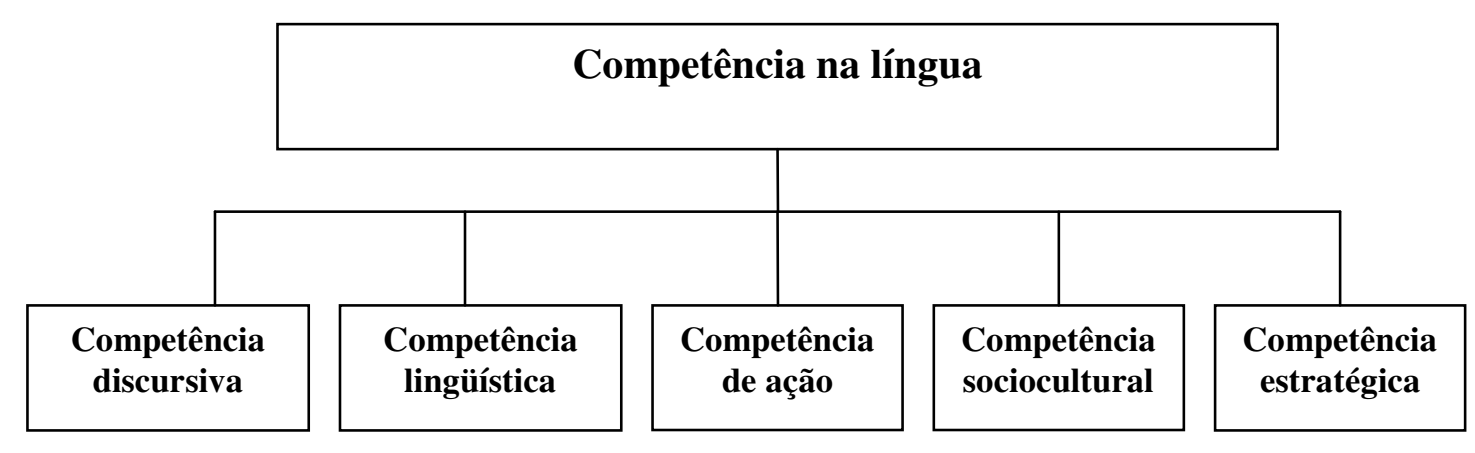

Segundo Cenoz-Iragui (2004, p. 458), no modelo de Celce-Murcia, Dörnyei y Thurrell, há grande interesse pelo peso relativo dos componentes, pela posição central da competência discursiva e por estar centrado na interação entre os componentes, além de oferecer uma descrição detalhada da competência comunicativa.

Nesse modelo, a competência discursiva se refere à seleção, seqüência e organização de palavras, estruturas, frases e enunciados para se obter um texto oral ou escrito unificado. A coesão, dêixis, coerência, estrutura genérica e estrutura convencional concernente à alternância de turnos são os seus componentes básicos. 
A competência lingüística corresponde, genericamente, ao conceito de competência gramatical de Canale e Swain (1980) - isso porque quis enfatizar o componente fonético além do gramatical.

A competência de ação (ou pragmática e ilocutiva) é a habilidade para transmitir e entender a intenção comunicativa ao se realizar e interpretar os atos de fala e funções lingüísticas.

A competência sociocultural se refere ao conhecimento que o falante tem para expressar mensagens de forma apropriada no contexto sociocultural da comunicação. Inclui as variáveis individuais, situacionais etc.; os fatores estilísticos (convenções de cortesia, graus de formalidade etc.); fatores culturais (conhecimento da forma de vida na comunidade, conhecimento de diferentes regiões etc.) e os fatores de comunicação não-verbal (gestos, uso do espaço etc.). Assemelha-se à competência sociolingüística, mas no presente modelo se apresenta de forma mais completa.

Por fim, a competência estratégica se refere ao uso das estratégias de comunicação - consideradas tanto a partir de uma perspectiva psicolingüística como, especialmente, de interação.

Nesse modelo, a competência discursiva tem um papel central e se relaciona com as competências lingüística, de ação e sociocultural; ao lado está a competência estratégica com a qual - mediante uma série de estratégias utilizadas - os falantes conseguem resolver ou compensar deficiências nas outras competências (CENOZ-IRAGUI, 2004, p. 458).

Cook, em 1992 (Cf. CENOZ-IRAGUI, 2004, p. 460) criou o termo multicompetência para referir-se às competências necessárias por falantes que não somente adquirem/aprendem uma segunda língua, senão mais de uma, sendo, portanto, considerados falantes plurilíngües. Segundo Cook, a maneira 
como a aquisição/aprendizagem se realiza nesse contexto é diferente do contexto de mono ou bilingüismo. Em uma situação de plurilingüismo, os falantes utilizam suas línguas em diferentes contextos e para diferentes funções e usos e, em um processo de avaliação, os critérios não podem ser os mesmos que os aplicados aos falantes monolíngües.

Sendo assim, Cenoz-Iragui (op. cit., p. 460) conclui que:

Portanto, ainda que todos os componentes que fazem parte da competência comunicativa (lingüística, pragmática, sociolingüística, discursiva e estratégica) sejam necessários para a comunicação efetiva em várias línguas, a competência plurilíngüe também apresenta algumas características especiais que a distinguem da monolíngüe. Ainda que os falantes plurilíngües necessitem todos os componentes da competência comunicativa, normalmente não precisam desenvolver todos os componentes para todas as situações comunicativas em todas as línguas. ${ }^{11}$

Em certa medida, o avanço na área dos estudos sobre aquisição e ensino de línguas contribuiu para que houvesse uma convergência para o estudo da competência conversacional, uma vez que a maioria das pesquisas hoje está voltada ao estudo da língua em seu contexto e em sua situação de produção e, especialmente, ao processo e habilidade do falante/ouvinte - em contraposição aos trabalhos iniciais de Chomsky, cuja preocupação estava em estudar a competência como estado e conhecimento (CENOZ-IRAGUI, op. cit., p. 452).

Por sua vez, a competência comunicativa difere ainda da competência conversacional que se estabelece a partir do fato de que em uma conversação os interlocutores demonstram uma habilidade que exige capacidade cognitiva para

\footnotetext{
${ }^{11}$ Tradução nossa do original "Por lo tanto, aunque todos los componentes que formam parte de la competencia comunicativa (lingüística, pragmática, sociolingüística, discursiva y estratégica) son necesarios para la comunicación efectiva en varias lenguas, la competencia pluriligüe también presenta algunas caracterísitcas especiales que la distinguen de la monolingüe. Aunque los hablantes plurilingües necesitan todos los componentes de la competencia comunicativa, normalmente no precisan desarrollar todos los componentes para todas las situaciones comunicativas en todas sus lenguas."
} 
produzir e compreender de forma imediata enunciados lingüísticos e capacidade interativa para negociar com os participantes a construção mútua do discurso (GARCÍA-GARCÍA, 2004, p. 1).

O ensino de língua estrangeira visa a proporcionar ao aluno subsídios que Ihe permitam desenvolver competências que Ihes auxiliem na comunicação no idioma alvo e que sejam capazes de comunicar informação e de se relacionarem socialmente. Isso quer dizer que é importante que adquiram confiança suficiente para manter uma conversa com falantes nativos, integrando-se plenamente à vida social e cultural dessa comunidade (GARCÍA-GARCÍA, op. cit., p. 1). 
CAPÍTULO IV 


\section{OS MARCADORES CONVERSACIONAIS: \\ UMA PERSPECTIVA TEXTUAL-INTERATIVA}

\section{A Análise da Conversação: parâmetros teóricos para esta pesquisa}

\section{A base pragmática}

Este trabalho toma como base teórica os estudos de lingüística na Área da Pragmática e da Análise da Conversação, porque entendemos que o nosso objeto de estudo somente poderá ser analisado mediante a compreensão de que a competência conversacional na aquisição/ aprendizagem de uma língua estrangeira, sobretudo quando ela é língua-irmã da materna, depende de um espaço de interação entre os falantes e de percepção da língua alvo que toma o outro como elemento norteador para as suas intervenções/respostas e, conseqüentemente, para a sua relação social e comunicativa.

Sabemos que os estudos em torno da Pragmática nasceram dentro da Filosofia, mas logo se estenderam ao campo da Lingüística, cujas teorias de uso da linguagem trouxeram à luz os sentidos das palavras na sua relação com falantes e contextos.

Pinto (2001, p. 47) salienta que "a pragmática analisa, de um lado, o uso concreto da linguagem, com vistas em seus usuários e usuárias, na prática lingüística; e de outro, estuda as condições que governam essa prática."

Entretanto, tal análise só é possível à medida que a linguagem considerando-se a fala e não somente a língua, segundo a concepção de Saussure - é estudada dentro de seu entorno social. 
É consenso que, para os estudiosos da pragmática, os fenômenos lingüísticos não são puramente convencionais, mas sim "compostos também por elementos criativos, inovadores, que se alternam e interagem durante o processo de uso da linguagem" (PINTO, 2001, p. 48).

A Grécia antiga utilizou o termo $\pi \rho \alpha \tau \chi \alpha$ para designar prática / ação - e foi o entendimento da prática como ação que deu origem aos estudos pragmáticos na área da Filosofia.

No século XVIII, Immanuel Kant, da antiga Prússia, teceu uma série de reflexões que o levaram a concluir que os estudos filosóficos deveriam ser compreendidos como um conjunto de critérios para avaliar o modo pelo qual a mente consegue construir representações. A partir da teoria kantiana, no século XIX passou-se a defender que a representação é antes lingüística que mental, e que se deve refletir primeiramente sobre a filosofia da linguagem do que sobre a crítica transcendental.

Não obstante, no final do século XIX, os estudos na área da pragmática ganharam força. Com os estudos do filósofo norte-americano Charles Sanders Peirce, de 1878, em seu artigo denominado How to make our ideas clear, publicado na revista Popular Science Monthly, se estabelece o princípio do pragmatismo, mediante o qual somente se pode dizer as coisas com clareza quando se considera quais são os efeitos concebíveis de natureza prática que o objeto pode abarcar, quais sensações podemos esperar dele e quais reações devemos preparar. É o idealizador da "tríade pragmática", que representa a relação entre signo, objeto e interpretante. Mostrou a necessidade de teorizar a linguagem levando-se em conta o signo e aquilo a que esse signo se refere e, principalmente, a quem ele significa. Foi o primeiro a trabalhar o conceito filosófico contemporâneo de "semiótica" como uma teoria geral de representação e interpretação. 
Vinte anos mais tarde, outro norte-americano, William James, recorre às idéias de Peirce e as aplica à religião, valorizando a pessoa que fala como aquela que detém o próprio significado, uma vez que a verdade, palavra-chave na compreensão da relação entre mundo e linguagem, é aquilo que nós, inseridos em uma comunidade, queremos que ela seja. Essa idéia conduz ao debate sobre a verdade para o campo do imprevisível: as pessoas sociais. Mesclando seus conhecimentos de Filosofia e Psicologia, defende a idéia de que o estudo da natureza humana, como por exemplo, o estudo das variedades, contribuiriam para uma "ciência da religião" e acreditava que a experiência religiosa envolve um domínio completamente sobrenatural. Instaurou-se, definitivamente, o termo "pragmatismo" e uma espécie de "movimento pragmático" conquistou o mundo todo a partir daquele momento.

Além de Peirce e James, outros nomes ainda foram importantes para a história da pragmática, como Willard Quine (1969), que em seus estudos sobre a "referência" defendeu a tese da "inescrutabilidade da referência", em que afirma que a referência é impenetrável, no sentido de que não se pode determinar "com segurança total" o alcance da expressão referencial no mundo.

Davidson (1986) e Rorty (1994) influenciados por James Dewey e L. Wittgenstein, defenderam a idéia de que se podem considerar as pesquisas dos fundamentos da linguagem como uma prática social contemporânea e fundamentaram a "teoria da coerência" que trata da coerência interna, e não a verdade, como o elemento que sustenta qualquer sistema interpretativo. A teoria da coerência se refere ao fato de que as atitudes proposicionais de uma pessoa, sua fala, crenças e intenções são verdadeiras, porque "existe um princípio legítimo que diz que qualquer das atitudes proposicionais do falante é verdadeira se é coerente com o conjunto de atitudes proposicionais desse mesmo falante". Davidson ainda considera que há um momento no diálogo em que nem sempre há coincidência de interpretação entre os participantes, ou seja, pode haver "malentendidos" - o que existe é simplesmente uma coerência interna nos sistemas interpretativos (Cf. PINTO, 2001, p. 54-55). 
O conceito de "mal-entendido" contraria uma idéia anteriormente discutida pelos estudiosos da linguagem sobre a questão de a comunicação sempre ser bem sucedida quando os falantes conhecem o mesmo código lingüístico. Efetivamente, nem sempre há uma comunicação plena entre os falantes, mesmo dentro de situações consideradas ideais, pois a interpretação correta do que se diz depende de fatores intrínsecos aos indivíduos, tais como: nível cultural, conhecimento lingüístico, se ambos compartilham os mesmos conhecimentos e experiências de mundo etc.

De acordo com Pinto (2001, p. 49), "o pragmatismo americano oferece, então, bases filosóficas para uma análise lingüística que relacione a todo momento signos e falantes, antes de qualquer coisa, compondo ambos o que se chama de fenômeno lingüístico". Dessa forma, representa, definitivamente, uma linha da filosofia que se volta ao concreto e adequado, aos fatos, à ação e ao poder.

O termo "pragmática" foi utilizado pela primeira vez em 1938, por C. W. Morris, quem a definiu como "a ciência dos signos em relação com seus intérpretes" e, desse modo, a pragmática passava a ocupar um lugar junto à semântica e à sintaxe (Cf. ESCANDELL-VIDAL, 1996, p. 7). Morris foi um filósofo e semiótico norte-americano para quem a linguagem se divide em três campos que correspondem às três relações fundamentais que mantêm os signos, a saber:
i) com outros signos (sintaxe),
ii) com o que designam (semântica)
iii) com seus usuários (pragmática).

Entretanto, foi J.L. Austin quem protagonizou um dos maiores avanços no estudo sobre a linguagem. Embora fosse um filósofo da linguagem, não chegou a utilizar expressamente o termo "pragmática" em suas aulas, conferências e seminários dos quais participou e cujos trabalhos foram reunidos postumamente, 
em 1962 e 1970 (Cf. ESCANDELL-VIDAL, op. cit., p. 43), mas, reconhecidamente, a sua obra How to do things with words foi a que mais influenciou os estudos da área da Lingüística e Filosofia da Linguagem.

A grande contribuição trazida pela obra de Austin foi a sua teoria sobre os atos de fala (posteriormente, foi melhorada pelo seu discípulo John Searle); e as concepções de ato locutório, ato ilocutório e perlocutório ${ }^{12}$.

Analisando a linguagem corrente, Austin fixou as bases da teoria dos atos de fala e afirmou que a linguagem serve não só para descrever o mundo, mas para fazer coisas. Dedicou-se, assim, a estudar a linguagem corrente e os aspectos do uso lingüístico e ressaltou a importância da linguagem ordinária - em contraposição à linguagem filosófica ou científica - que, a princípio, pode ser complementada, melhorada e substituída em qualquer lugar (Cf. ESCANDELLVIDAL, op. cit., p. 45).

Paul Grice (1967) discute sobre a diferença entre o que se diz e o que se comunica. Para o autor, não se pode acatar as expressões quando utilizadas na fala natural, como algo definitivamente aceitável, pois poderão ser ininteligíveis. Propõe, assim, uma língua ideal, determinada em um valor verdadeiro e livre de implicações metafísicas, em que o uso das expressões deve ter uma equivalência lógica. Considera que os equívocos nascem da não observação às regras que governam a conversação e que, nesse caso, o conceito de inferência ${ }^{13}$ introduz o de implicatura, ou seja, o que se diz corresponde basicamente ao conteúdo formal do enunciado; o que se comunica corresponde a toda informação que se

\footnotetext{
${ }^{12}$ Atos de fala: 1. Locutório - aquele que se realiza através dos sons emitidos pelo falante, mediante uma combinação de palavras em uma construção conforme uma gramática e dotada de significação. 2. Ilocutório - aquele que se realiza dizendo; corresponde ao valor ilocutivo da enunciação. 3. Perlocutório - aquele que se realiza pelo ato de dizer; corresponde ao efeito causado pelo dizer.

${ }^{13} \mathrm{O}$ conceito de inferência é largamente trabalhado pela lógica formal e trata-se de uma atividade de raciocínio - da qual a dedução e a indução são casos particulares - que diz respeito à passagem de uma proposição à outra quanto a seu possível valor de verdade, o que distingue a relação de inferência da relação de implicação. Esse conceito foi criticado por lingüistas, posto que na lógica formal não se considera o contexto em que se dá o enunciado. Para Ducrot, o ato de inferir consiste no ato de linguagem cuja realização implica produção de um enunciado (Cf. Charaudeau, P. e Mainguenau, D. (2004).
} 
transmite com o enunciado. Trata-se, portanto, de um conteúdo implícito. (GRICE, 1967, p. 24).

O conceito de implicatura levou Grice a estabelecer as regras da comunicação que intervêm na conversação. Segundo o autor, para o bom funcionamento da comunicação os falantes devem respeitar o Principio de Cooperação, cujo pilar de sustentação corresponde às quatro máximas que regem a linguagem humana (já mencionadas no capítulo I).

Mais tarde, Ducrot (1972), em sua obra Dire et ne pas dire recusa a concepção segundo a qual a língua serve para a comunicação - no sentido estrito da palavra, ou seja, como transmissão de informação. Ducrot considera que a língua comporta nela mesma todo um catálogo de relações inter-humanas, todo um arsenal de papéis, todo um dispositivo de convenções e de leis que regulam o debate dos indivíduos. Discute a língua e suas relações intersubjetivas e introduz os conceitos de posto (o que está explícito) e de pressuposto (o que está implícito).

Segundo Haberland \& Mey (1977), a pragmática analisa, por um lado, o uso concreto da linguagem, com vistas aos seus usuários e usuárias, na prática lingüística e, por outro, estuda as condições que governam essa prática.

Para Mainguenau (1990, p. 3), a pragmática permeia várias pesquisas que tratam do sentido e da comunicação e que vão do sociológico ao lógico. Portanto, muitas vezes pode ultrapassar o contexto do discurso e se tornar "uma teoria da ação humana" e, nesse sentido, não se apresenta como um estudo das frases como tipos, fora de um contexto (proposta saussuriana), mas "de ocorrências das frases" dentro de cada ato de enunciação.

Hoje se estuda a língua em conjunto com sua produção social e se considera o estudo da linguagem a partir dos conceitos de sociedade e 
comunicação. Além disso, os estudos se fundamentam na idéia de que os fenômenos lingüísticos não são puramente convencionais, mas compostos por elementos criativos, inovadores, que se alteram e interagem durante o processo de uso da linguagem. (PINTO, 2001).

Em suma, entende-se, hoje, por pragmática, "o estudo dos princípios que regulam o uso da linguagem na comunicação, ou seja, as condições que determinam tanto o emprego de um enunciado concreto por parte de um falante concreto em uma situação comunicativa concreta, como sua interpretação por parte do destinatário" (ESCANDELL-VIDAL, 1996, p. 14). Para tanto, os pesquisadores levam em consideração a existência de fatores extra-lingüísticos que determinam o uso da linguagem, tais como: emissor, destinatário, intenção comunicativa, contexto verbal, situação ou conhecimento do mundo.

\subsection{Uma nova corrente: a Análise da Conversação}

Compreender o que é e como se opera a linguagem foi o que motivou J.R. Firth, em meados do século passado, a afirmar que as respostas a essas duas perguntas somente viriam com o estudo profundo do discurso. A partir de então, o estudo interdisciplinar em torno ao tema foi ganhando cada vez mais relevância entre os pesquisadores, que foram tentando dar forma a diversas teorias da linguagem com base funcional pragmática, ou seja, desde a perspectiva da atenção ao uso que os falantes realizam das fórmulas que empregam em sua atuação lingüística; contudo, sem deixar de se relacionar também com outras teorias de base estruturalistas ou gerativistas. (Cf. VEZ-JEREMÍAS, 2004, p. 135)

Embora a sua base sejam os elementos pragmáticos envolvidos na interação, a Análise da Conversação $(A C)$ se difere da pragmática porque adota métodos diferenciados de análise e uma perspectiva sociolingüística. 
Alguns trabalhos, na década de 50, na área da sociolingüística - sobretudo no estudo de comunidades bilíngües - foram muito importantes para a análise do discurso (escrito e oral) e propiciaram as primeiras orientações para as pesquisas em AC.

Em 1966, Weinrich, Labov e Herzog, três sociolingüistas da época, apresentaram, no Texas, um importante ensaio intitulado Empirical Foundations for a Theory of Language Change, publicado, em 1968, no livro Directions for Historical Linguistics. Para Faraco, quem faz a apresentação da versão traduzida para o português $^{14}$ (WEINRICH; LABOV; HERZOG, 1968, p. 10), as pesquisas de Weinrich sobre as línguas em contato na região nordeste da Europa, as de Herzog no campo dialetológico, sobretudo o da interação dialetal, e as de Labov, que estabeleceu as bases metodológicas de pesquisa sociolingüística variacionista, além de trazerem à discussão a questão das mudanças lingüísticas e suas motivações sociais, convergiram para a publicação desse importante texto a partir do qual se estabeleceram novas bases para as teorias sociolingüísticas.

Esse trabalho mudou definitivamente a trajetória dos estudos sociológicos, na perspectiva da lingüística histórica, e estabeleceu novas diretrizes metodológicas para a análise da fala dos indivíduos de comunidades urbanas que possuem línguas em contato.

Historicamente, os estudos em torno à Análise da Conversação têm início por volta dos anos 60 , originários de trabalhos na área da Etnometodologia e Antropologia Cognitiva. A sua principal preocupação, até os anos 70 , foi com a organização do texto falado, ou seja, com a descrição das estruturas da conversação e seus mecanismos de funcionamento. Isso porque, para os etnometodólogos, como Harvey Sacks e Harold Garfinkel, o objeto de estudo da Etnometodologia é o estudo das práticas cotidianas dos indivíduos em uma

\footnotetext{
${ }^{14}$ Introdução apresentada pelo autor à versão traduzida de Carlos Bagno da obra: WEINRICH, LABOV, HERZOG. Empirical Foundations for a Theory of Language Change. In: LEHMAM, W. P.; MALKIEL, Y. (Ed.) Directions for Historical Linguistics - A Symposium. University of Texas, Austin/London, 1968, p. 95199.
} 
sociedade e, nessa linha de pesquisa, entende-se que essas atividades são processos que implicam uma realização estruturada, ordenada e metódica (ANDRADE, 1990:38).

O intuito inicial era o de oferecer uma noção do tipo de atividade que a conversação representa e de uma possível arquitetura textual. Os primeiros resultados levaram à conclusão de que a atividade da língua falada não é aleatória e tampouco desordenada e, portanto, é regida por regras.

Essa característica levou alguns autores, como Gullich (1987, p. 18) a propor o termo Análise Conversacional Etnometodológica. Mais tarde, outras linhas de investigação a ela se somaram - tais como: gramática da língua falada (ou gramática de uso), pragmática, atos de linguagem, análise do discurso (lingüística textual), sociolingüística, etnografia da comunicação e retórica originando 0 que conhecemos como Análise Conversacional Lingüística (ANDRADE, 1990, p. 39).

De acordo com Gallardo-Paúls (1998, p. 10) e Fuentes-Rodríguez (2000, p. 76) a pragmática teve um papel fundamental nesses estudos, em que se destacam a pragmática enunciativa (centrada no emissor); a pragmática textual (centrada no enunciado e sua organização interna) e a pragmática receptiva (centrada no receptor e no uso da linguagem em situações reais de interação). Além disso, ajudaram no desenvolvimento da $A C$, vários elementos de natureza diversa, tais como:

1. As críticas ao gerativismo (de Noam Chomsky) que, baseando-se na introspecção, não conseguia solucionar muitos dos problemas de ordem sintático-semântica;

2. A aparição da lingüística textual (Janos Petöfi, Teun Van Dijk) e sua defesa pelo estudo de uma unidade superior à oração, ou seja, o texto; 
3. As pesquisas desenvolvidas pelos teóricos da filosofia da linguagem (J. L. Austin, H. Paul Grice), que valorizam a utilização do código lingüístico para realizar ações e a teoria do ato de fala (e seus valores locutórios);

4. A psico e a sociolingüística (Joshua. A. Fishman) e a etnografia da comunicação (John J. Gumperz e Dell Hymes) que ajudam na descrição de situações extralingüísticas;

5. Algumas correntes sociológicas, especialmente a etnometodológica (Aaron Circourel y Harold Garfinkel; E.. Schegloff; E. Schegloff \& H. Sacks; W. Edmonson - que começam a valorizar o papel da linguagem na interação social e privilegiam a análise do turno e da seqüência.

6. A corrente psiquiátrica (Gregory Bateson, Paul Watlawick, Don Jackson) que alertam para a importância da linguagem como formuladora da realidade;

7. Aparição das primeiras escolas da análise do discurso falado, principalmente a de Birminghan (J. McH. Sinclair e Malcolm Couthard, Michael Stubbs, Margaret Berry) que consideram o discurso como um nível distinto ao da gramática, com suas próprias unidades e regras e que desenvolveram a teoria do movimento e intercâmbio na conversação;

8. Os estudos da corrente francesa (François Récanati, Oswald Ducrot) e, especialmente, a de Genebra (Eddy Roulet) e a lingüística interacional (Catherine Kerbrat-Orecchioni, Robert Vion), que trabalharam a idéia do intercâmbio, intervenção e ato; 
9. O desenvolvimento tecnológico que permite registrar textos orais de longitude teoricamente limitada.

Das áreas que contribuíram para a Análise da Conversação, ressaltamos a Lingüística Textual, cujos estudos desenvolvidos pelas várias correntes teóricas muito acrescentaram para a delimitação das tendências atuais de investigação do discurso falado.

Dentre os seus vários pesquisadores, mencionamos: Beaugrande \& Dressler, que traçaram os pressupostos da semântica procedural, Weinrich, que delimitou a macro-sintaxe do texto, van Dijk, que estabeleceu a macro e a microestrutura textuais; correntes americanas da análise do discurso que trabalharam com o processamento cognitivo do texto (conceito de compreensão e produção), os grandes lingüistas franceses que desenvolveram estudos no tocante à ordem textual e operacionalização das construções teóricas para o ensino de línguas, bem como a corrente socio-ideológica francesa.

A Lingüística Textual é aquela que considera o aspecto lingüístico e social. Há duas condições básicas para a existência de um texto:

$1^{\underline{a} .)}$ uma seqüência de signos lingüísticos coerentes em suas articulações sintático-semânticas;

$2^{\mathrm{a}}$.) a produção dessa seqüência em situação de comunicação.

Estuda não somente o texto, como também o contexto com a coerência suficiente para a compreensão.

Nos últimos anos, os processos cooperativos (interação) presentes na atividade conversacional estão sendo investigados. Para tanto, os especialistas 
procuram especificar os conhecimentos lingüísticos, paralingüísticos e socioculturais que devem ser compartilhados para que a interação seja bem sucedida (ANDRADE, 1990, p. 35). Com isso, os estudos na área têm proporcionado subsídios para a compreensão de ocorrências lingüísticas que antes não recebiam qualquer atenção ou mesmo uma explicação.

No Brasil, os estudos em torno da conversação começaram a ser realizados em 1968, através do Projeto de Estudo da Norma Lingüística Urbana Culta Falada no Brasil (NURC), inspirados no projeto do professor da Universidade Autônoma do México, Juan Lope Blanch, quem havia, em 1964, iniciado o Proyecto de Estudio Coordinado de la Norma Lingüística Culta de las Principais Ciudades de Iberoamérica y de la Península Ibérica. ${ }^{15}$ Desde o início, estabeleceu-se como critério que o Projeto NURC abrangeria as cinco principais capitais brasileiras com mais de um milhão de habitantes: São Paulo, Rio de Janeiro, Porto Alegre, Recife e Salvador. Consistiria em três etapas distintas: gravações, transcrições e análise do corpus e, este por sua vez, seria composto por gravações de quatro naturezas diferentes: gravações secretas, diálogo entre dois informantes, diálogo entre o informante e o documentador e elocuções formais.

Na Espanha, país que também integrou o projeto sobre a fala nas cidades de língua espanhola, destaca-se o Projeto VAL.ES.CO. (Valencia, Espanhol Coloquial) que tem como principal objetivo o estudo do espanhol falado em sua modalidade prototípica: a conversação coloquial. A pesquisa partiu de um corpus oral, extraído fundamentalmente da conversação espontânea (BRIZ-GÓMEZ; VAL.ES.CO., 2002, p. 11).

Esses estudos se desenvolvem no nível da oralidade, em situações de diálogo assimétrico (diálogo em que um interlocutor se sobrepõe ao outro) ou simétrico (diálogo espontâneo, em que os falantes dispõem de condições semelhantes para negociar livremente o assunto e controlar o turno). É importante saber que a Análise da Conversação se dá a partir de estudos empíricos em

\footnotetext{
${ }^{15}$ Informações obtidas através do site da Universidade de São Paulo: www.fflch.usp/DLCV/NURC
} 
situações reais de uso da língua - não apenas verbal, mas paralingüístico e suprasegmental (ou prosódico) - e que, portanto, é de caráter indutivo. Por isso, afirma Andrade (1990) que os seus alicerces encontram-se, historicamente, na etnometodologia, etnografia e sociologia.

A conversação, por sua vez, é, para Marcuschi (1986, p. 15), " a primeira das formas de linguagem a que estamos expostos e provavelmente a única da qual nunca abdicaremos pela vida afora"; constitui uma atividade básica do ser humano, e implica o envolvimento de duas pessoas, no mínimo, para sua realização. Como apontam Watzlawick et alii. (1998, p. 113), um sistema não pode ser considerado como a soma de suas partes, ao contrário, deve ser considerado como uma interação e, portanto, a conversação se desenvolve mediante a interação de seus locutores.

Outro aspecto importante diz respeito à modalidade de conversações a serem analisadas. É de senso comum que o ideal é que o corpus seja constituído de conversações espontâneas, por serem conversações naturais, não elaboradas e informais e, portanto, distantes do texto escrito, por ser este uma produção artificial, idealizada, inventada, introspectiva, intuitiva e hipotética.

Stubbs (1983, p. 46) afirma que o conceito de conversação natural não elimina a existência de uma organização textual, simplesmente deve ser entendida como uma organização diferente daquela da escrita. No entanto, considera que os termos que normalmente se utilizam para definir essas conversações nem sempre são sinônimos. Justifica sua afirmação apontando para algumas distinções que devem ser feitas sobre o conceito de discurso espontâneo, sendo a primeira entre

a) linguagem que se produz naturalmente, sem nenhuma intervenção do lingüista; 
b) linguagem que o lingüista provoca como parte de um experimento. Neste caso, estão incluídos os dados que são as próprias introspecções e intuições do lingüista, aquelas que obteve de si próprio.

Uma segunda diferenciação, deve ser feita entre:

a) linguagem espontânea, no sentido de que não está planejada, que se produz em um tempo real como resposta às exigências imediatas da situação (como a que resulta dos casos em que o lingüista provoca a conversação para um experimento);

b) linguagem que, deliberadamente, se planeja, se ensaia, se pensa, se modifica e se corrige.

c) aquela que caracteriza a maior parte da linguagem falada, incluindo-se a conversação habitual (como aquela que ocorre naturalmente, sem intervenção do lingüista);

d) aquela que caracteriza a maior parte da linguagem formal escrita.

Segundo o autor, poder-se-ia contestar que a conversação normal (a que surge naturalmente entre as pessoas) não está planejada por definição e que não pode ser planejada, que é relativamente imprevista, exceto a curto prazo em algumas ocasiões. Os tipos (b) e (d) normalmente coincidem, ou seja, os dados introspectivos são, em geral, conscientes sobre os que se reflete por um longo tempo com referência a um problema teórico concreto, o qual constitui uma limitação muito importante para utilizá-los como se fossem representativos do uso lingüístico normal. Para Stubbs (op. cit., p.47), muitos dos exemplos utilizados em lingüística se aproximam mais da linguagem escrita do que da falada, porque tanto a linguagem escrita como os dados introspectivos se inscrevem e se revisam nesses exemplos. Acrescenta, ainda, o autor, que esse é o grande 
problema de muitos dos dados da gramática gerativa, apesar de afirmar que estuda a linguagem, independentemente de suas variedades concretas. Admite, no entanto, que uma boa definição é dada por Ochs, em 1979 (Cf. STUBBS, op. cit., p. 47) que distingue entre discurso não planejado e discurso planejado. $O$ primeiro é o discurso que não foi pensado antes de ser expresso e tampouco preparado; o segundo é aquele que foi pensado e organizado antes de sua emissão. Entretanto, afirma que a maior parte do discurso falado oscila entre estes dois extremos e, portanto, convém falar de discurso relativamente planejado e relativamente não planejado. Assim, mesmo naqueles casos em que se contou uma história anteriormente, pode ser que a narração tenha sido planejada e ensaiada em seu conjunto, mas, desde logo, não se fez isso em todos os seus detalhes, posto que somente se concretizou no momento da conversação, frase a frase, levando-se em conta as exigências da interação social. Dessa forma, um discurso pode planificar-se, por exemplo, enquanto a função ilocutiva que realizará, sem que isto obrigue a planificar o conteúdo exato da emissão (GALLARDO-PAÚLS, 1998, p. 13).

As principais características de uma conversação não planejada, segundo Ochs (Cf. STUBBS, op. cit. p. 47), seriam: repetição freqüente, frases simples ativas com uma ordem de palavras não marcadas, construção conjunta de proposições nas emissões dos falantes, tendência a enlaçar orações coordenadas com alguns marcadores do tipo $\boldsymbol{e}$ preferentemente à construção de subordinações; justaposição de orações sem nenhum elemento de união explícito, argumentos e predicados que não estão unidos sintaticamente; omissão de referentes, incluídos os sujeitos das orações; a utilização de modificadores dêiticos em vez de artigos definidos; o uso de estruturas sintáticas desviadas à esquerda, nas quais o sintagma nominal sujeito vem seguido de um pronome correferente.

Algumas dessas características, segundo Stubbs (op. cit., p. 47), tomadas em conjunto, significam que "as relações semânticas entre proposições ou partes de proposições não estão indicadas explicitamente", podendo-se utilizar a justaposição ou emitir um elemento de informação. Por sua vez, esses traços não 
implicam que a linguagem falada não seja gramatical, ao contrário, apontam simplesmente para uma sintaxe diferenciada da maior parte da linguagem formal escrita.

Para Marcuschi (1986), a Análise da Conversação pretende responder a algumas questões importantes, tais como:

1) como as pessoas se entendem ao conversar;

2) como sabem que estão compreendendo-se;

3) como sabem que estão atuando de modo coordenado e cooperativo;

4) como usam os seus conhecimentos lingüísticos, paralingüísticos e socioculturais para obter condições favoráveis e adequadas à compreensão mútua;

5) como formam, desenvolvem e resolvem problemas durante a interação.

Para que se possa responder a essas questões, a A.C. utiliza os conhecimentos das áreas já mencionadas, sobretudo, dos estudos etnometodológicos, posto que estes trabalham de modo empírico, têm como principal objetivo descrever como os interlocutores organizam e desenvolvem suas intenções cotidianas sem se preocuparem com as causas desse procedimento e porque seu material de investigação está constituído de conversações produzidas em situações naturais.

Marcuschi ainda ressalta que a conversação se caracteriza, frente a outros tipos de discursos falados, por tratar-se de: 
1) uma interlocução presencial, face a face; imediata e atual - tempo e espaço são sincrônicos (aqui e agora);

2) uma conversação dinâmica, favorece a maior ou menor tensão dialógica e em que a tomada de turno não é determinada, mas os turnos podem se alternar entre falante/ouvinte;

3) uma modalidade em que existe a cooperação em relação ao tema conversacional e a intervenção do outro.

Para produzir e sustentar uma conversação, duas pessoas devem compartilhar um mínimo de conhecimentos comuns. E, entre eles, a aptidão lingüística, conhecimentos culturais e domínio de situações sociais.

Marcuschi (1986, p. 14), afirma que "quando conversamos, normalmente o fazemos com perguntas e respostas, ou então com asserções e réplicas". Entretanto, mesmo que haja o silêncio momentâneo dos interlocutores, ainda assim, haverá por trás uma intenção de se transmitir algum tipo de mensagem. Assim, estabelecem-se dois princípios da pragmática: o de não ser possível a "não comunicação", e o principio fundamental de Grice para a Análise da Conversação, o da cooperação entre os locutores para que haja interação.

Marcuschi afirma que, para que haja uma conversação, é necessário haver uma interação verbal centrada, ou seja, devem estar presentes:

a) interação entre pelo menos dois falantes;

b) ocorrência de pelo menos uma troca de falantes (caso contrário, estaríamos realizando um monólogo, sermão ou conferência); 
c) presença de uma seqüência de ações coordenadas;

d) execução numa identidade temporal;

e) envolvimento numa "interação centrada" (o que significa abrir-se para um evento cujas expectativas mútuas sejam montadas).

É importante que os interlocutores conheçam sobre o tema a ser discutido e que estejam de acordo em abordá-lo num determinado tempo e espaço. Andrade (1990, p. 44) aponta para a necessidade da existência das mesmas aptidões lingüísticas, do mesmo envolvimento cultural e domínio de situações entre os locutores. Só assim haverá conversação, efetivamente.

Os atuais estudos na perspectiva da Análise da Conversação mostram a importância das análises de elementos que estão presentes durante as enunciações. Temos, nesse sentido, avançado muito no que tange às questões de organização textual; coesão e coerência no texto falado, em que se estudam as trocas de turno, o tópico discursivo, os pares adjacentes (pergunta/resposta, convite/aceitação ou recusa, pedido/concordância ou recusa; saudação/saudação), os marcadores conversacionais, digressões; bem como as atividades de formulação, como correções, repetições, hesitações e paráfrases.

Para esta pesquisa, interessa-nos exclusivamente o estudo dos marcadores conversacionais como elementos importantes numa relação de atividade conjunta entre locutor e interlocutor para que se efetive a textualidade, pois, de acordo com Andrade (1990, p. 89):

(...) esses elementos são simultaneamente articuladores de funções ilocutórias reativas, distribuindo, em seqüências lineares os constituintes de uma troca e de funções interativas, estabelecendo hierarquias e revelando, ainda, a participação coletiva do locutor e interlocutor para a criação do "ato de fala comunicativo". 
Vale ressaltar que, numa dada conversação, estarão presentes o que Marcuschi (1986, p. 35) chama de pares adjacentes ou pares conversacionais, ou seja, seqüências em movimentos coordenados e cooperativos presentes de forma alternada dentro da conversação e que servem para sua organização local. São exemplos de pares conversacionais: pergunta-resposta; ordem-execução; conviteaceitação/recusa; cumprimento-cumprimento etc. Para Fávero, Andrade e Aquino (2006, p. 133), partindo-se do pressuposto de que a linguagem não é só uma atividade verbal, mas também social, esses elementos são cruciais na interação humana.

Marcuschi (1986, p. 36) salienta que

(...) sob o aspecto semântico-pragmático, os pares podem ser tomados como indícios da existência de compreensão ou pelo menos de uma compreensão existente, na medida em que a segunda parte do par só pode ser produzida se a primeira parte foi, de alguma forma, entendida. Assim, seja qual for a natureza significativa da segunda parte do par, ela é um indicador de como os falantes analisam suas contribuições.

Existe, portanto, uma "relevância condicional", em que os pares servem como organizadores ou selecionadores de falantes e proponentes de tema.

É preciso, entretanto, esclarecer que para outros autores a expressão semântico-pragmática refere-se a duas questões distintas. Embora a "fronteira entre semântica e pragmática seja normalmente traçada a partir da noção de contexto", para Moura (2000, p. 66) a "significação que independe de contexto é colocada no campo da semântica, e a significação contextualmente dependente é colocada no campo da pragmática". Em outras palavras, para a autora, o sentido (constituído no componente semântico) pode abranger diferentes elementos contextuais e nem todo elemento contextual deve ser considerado pragmático. Adota, portanto, a concepção de que "a pragmática envolve a atribuição de certas crenças ao interlocutor, que delimitam o contexto da interpretação. Os contextos que não dependem dessa atribuição de crenças não são pragmáticos, mas 
definidos no componente semântico, em função da dinâmica do discurso." (MOURA, op. cit., p. 76)

Ao lado dos elementos semântico-pragmáticos, encontramos uma íntima relação entre os elementos sintáticos e prosódicos. Por exemplo, numa conversação facilmente observamos a presença de alguns marcadores conversacionais verbais - lexicais ou não - acompanhados de elementos prosódicos. Este termo, afirma Scarpa (1999, p. 8)

(...) recobre, nos estudos lingüísticos, uma gama variada de fenômenos que abarcam os parâmetros de altura, intensidade, duração, pausa, velocidade de fala, bem como o estudo dos sistemas de tom, entoação, acento e ritmo das línguas naturais, gama esta que demanda enfoques especializados aos fatos considerados.

De acordo com Pereira, Mata e Freitas (1992, p. 27), a análise prosódica descrita por J. R. Firth, nos anos 40, na Inglaterra, traz a originalidade de considerar "as dimensões sintagmática e associativa, assim como as noções de estrutura e sistema, referindo-se estrutura às relações sintagmáticas e sistema aos paradigmas de elementos contrastivos relevantes nas várias posições numa estrutura". Para os autores, a análise prosódica proposta por Firth consiste na análise do material fônico que pertence a estruturas mais longas que o segmento e à análise dos traços que, "não se realizando foneticamente sobre a totalidade de uma estrutura, servem para delimitar, entrando em relações sintagmáticas com o que precede ou segue". Dessa forma, análise gramatical e fonológica são interdependentes para o autor.

$\mathrm{Na}$ conversação espontânea não raramente encontramos os elementos prosódicos associados a vários elementos semântico-pragmáticos e sintáticos. Nesta pesquisa, a interface entre aqueles elementos e os marcadores conversacionais é discutida, posto que ao analisar a produção oral de lusofalantes aprendizes de espanhol, observamos empiricamente que em todas as 
situações de interação há uma presença muito forte de marcadores que variam de acordo com a competência lingüística do aprendiz e que parecem influenciar não somente a fluência da língua como a aprendizagem da sua entoação. Ainda que o aprendiz se utilize de um marcador da língua materna na produção oral da língua estrangeira, no caso o português, parece ser através dele que consegue manterse falando no idioma estrangeiro (inclusive como aviso de que está trocando o código lingüístico) e garante, com isso, não somente a interação como também mantém o turno de fala e protege a sua imagem positiva em relação ao outro mostrando um certo domínio e poder durante a conversa.

Sendo assim, os trabalhos na área da Análise da Conversação ou Análise do Discurso Falado são importantes para a compreensão da natureza da interação humana e oferecem subsídios para a análise do uso dos marcadores no processo aquisição / aprendizagem de línguas e no desenvolvimento de competências conversacionais.

\section{Os marcadores conversacionais}

\subsection{Origem dos estudos sobre marcadores conversacionais}

O presente trabalho tem mostrado a unanimidade entre os pesquisadores da área da Análise da Conversação no que se refere ao fato de o texto falado não se distanciar do texto escrito, enquanto estrutura e organização, haja vista a presença de vários elementos sintático-semânticos e pragmáticos nos discursos falados e os diferentes procedimentos e estratégias adotados pelos falantes para desenvolver uma conversação da forma mais coerente e coesa possível, bem como para assegurar-Ihe compreensibilidade e interesse. Assim, a diferença está nas unidades da comunicação que devem seguir princípios comunicativos e não meramente sintáticos (MARCUSCHI, 1986, p. 61). 
Castilho (2000, p. 29) comenta que "a conversação é uma atividade lingüística básica" e "integra as práticas diárias de qualquer cidadão". Está sempre associada a uma intenção, ao principio de participação e cooperação e, evidentemente, na dependência de pelo menos dois interlocutores. Analisando-se as inter-relações entre os falantes, observamos a presença de alguns elementos semântico-pragmáticos verbais, não-verbais e prosódicos que estão presentes nos discursos orais e que são responsáveis pela sua organização, funcionando como conectivos textuais: são os chamados Marcadores Conversacionais.

Vários autores têm-se dedicado amplamente ao estudo desse tema nas últimas décadas. Said Ali, em 1930, foi um dos primeiros a estudá-lo, embora não aplicasse, naquele momento, o termo "marcador". A partir de uma perspectiva lógico-gramatical, o autor menciona a existência de palavras e frases no falar corrente, em especial nos diálogos, que se expressam espontaneamente, "mas não a esmo, e sim em determinadas condições". Acrescenta, também, que não são desnecessárias, pois ao eliminá-las, as proposições parecem perder a capacidade de expressar o intuito que se quer manifestar (SAID ALI, 1930, p. 49).

Como vemos, o autor já considerava que essas "palavras e frases" constituíam elementos importantes para a compreensão da conversação e para que a intenção do locutor fosse alcançada. Relacionou-as às exigências da situação de comunicação e à necessidade de expressão emotiva, ou seja, seu uso estaria na dependência de uma situação específica em que o locutor tivesse uma intenção bem delimitada com relação ao seu interlocutor, bem como estariam em jogo também os aspectos emocionais, uma vez que isso faria com que alguns elementos da conversação fossem alterados, como por exemplo, o tom. Preferiu chamá-las de expressões de situação, e não de palavras expletivas ou palavras de realce, como muitos gramáticos as denominavam (GONÇALVES, 2000).

De certa forma, Said Ali antecipava o que a pragmática e, em especial, Austin, anos mais tarde, viria defender: a força ilocutiva das palavras. O autor brasileiro mencionava a "força" ou "energia" que essas palavras adquirem na fala 
- não no falar "eloqüente e retórico", mas no falar cotidiano - promovendo, assim, alteração no valor da frase, sobretudo, quando se tem que "ajeitar a cada momento a linguagem em atenção a essa pessoa que está diante de nós" (SAID ALI, 1930, p. 50-51).

Said Ali (op. cit., p. 50) considerou, assim, a intenção do locutor e as "varias cambiantes de situação existentes no diálogo, na conversação, no trato familiar, que determinam o uso dessas expressões concisas, alheias, talvez à parte informativa, mas capaz de conseguir intuitos que palavras formais não conseguiriam" - ou seja, as diferentes situações possíveis em que um locutor pode encontrar-se com seu interlocutor. Por isso denominou-as "expressões de situação". Foi além disso, comentou ainda que nem sempre há a necessidade de introdução de vocábulos e frases de propósito na oração; às vezes basta a substituição de uma forma gramatical por outra ou, simplesmente, o silêncio, a pausa e a reticência (SAID ALI, op. cit., p. 51). Acreditava que o uso desses recursos de linguagem não era fruto do acaso mas que estava no domínio do subconsciente, e que nem o "orador" (como denominava o locutor) nem o ouvinte (alocutário) os analisavam, mas os usavam e percebiam com presteza (SAID ALI, op. cit. p. 52).

Há mais de setenta anos, portanto, esse autor já compreendia a linguagem oral sob outro prisma. Suas análises da oralidade se aproximavam muito das que hoje realizamos. Aquelas expressões de situação são hoje chamadas de marcadores conversacionais e seu trabalho foi o ponto de partida para os estudos de muitos pesquisadores. Já compreendia que os recursos de linguagem que mencionou não poderiam ser meramente expletivos ou de realce e, de fato, hoje sabemos que se tratam antes de estratégias criadas pelos falantes durante a interação conversacional, a fim de obterem sucesso na comunicação.

Ynduráin (1964, p. 2) utilizou o termo muletilla ${ }^{16}$, referindo-se a essas palavras sobre as quais vamos descansando e tomando impulso enquanto

\footnotetext{
${ }^{16}$ Muletinha, em português. Tradução nossa.
} 
falamos. Um ano mais tarde, Ynduráin (1965, p. 3) traz uma nova definição, referindo-se a elas como palavras desprovidas ou despojadas de sentido que servem como mero suporte na conversação.

Keller (1979) chama os marcadores conversacionais de gambitos e aponta que, geralmente, aparecem no início do enunciado e que são sintaticamente dele independentes. A partir de uma análise psicolingüística, Keller identifica estratégias verbais usadas na estruturação do discurso: observa que os gambitos podem ter uma participação mais útil na análise do texto conversacional, porque indicam a estrutura geral do tópico a ser abordado (natureza geral da informação semântica transmitida), bem como os vários sinais sociais, psicológicos e comunicativos usados no fluxo discursivo. Nessa perspectiva, a polidez é a característica regente dessa estruturação.

Schiffrin (1982) também concorda que são elementos que aparecem tipicamente em posição inicial e que são sintática e semanticamente independentes do enunciado; contudo, são seqüencialmente dependentes dos enunciados anterior e posterior à sua realização. Para denominá-los, introduz o termo marcadores do discurso (discourse markers)..

Lope Blanch (1983, p. 160) também os denomina muletillas, considerandoas "vazias de conteúdo específico, formas ocas, de diversa natureza e de distinta função" e Ihes atribui um certo valor retardatário por considerar que o falante se utiliza dessas palavras ou frases para ganhar tempo na organização mental da sua elocução e selecionar as estruturas correspondentes, além de exercerem outras funções tais como a de amparar vacilações expressivas da língua espontânea e manter a atenção do interlocutor.

Roulet et alii (1985) utilizam o termo conectores pragmáticos e dizem que podem ser subdivididos em três tipos: os marcadores da função ilocutória, os marcadores de função interativa e os marcadores de estruturação da conversação. Ao mesmo tempo, esses conectores apresentam duas funções: 
organizam os quadros discursivos em seus alcances e hierarquias ao articularem as relações interpessoais; e, como estruturadores contextuais, asseguram o desenvolvimento progressivo do discurso, atuando simultaneamente no plano enunciativo como meta-operadores. Assim, os marcadores dão seqüência às unidades na ordem sintagmática, pois segmentam e ligam partes do texto.

Silva (1987, p. 392) adota o termo marcador para referir-se ao uso de certas expressões de emprego espontâneo muito freqüentes no falar corrente e relativamente fixas na sua forma, termo oriundo de pesquisas do comportamento humano para indicar os sinais de mudança de comportamento que acompanham a segmentação da ação.

Para Castilho (1987), são sintaticamente independentes do verbo, ocorrem no inicio, meio ou final dos turnos e funcionam no monitoramento da fala, na modalização do conteúdo do que se vai dizer, ou mesmo para chamar a atenção do interlocutor, mantendo-o preso à conversação. Sua independência sintática implica serem descartáveis sem prejuízo da construção sintagmática em si. Contudo, são discursivamente dependentes e suas funções variam dentro/entre os diferentes discursos. Mais tarde, o autor os definiu como elementos que "verbalizam o monitoramento da fala, sendo freqüentemente vazios de conteúdo semântico, portanto, irrelevantes para o processamento do assunto, porém altamente relevantes para manter a interação" (CASTILHO, 2000, p. 47).

Martín-Zorraquino e Montolío-Durán (1988) empregam o termo marcadores do discurso, considerando, entretanto, outras denominações possíveis: conectores, operadores pragmáticos, ordenadores do discurso, enlaces extraoracionais, elementos de coesão etc. Podem ser estudados sob várias ópticas teóricas e, em cada uma delas, revelam um caráter e funções particulares.

Ao analisar as muletillas, Narbona-Jiménez (1989, p. 166) comenta que, apesar de muitas vezes funcionarem como muletas de escasso poder articulatório, 
não podem ser consideradas como elementos supérfluos ou de preenchimento, pois atuam como verdadeiros elos no encadeamento textual.

Marcuschi (1989, p. 282) diz que os marcadores conversacionais são "palavras e expressões mais ou menos fixas, características da fala, elementos que operam, simultaneamente, como organizadores de interação, articuladores do texto e indicadores da força ilocutória, sendo, pois, multifuncionais". Dão coesão ao texto, mas também o segmentam, agindo como fatores de segmentação e suprimindo em boa medida o papel da pontuação da fala. São mais ou menos fixos e freqüentes, o que garante o processo de coesão e segmentação. $O$ autor trata os marcadores conversacionais tanto em suas propriedades interacionais (na condução dos atos ilocutórios e das relações interpessoais) como em suas propriedades intratextuais (na estruturação da cadeia lingüística). A rigor, comenta que isso supõe que o uso da língua na interação verbal ocorre com a aplicação de princípios pragmáticos e de regras lingüísticas e, dessa forma, operam simultaneamente, como organizadores da interação, articuladores do texto e indicadores de força ilocutória, sendo, pois, multifuncionais. Adquirem, portanto, a função de conectores pragmáticos.

Andrade (1990, p. 101) define os marcadores conversacionais como sendo "conectores interativos e não só conectores textuais", pois "eles existem devido às funções interacionais, já que estas comandam estratégias adotadas pelos interlocutores na construção e manifestação de suas identidades sociais. Essas funções ganham existência através de esquemas lingüísticos rotineiros e estereotipados, dependendo, geralmente, de fatores e variáveis socioculturais." Para a autora, as funções irão variar de acordo com a necessidade de se preservar a face negativa e positiva do interlocutor ou do próprio locutor, dentro de um comportamento cooperativo que regula e garante o processo interacional. Desse modo, os interlocutores "investem em um dado esquema de marcador conversacional e agem de acordo com suas intenções", tais como: disponibilidade para negociar, abrandamento de posição, proposta de oferta de um tema para consideração etc. 
Para Rosa (1992, p. 16), a observação da linguagem nas interações face a face do dia-a-dia aponta imediatamente para a alta freqüência de determinadas palavras ou expressões lingüísticas mais ou menos convencionalizadas. Essa idéia corrobora a de Tannen $(1985$, p. 3) que adverte que todo significado na linguagem deriva, pelo menos parcialmente, de convenção.

Segundo Urbano (1993, p. 86), marcadores conversacionais são elementos típicos da fala, dotados de grande freqüência, recorrência, convencionalidade, idiomaticidade e significação discursivo-interacional e marcam sempre alguma função interacional na conversação, ou seja, são elementos que amarram o texto não só enquanto estrutura verbal cognitiva, mas também enquanto estrutura de interação interpessoal. O mesmo autor comenta (1993, p. 85) que esses marcadores não integram propriamente o conteúdo cognitivo do texto e que são meramente elementos que ajudam a construir e a dar coesão e coerência ao discurso falado, funcionando como articuladores não só das unidades cognitivo-informativas do texto como também dos seus interlocutores, revelando e marcando as condições de produção, naquilo que ela representa de interacional e pragmático.

Christl (1996, p. 117) também adota o nome muletinhas e as divide em dois grupos: o primeiro, com função retardatária e, o segundo, com função de organizadores do discurso, importantes para a realização de uma conversação.

Briz-Gómez (1998, p. 165) utiliza a expressão conectores pragmáticos porque considera que não são somente enlaces de conexão enunciativa, mas marcas da estrutura da conversação e de sua progressão coerente. O autor explica que, quando na conversação, se rompe o fio continuo da anáfora, alguns destes conectores são mecanismos reguladores que o religam; a eles se agarra o falante em outras ocasiões para reter, recuperar ou roubar o turno etc. Como articuladores ou elementos de transição das unidades de fala, os conectores pragmáticos funcionam, tanto no plano local como no plano global da conversação, como instruções da atividade argumentativa dos interlocutores e/ou 
como traços de atividade formulativa e conversacional. Segundo o autor, na nomenclatura espanhola também abundam termos que o designam, tais como: expressões de preenchimento, muletinhas, bordões, apoios lexicais, elementos expletivos, fórmulas retardatárias; já no nível supra-oracional, podem ser chamados de enlaces extra-oracionais, ordenadores discursivos, enlaces conjuntivos, suportes conversacionais (ou enlaces coloquiais, nexos temáticos), conectores paragráficos ou extra-oracionais, embora, adverte o autor, nem sempre referidos aos mesmos fenômenos que com eles se pretende diferenciar.

Risso, Silva e Urbano (2006, p. 427) sublinhan que:

(...) o acompanhamento do fluxo discursivo em textos de língua falada revela a presença de um conjunto de palavras ou locuções envolvidas no amarramento textual das porções de informação progressivamente liberadas ao longo do evento comunicativo e, simultaneamente, no encaminhamento de perspectivas assumidas em relação ao assunto, no ato interacional.

Referem-se a essas palavras ou locuções como unidades articuladoras que organizam o texto, participando diretamente do desenvolvimento do tópico discursivo quer seja no movimento de início, fechamento ou evolução.

Como se observa, o estudo dos marcadores conversacionais tem crescido ao longo dos anos e transformado a análise da conversação em objeto de interesse de muitos pesquisadores. Aquelas partículas que a princípio eram consideradas somente como expletivas hoje são reconhecidas como elementos presentes na conversação, com funções variadas e que, embora independentes sintaticamente, são dependentes discursivamente (GONÇALVES, 2000, p. 50) Ou seja, ao se analisar a comunicação desde o ponto de vista da análise da conversação, faz-se mister considerar as relações interpessoais entre os interlocutores do discurso falado. Entendemos, também, que a interação verbal depende da necessidade de se preservar a face, disponibilidade para negociar, troca de turno, desenvolvimento do tópico discursivo etc, mas que a base de toda ela é o próprio desejo de manifestação dos falantes - incluídas as expressões 
afetivas, interesses e intenções que estão por trás da negociação entre eles no momento da produção conversacional.

\subsection{Perspectivas atuais para 0 estudo dos marcadores conversacionais}

A trajetória dos estudos sobre marcadores conversacionais ao longo dos últimos setenta anos mostram que, se antes eram vistos com certa indiferença pela gramática tradicional, hoje são o foco de interesse de um número considerável de pesquisadores, pois, ao compreender-se o discurso falado como produto da interação humana, esses elementos passam a ocupar um lugar privilegiado no desencadeamento de alguns fenômenos conversacionais advindos da necessidade de cooperação e compreensão no momento da elocução.

Sem dúvida, analisar os marcadores conversacionais significa compreender que a conversação traz em si todas as noções de cooperação e, por tanto, de interação. Através desses elementos podemos observar como os interlocutores negociam entre si, como protegem suas faces, como elaboram seus pensamentos, como reagem ao que ouvem, que intenções apresentam durante 0 ato; enfim, é descobrir um pouco como se organiza, em termos de planejamento, o texto falado e como é levado a cabo pelos envolvidos (GONÇALVES, 2000, p.73).

Assim, na perspectiva textual-interativa, os estudos na área da análise conversacional avançaram muito, nos últimos anos, no sentido de se tentar explicar cada vez mais e melhor como esses elementos se manifestam e como atuam nos processos de negociação entre os interlocutores do diálogo.

Consideramos, assim, marcadores conversacionais algumas unidades ou recursos que permitem a construção e a organização do discurso e que são imprescindíveis para o texto falado. Esses recursos podem ser subdivididos em 
três tipos de evidências: a) verbais (lexicais ou não lexicais), b) não verbais ou paralingüísticos (o olhar, o riso, os movimentos de cabeça, a gesticulação) e c) supra-segmentais ou prosódicos (MARCUSCHI, 1986, p. 61). Para o autor,

Existem relações estruturais e lingüísticas entre a organização da conversação em turnos (marcados pela troca de falantes) e a ligação interna em unidades constitutivas de turno. Isto sugere que os marcadores do texto conversacional são específicos e com funções tanto conversacionais como sintáticas. (MARCUSCHI, op. cit., p.61)

Diz-nos Marcuschi (1986, p. 72) que a presença de marcadores associados a elementos prosódicos sugere uma íntima relação da "sintaxe da interação com a sintaxe gramatical".

Por sua vez, alguns estudos de prosódia sugerem, de acordo com Scarpa (1999, p. 253-254), a existência de uma prosódia que preexiste ao léxico e à gramática, ou seja, os padrões prosódicos já estariam estabelecidos e minimamente estruturados. Outros guardam um certo caráter biologizante, e defendem a "naturalidade" de fenômenos prosódicos, tais como o ritmo e a melodia presentes na fala de crianças pequenas. Outros, por sua vez, invocam a prosódia como evidência de conhecimento prévio e outros, ao invés de primitiva e pronta, vêem-na como construída. Entretanto, a autora ressalta que,

(...) quanto à questão do conhecimento sintático prévio, pode-se pensar como alternativa a hipótese de que a prosódia molda a materialidade fônica em organizações e reorganizações sucessivas. A criança pequena trabalha com a organização do significante, delimitando-o e segmentando-o. A prosódia, por ser não discreta e por ser constituída de subsistemas potenciais (altura, intensidade, duração, velocidade da fala, ritmo, pausa) e, portanto, menos "fechados" que os sistemas gramaticais ditos nucleares, é um bom caminho para a configuração da forma fônica, não apenas como matéria sonora, mas como matéria significante, isto é, simbolizável e passível de significação. O trabalho sintático é, assim, concomitante com o fônico, integrado a ele, influenciando-se mutuamente. (SCARPA, 1999, p.258) 
Os diversos exemplos dos projetos de fala desenvolvidos até hoje (NURC, Val.Es.Co.) nos mostram que muitas das estruturas lingüísticas envolvidas no processo de conexão entre os turnos ou entre as unidades que o constituem podem atuar com uma dupla função: por um lado, tratam-se de operadores ou conectivos naturais, as chamadas partículas invariáveis do discurso (conjunções, preposições, advérbios) que exercem uma função sintática, ou outra que, dentro do contexto de fala, não se situa exatamente numa perspectiva sintática, mas semântica e interacional, ou seja, uma função comunicativa.

Nesse sentido, atualmente alguns autores fazem uma distinção, no que se refere à nomenclatura atribuída a esses elementos, com relação a suas funções. Segundo Martín-Butragueño (2006), baseando-se na proposta feita, em 1999, por Martín-Zorraquino e Portolés-Lázaro, seguidores de uma corrente denominada pragmalingüística ou pragmagramática, os marcadores podem classificar-se da seguinte forma:

1. Estruturadores da informação: tanto aqueles que são utilizados para fazer comentários (pois/pues), como os ordenadores de abertura (primeiro/primero) ou, ainda, os ordenadores de continuidade (logo/luego);

2. Conectores: nesta categoria estariam presentes as conjunções
a) aditivas (além disso/ además);
b) Consecutivas (então, pois/entonces/pues);
c) Contra-argumentativas (entretanto/sin embargo);

3. Reformuladores: conjunções explicativas (ou seja/ o sea); 
4. Operadores argumentativos: aqueles utilizados para a concretização do pensamento (por exemplo, acredito que/por ejemplo, creo que);

5. Marcadores conversacionais:

a) de modalidade epistêmica - cuja função é, por exemplo, reforçar a asserção, desenvolver cortesia positiva (claro/claro)

b) de modalidade deôntica, enfocador de alteridade, (bom, veja, você sabe, que vou dizer/bueno, mira, ya sabes, qué te diré)

c) meta-discursivo (em português, encontra-se, por exemplo: como você falou/ em espanhol é comum: este)

Outros pesquisadores também fazem distinção entre marcadores conversacionais e operadores discursivos, mediante o fato de os primeiros desempenharem um papel no discurso conversacional e os segundos referiremse, também, às suas funções na operacionalização frasal tanto na fala como na escrita. No caso dos marcadores conversacionais, não se descarta o seu papel de conector textual, nem suas funções gramaticais no contexto oral, embora Frase, em 1990, tenha isolado os marcadores discursivos de conjunções e advérbios homônimos e rejeitado, assim, a existência de vínculos conteudísticos com esses vocábulos gramaticais (apud. RISSO, 1996, p. 447).

Por sua vez, Christl (1996) estabelece a seguinte tipologia:

1. Marcadores com função expletiva: marcadores que representam grandes hesitações dentro da fala;

2. Marcadores com função comunicativa: aqueles que promovem

a) o avanço da conversação (dando apoio ou assentimento); 
b) uma relação mais íntima (fazendo com que o interlocutor agregue novas informações a seus conhecimentos de mundo);

3. Marcadores com função expletiva e comunicativa: aqueles que ajudam a:

a) ganhar tempo para a formulação;

b) assinalar compreensão;

c) re-introduzir tópico depois de digressão;

Ainda de acordo com esse autor, os marcadores de função comunicativa podem ser:

a) de início - quando introduzem enunciados

b) de reformulação - marcam uma relação parafrástica

c) de correção - sintática ou semântica

d) terminativos - assinalam o final do enunciado (manifestando aprovação, transferência de turno, confirmação ou negação de um ato de fala, cortesia). Também promovem a participação do outro e mantêm a atenção do interlocutor.

Por fim, Christl faz uma classificação em torno à atuação dos marcadores, especificando que podem ser de forma retardatária ou de modo a promover a participação ativa no discurso.

Briz-Gómez (1998) classifica os conectores pragmáticos, de acordo com sua função, em: 
a) conectores argumentativos (fazem a conexão e a argumentação) - por sua relação semântico-argumentativa dentro das unidades monológicas que pode ser de ordem sintático-proposicional ou pragmática;

b) conectores metadiscursivos (promovem a conexão e a formulação) por fazer parte de uma estratégia de negociação, que pode ocorrer mediante a intenção de formular, reformular e avançar a conversação. Isso quer dizer que participam diretamente da organização da atividade discursiva, inclusive como tentativa de se evitarem as contradições, ao mesmo tempo em que demonstram controle da mensagem por parte do falante e o controle mutuo que exercem os participantes entre si.

A divisão realizada por Briz-Gómez se faz mediante a proposta de se estudar como se processa a articulação dos enunciados da língua falada, ou seja, de que modo se constitui a coerência do texto falado.

Para Marcuschi (1986, p. 61), os marcadores desempenham, no discurso falado, tanto uma função sintática como conversacional e podem constituir não somente uma estrutura lexical como também frasal. Nesse sentido, é comum encontrar marcadores formados por locuções ou frases completas: frases de infinitivo com valor temporal, condicional ou de outro tipo; predicativos absolutos, comentários oracionais, amplificadores, ordenadores do discurso (MARTíNZORRAQUINO e MONTOLÍO-DURÁN, 1988, p. 24).

Segundo Marcuschi (1989, p. 290), os marcadores podem ser simples, compostos, oracionais ou prosódicos, de acordo com a sua estrutura constitutiva.

$\mathrm{Na}$ amplitude das possibilidades em que podem apresentar-se dentro de um texto conversacional, podemos definir os marcadores como um grupo heterogêneo de elementos de variada estrutura gramatical que se distinguem por suas funções semântico-pragmáticas e se dedicam a precisar, contrastar, 
confirmar o significado da oração, a marcar a sua ordem e relação com uma oração ${ }^{17}$ anterior ou posteriormente enunciada durante o ato conversacional, ou ainda iniciar, acompanhar, finalizar ou dar continuidade (fazer com haja avanço) aos turnos conversacionais (intra ou inter-turnos). Adquirem, portanto, um precioso valor no processo interacional.

Baseando-se em linhas teóricas alemãs, como à de Rath, do final da década de setenta, Marcuschi (1986, p. 62) parte da premissa de que "tanto na produção oral como na escrita o sistema lingüístico é o mesmo para a construção das frases, mas as regras de sua efetivação bem como os meios empregados são diversos e específicos, o que acaba por evidenciar produtos lingüísticos diferenciados".

Essa característica nos ajuda a compreender os processos de descategorização pelos quais passam ou passaram os conectores, ou seja, de modificações na estrutura morfossintática, na mobilidade e no alcance estrutural de alguns deles ao longo da história da língua. Martín-Zorraquino (1988, p. 211) mostra o caso de "sin embargo" e de "no obstante" em espanhol, em que a sua gramaticalidade pode ser explicada a partir de mecanismos cognitivos como a metáfora e a metonímia e que não são processos evolutivos fortuitos, senão cognitivamente motivados. Para a autora, a evolução dos conectores - nesse caso, especificamente os contra-argumentativos, tem importantes repercussões semânticas, pelo que supõe o aparecimento de umas partículas com claro valor discursivo, assim como sintático.

Nessa perspectiva analítica, Risso, Silva e Urbano (2006, p. 430) ressaltam as diferenças sintático-semânticas de alguns advérbios quando no papel de marcadores do discurso. É o caso do advérbio "agora" que, categorizado inicialmente como um advérbio temporal, pode exercer uma função pragmáticotextual distante da sua função de origem. Dessa forma, advertem (op. cit., p. 432)

\footnotetext{
${ }^{17}$ Vale ressaltar que Marcuschi (1986) considera o termo Unidade comunicativa (UC) como substituto, dentro de um contexto conversacional, ao que seria "frase" ou "oração" para a gramática tradicional.
} 
que "essa diversidade de papéis da forma "agora" como advérbio ou marcador, suscita as seguintes questões: a) a definição do estatuto semântico de "agora" enquanto advérbio temporal e b) a identificação das propriedades pragmáticotextuais que particularizam o "agora" enquanto marcador da estrutura tópica". Essas questões, no entanto, somente podem ser avaliadas mediante a análise das suas funções no discurso oral, mas reforçam os estudos anteriores de Risso (1996, p. 423-451) quando, ao estudar o marcador "então", apontou para o fato de ele transitar entre uma e outra instância de atuação:

(...) atrás das mencionadas formas gramaticais polivalentes, registram-se elos sintático-semânticos que nos permitem considerar, em cada caso, um "continuum" entre a conjunção e o advérbio, no âmbito frástico, ou como articulador, no âmbito das relações textuais, sem prejuízo de aquisição de novos valores semântico-pragmáticos (...)

Dessa forma, "então", no âmbito da conversação, caracteriza-se tipicamente como um articulador de partes do texto, explica Risso. A autora, diante da perspectiva integrativa que assume, conclui que se forma, portanto, um conjunto entre o teor pragmático e o cognitivo-conteudístico da informação, com a possibilidade de que um se sobressaia ao outro, dependendo da natureza do evento comunicativo em pauta; que há afinidades entre especificidades estruturais e coesivas de "então", em seus diferentes enquadramentos e abrangências e que há assentamento dessas afinidades na expressão de uma temporalidade (dos fatos ou da organização discursiva) ou na sinalização de uma interdependência dedutivo-conseqüencial entre segmentos da frase e do texto; e, por fim, há uma ancoragem anafórica em instância frasal ou tópica preliminar, como propriedade básica geral, envelopante de todos os empregos.

Por sua vez, Rosa (1992) já abordava a descategorização de alguns advérbios, como "bem" dentro do contexto conversacional, classificando-os, discursivamente, como marcadores de atenuação, para os casos analisados, como recursos destinados à preservação da face numa interação verbal. 
Segundo a autora, em seus estudos puderam ser encontrados marcadores de atenuação de diferentes funções e tipos, baseando-se na natureza pragmáticointeracional, a saber:

\begin{tabular}{|c|c|}
\hline Função & Tipo \\
\hline Marcador de emolduramento & $\begin{array}{l}\text { 1. de opinião (para mim...) } \\
\text { 2. metadiscursivo }{ }^{18} \text { (eu gostaria } \\
\text { de acrescentar o seguinte...) }\end{array}$ \\
\hline Marcador de modalização & $\begin{array}{l}\text { 1. de opinião (acho que...) } \\
\text { 2. hedge }{ }^{19} \text { (talvez...) }\end{array}$ \\
\hline Marcador de anúncio & $\begin{array}{l}\text { 1. metadiscursivo (eu vou desde } \\
\text { o início... declarar que...) } \\
\text { 2. de opinião (a impressão que eu } \\
\text { tenho...) } \\
\text { 3. rejeição (eu não sei se a } \\
\text { analogia está certa mas...) }\end{array}$ \\
\hline Disclaimer & $\begin{array}{l}\text { 1. de rejeição (se não estou } \\
\text { enganado...) }\end{array}$ \\
\hline Distanciamento & $\begin{array}{l}\text { 1. de distanciamento (parece que não } \\
\text { é...) }\end{array}$ \\
\hline
\end{tabular}

A perspectiva atual para o estudo dos marcadores conversacionais abrange estudos pragmagramáticos, segundo a denominação sugerida por Briz-Gómez (1998) em que, desde uma linha teórica textual-interativa, se analisa o marcador a partir da sua função no discurso, relacionando aspectos sintático-semânticos aos pragmáticos. Nessa orientação, vimos que alguns autores já desenvolveram estudos interessantes, como Rosa (1992), Briz-Gómez (1998), Risso (1996),

\footnotetext{
${ }_{18}$ Marcador que contem frases declarativas.

${ }^{19}$ De acordo com Rosa (1992, p. 48), hedge é um termo introduzido por Brown e Levinson, em 1978 e representa aqueles advérbios, locuções adverbiais, expressões verbais, pequenas frases etc. que introduzem um grau de incerteza ou de imprecisão nos enunciados em que ocorrem.
} 
Romera (2003), Risso, Silva e Urbano (2006) em que se analisam as descategorizações das conjunções, advérbios e outros elementos sintáticos transformados em marcadores do discurso voltados para a articulação e interação.

O mais relevante no trabalho desenvolvido por Risso, Silva e Urbano (2006), é que, a partir da aplicação de algumas variáveis, os marcadores apresentam a seguinte identidade básica: exterioridade em relação ao conteúdo proposicional, a independência sintática, a não-autonomia comunicativa e as funções contrabalanceadas de articulador tópico e orientador da interação, levando-se à conclusão de que os marcadores operam no plano da atividade enunciativa e não no plano do conteúdo, embora assegurem a ancoragem pragmática desse conteúdo, ou seja, codifiquem uma informação pragmática ${ }^{20}$ (porque definem a força ilocutória com que ele pode ser tomado, as atitudes assumidas em relação a ele, a checagem de atenção do ouvinte para a mensagem transmitida, a orientação que o falante imprime à natureza do elo seqüencial entre os elementos textuais). De acordo com os autores, os marcadores do discurso sinalizam articulações textuais e relações interpessoais, o que caracteriza uma função sociocomunicativa, que "aponta não só para os aspectos cognitivo-informativos contidos no produto lingüístico e nas partes de sua estrutura, mas também para a compreensão desse produto como algo que congrega e sinaliza os interlocutores, o processo de produção e interação". Monitoram localmente $o$ texto e as relações interlocutivas responsáveis por sua co-produção dinâmica e emergencial (RISSO; SILVA; URBANO, op. cit., p. 425).

Outra perspectiva importante para 0 estudo dos marcadores conversacionais refere-se às questões fonético-fonológicas envolvidas. Risso, Silva e Urbano (2006, p. 413) mostram que dos 1298 marcadores analisados, $96.7 \%$ possuem uma massa fônica de até três sílabas tônicas, contra 3,3\% que apresentam mais do que três. Isso seria um indício de que, segundo os autores, essas formas curtas sejam particularizadoras do padrão básico dos MDs (op. cit., p.414) e as mais longas ou mais desenvolvidas "tendem a ser menos modelares

\footnotetext{
${ }^{20}$ Conceito introduzido por Fraser, 1990 (apud Risso, Silva e Urbano, 2006).
} 
por se revelarem menos formulaicas e, portanto, mais sintaticamente elaboradas e portadoras de uma maior transparência semântica".

Uma questão se impõe quanto à relação prosódica que esse marcador pode manter no discurso, uma vez que poderia influenciar no fluxo conversacional e até mesmo na fluência do falante ou, pelo menos, estar diretamente a ela relacionado.

Martín-Butragueño (2006) analisa, mediante entrevistas sociolingüísticas (observando, inclusive, variação de gênero), uma série de MDs a partir das funções que eles exercem em determinados contextos - tais como estruturadores da informação, conectores, operadores argumentativos, marcadores conversacionais - e observa que há uma estreita relação entre marcador e os estilos de textos analisados (conversação, questionário lido e texto lido).

Em geral, há maior redução fônica para a conversação, sobretudo nos casos em que os falantes são homens; o linde melódico prévio é abundante em todos os estilos, mas o linde melódico final é menos geral e varia de acordo com o estilo, mas aumenta à medida que cresce a formalidade; por outro lado, boa parte dos exemplos não se servem de pausas para marcar o limite melódico posterior e parece que "a maior parte das outras linhas melódicas surgem quando o marcador não tem linde melódico posterior e se incorpora ao enunciado, recebendo então os acentos tonais que se esperariam sobre um material lingüístico situado em posição pretonemática $^{21 "}$ (MARTíN-BUTRAGUEÑO, op. cit., p. 7). Segundo o autor, "os marcadores discursivos mostram um ar de família prosódica, mas são tão maleáveis que a linha melódica segue com relativa docilidade as sutis diferenças de sentido à que se destinam"22.

\footnotetext{
${ }^{21}$ Tradução nossa do original: “(...) la mayor parte de las otras líneas melódicas surgen cuando el marcador no tiene linde melódico posterior y se incorpora al enunciado, recibiendo entonces los acentos tonales que se esperarían sobre un material lingüístico situado en posición pretonemática." (MARTÍN-BUTRAGUEÑO, 2000, p. 7)

${ }^{22}$ Tradução nossa do original: “(...) los marcadores discursivos muestran un aire de familia prosódica. Con todo, son tan maleables, en especial algunos de ellos, que la línea melódica sigue con relativa docilidad las sutiles diferencias de sentido a que se adscriben (MARTÍN-BUTRAGUEÑO, op.cit., p. 7)
} 
Esses estudos mostraram que tampouco há uma relação intrínseca entre marcadores e pausas, como antes se acreditava, fazendo com que se observem propriedades interessantes com relação à entoação. Entretanto, a sua relação com a fluência da língua materna ou estrangeira ainda merece uma atenção especial.

Nesse sentido, uma terceira perspectiva interessante para o estudo dos marcadores se encontra na sua análise dentro da interlíngua de aprendizes de língua estrangeira e, portanto, num contexto discursivo que vai além daquele de língua materna. A interlíngua desses aprendizes é sem dúvida um campo fértil para os pesquisadores, embora os estudos na área de ensino/aprendizagem de línguas estrangeiras pouco tenha se dedicado aos marcadores. Há materiais didáticos que abordam e valorizam o ensino desses elementos em sala de aula, mas ainda o fazem de forma intuitiva ou sem grande embasamento teórico-prático que justifiquem o seu ensino/aprendizagem.

Esta pesquisa pretende trazer, portanto, novos horizontes para os estudos dos marcadores conversacionais.

\section{Os marcadores conversacionais e a aquisição/aprendizagem de línguas estrangeiras.}

A relação entre marcadores conversacionais e aquisição/aprendizagem de línguas não tem sido um grande foco de pesquisa. Em geral, os pesquisadores se dedicam a processos de aquisição/aprendizagem de outras categorias da língua(gem) ou, no caso dos marcadores, aos tipos, funções e posições dos marcadores na língua materna. Alguns estudos apontam para uma relação de semelhança entre os marcadores da língua materna e os marcadores da língua estrangeira quanto à sua tipologia, funcionalidade e posicionamento, sendo que os mesmos podem ser classificados de marcadores verbais (lexicais ou não lexicais), 
não verbais (extra-lingüísticos) ou prosódicos tanto na L1 como na LE, mas estudos mais específicos ainda são raros.

Quanto à forma, geralmente aparecem formados por um léxico ou uma expressão sintática e, no caso do português e espanhol, por serem línguas originárias do latim e com grande similaridade lingüística (lexical, sintáticosemântica e fonética) alguns dos marcadores utilizados são extremamente semelhantes, tais como: bom/bueno; escuta/oye; veja/mira; não é?,/ ¿no?; não é verdade?/ ¿verdad? etc.

Para ilustrar a ocorrência dos marcadores em ambas as línguas, tomemos, como exemplo, três segmentos conversacionais, dois do português e outro do espanhol, ambos tomados de corpora de falantes cultos do idioma em que cada um se insere.

L1 ((pigarreou)) veja o que está acontecendo... por incrível que pareça há falta de doutores hoje... por quê? porque porque a tendência é acabar o curso... e muito dificilmente um vai sair para a pesquisa... para estudar para defender uma tese

L2 (defender) uma tese

L1 então nós estamos com problema inclusive... quais são os cursos de mestrado? não há doutores para... ministrar esses cursos e precisam ser... e precisam ter a categoria de doutores para poder lecionar nesses curso de pós-graduação... então é realmente um fato que está existindo... então... como está existindo essa dificuldade eu:: não tenha dúvida a especialização é super necessária ... porque depois de um de um de um estágio em 
trabalho e tudo isso você necessita aquilo você pode coadunar perfeitamente deveriam existir muitos cursos de especialização... a gente vê alguns vários até aí na nossa área por exemplo mercado de capitais existe alguns...

Segmento extraído do corpus do Projeto NURC, Inq. 062, linhas $802-819^{23}$

(2)

L1: não por enquanto não porque... estão entrando na as mais velhas estão entrando agora na adolescência e...

[

L2: $\quad($ )

L1: mas são muito acomodadas... ainda não começaram assim... aquela fase... chamada de... mais

difícil de crítica

[

L2: (chamada de mais difícil)

L1: né?

L2: ahn ahn

L1: ainda não... felizmente (ainda não) começaram

L2: ( )

L1: agora... eu acho que::... eu... espero não:: ter problema com elas porque... nós mantemos assim um diálogo bem aberto sabe?

L2: uhn uhn

L1: com as crianças... então... esperamos que não:: haja maiores problemas

L2: ahn ahn

\footnotetext{
${ }^{23}$ Inquérito presente em CASTILHO, A. e PRETI, D. (Org.) A linguagem falada culta na cidade de São Paulo. Diálogos entre dois informantes. São Paulo: T. A. Queiróz/Fapesp, 1986, p. 61-99, vol. II.
} 
L1: com o avançar dos anos... enfim... o futuro

L2:

L1: pertence...

L2: ah

L1: a Deus e não... a nós

L2: $\quad$ ( ) realmente deve ser uma delícia ter uma familia gran/bem grande com bastante gente... eu sou filha única... ah tenho um irmão de treze anos... mas gostaria deMAIS de ter tido... mais irmãos... porque quando:.... com meu irmão eu já:::já tinha curso universitário já já tinha saído da faculdade quer dizer então não tem quase que vantagem nenhuma não é? ...

Segmento extraído do corpus do Projeto NURC/SP Inq. 360, linhas $43-69^{24}$

$(3)^{25}$

A: bueno pues... yo te digo mi opinión... a nivel de que son personas para mí... que de una manera natural o bien po::r/por práctica pues son...en principio muy sicólogos... porque yo estoy rodeada por la profesión que tengo no/no:: es lo mío pero (conozco a muchas personas) ¿no?

C: yo también

A: entonces veo que tienen una gran sicología y que ellos perciben cosas

\footnotetext{
${ }^{24}$ Id. Ibiden, p. 136-178

${ }^{25}$ Neste exemplo, os signos de transcrição foram adaptados aos do Projeto NURC/SP
} 
que si tú analizas se/las puede percibir cualquiera...lo que pasa que ellos...barajan luego esto y te dicen... por una parte o sea... mm... son los rasgos mismos de la persona... físicos la manera de act/lo que tú pensarías o sea/...sicología

B: $\mathrm{mm}$

A: el como actúa esta persona si es más impulsiva menos luego ver... o sea si te está contando que se va de viaje que hace un crucero pues... problemas económicos no tienen... o sea has de estar atento a todo lo que<smiles>[TlH]</smiles>

B: claro por eso te digo que

[

A: se dice

C: de todas formas... yo conozco uno que es alucinante eh?

A: por eso te digo

C: yo conozco uno que ES increíble/ a mí

A: yo te digo

C: me deja cada vez que le digo una cosa le consulto algo a mí es que me deja... mira yo me acuerdo... no sé si os acordaréis que en abril unos ami/Sí... los hijos de Fermín y Concha

?: $\mathrm{mm}$

C: ¿te acuerdas...que tuvieron un accidente? ¿tú no lo has sabido? Segmento extraído do corpus do Projeto Val.Es.Co. [MT.97.A1] $)^{26}$

\footnotetext{
${ }^{26}$ Conversação presente em BRIZ-GÓMEZ, A., GRUPO VAL.ES.CO. Oralia. Corpus de Conversaciones coloquiales. Madrid: Arco/Libros, 2002, p. 351-368.
} 
A seguir, apresentamos duas listas de marcadores das duas línguas que puderam ser observados. Nos exemplos dados os marcadores em português e em espanhol são muito similares no tocante a sua estrutura léxico-frasal, ou seja aparecem em sua forma simples (uma única palavra) ou em sua forma composta, formando frases.

\begin{tabular}{|l|l|}
\hline $\begin{array}{l}\text { Lista com os marcadores mais relevantes } \\
\text { presentes nos exemplos (1) + (2) }\end{array}$ & Correspondência em espanhol \\
\hline veja o que está acontecendo & lo que sucede es \\
\hline por incrível que pareça & lo increíble es que \\
\hline porque & porque \\
\hline então & entonces \\
\hline então inclusive & incluso \\
\hline realmente & realmente \\
\hline não tenha dúvida & no hay duda \\
\hline até aí & hasta entonces \\
\hline por exemplo & por ejemplo \\
\hline mas & pero \\
\hline assim & así \\
\hline né? & ¿no? \\
\hline ahn ahn & mm mm \\
\hline ainda não & no todavía \\
\hline agora & ahora \\
\hline eu acho que & creo que \\
\hline eu espero não & espero que \\
\hline sabe? & ¿sabes? \\
\hline uhm uhm & uhm uhm \\
\hline enfim & en fin \\
\hline ah & ah \\
\hline quer dizer & o sea \\
\hline não é? $?$ ¿no? \\
\hline por enquanto não no \\
\hline
\end{tabular}




\begin{tabular}{|c|c|}
\hline $\begin{array}{l}\text { Lista com os marcadores mais relevantes } \\
\text { presentes no exemplo (3) }\end{array}$ & Correspondência em português \\
\hline bueno pues & bom então \\
\hline y te digo mi opinión & e te digo minha opinião \\
\hline o bien por & ou bem por \\
\hline pues & pois \\
\hline porque & porque \\
\hline pero & mas \\
\hline ¿no? & não é? \\
\hline yo también & eu também \\
\hline entonces & então \\
\hline veo que & vejo que \\
\hline lo que pasa & o que acontece \\
\hline luego esto & justo isto \\
\hline por una parte & por uma parte \\
\hline o sea & ou seja \\
\hline $\mathrm{mm}$ & uhm uhm \\
\hline lo que tu pensarías & o que você pensaria \\
\hline luego ver & vamos ver \\
\hline has de estar atento a todo lo que & tem que estar atento a tudo \\
\hline claro & claro \\
\hline por eso te digo que & por isso te digo \\
\hline ¿eh? & e/é \\
\hline yo te digo & te digo \\
\hline mira & veja \\
\hline yo me acuerdo & eu me lembro \\
\hline no sé & não sei \\
\hline ¿te acuerdas? & se lembra? \\
\hline es increíble & é incrível \\
\hline
\end{tabular}

Observamos que praticamente reconhecemos todos os marcadores na lista dos mais relevantes em espanhol. Talvez com exceção do marcador lexical "luego ver" e da diferença idiomática para representar os marcadores não lexicais 
("mm", "eh") todos os demais apresentam uma correspondência em língua portuguesa.

A grande maioria apresenta uma função comunicativa e poucos são os que apresentam uma função sintática, como nos exemplos:

A: Função comunicativa:

(1) então nós estamos com problema inclusive... quais são os cursos de mestrado? não há doutores para... ministrar esses cursos e precisam ser... e precisam ter a categoria de doutores para poder lecionar nesses cursos de pós-graduação... então é realmente um fato que está existindo... então... como está existindo essa dificuldade

(2) L1: com as crianças... então... esperamos que não:: haja maiores problemas

L2: ahn ahn

L1: com o avançar dos anos... enfim... o futuro

(3) entonces veo que tienen una gran sicología y que ellos perciben cosas que si tú analizas se/las puede percibir cualquiera...lo que pasa que ellos...barajan luego esto y te dicen... por una parte o sea... mm... son los rasgos mismos de la persona... físicos la manera de act/lo que tú pensarías o sea/...sicología

Nos exemplos anteriores, "então", "inclusive", "realmente", "enfim", "entonces", "luego esto", "lo que pasa", "luego esto", "por una parte”, "o sea”, "lo 
que tú pensarías" funcionam basicamente como marcadores comunicativos, podendo ser eliminados completamente dos diálogos em que se inserem sem qualquer prejuízo de sentido, entretanto, participam da interação e coesão do texto falado.

B: Função sintática:

(1) a especialização é super necessária... porque depois de um de um de um estágio em trabalho

(2) tenho um irmão de treze anos... mas gostaria deMAIS de ter tido... mais irmãos... porque quando:....

(3) porque yo estoy rodeada por la profesión que tengo

Nesses exemplos, os marcadores "porque" e "mas" não poderiam ser excluídos como no caso anterior, posto que haveria prejuízo de sentido. Por isso, exercem no contexto em que se inserem uma função basicamente sintática. Seriam os chamados operadores conversacionais.

Quanto à posição que ocupam nos enunciados, aparecem no início, final ou meio de uma intervenção, sendo que em posição mediana ajudam no desenvolvimento e avanço do tópico discursivo. Em posição de início, além de tomar o turno, auxiliam na sua manutenção e, no final, entregam o turno ou facilitam na tomada de turno pelo interlocutor. Em resumo, quanto à posição não há diferenças entre os marcadores.

Os marcadores verbais não-lexicais ("uhm uhm", "ahm", "ah", "eh") estão presentes - em alguns casos, preenchendo pausas -, bem como os prosódicos (pausas, alongamentos). Mais uma vez, os recursos utilizados pelos falantes dos dois idiomas coincidem. 
A comparação realizada oferece uma pequena mostra da semelhança no uso de marcadores entre as duas línguas. Parece corroborar, portanto, a afirmação feita por muitos pesquisadores de que os marcadores conversacionais são universais.

Não temos dados suficientes para afirmar como se processa a aquisição desses elementos durante o processo de aquisição/aprendizagem de língua materna ou estrangeira. No entanto, de acordo com Kuhl (2000), os ouvintes necessitam de uma experiência correta de audição, em que se inclui também a exposição à língua materna para que esta possa ser adquirida. O mesmo efeito se observa no caso de aquisição/aprendizagem de línguas estrangeiras. Há um consenso de que o aluno deve estar exposto o maior tempo possível à língua que está aprendendo e faz-se necessário que essa exposição tenha qualidade. Entretanto, outros fatores intervêm nesse processo, como, por exemplo, os psicológicos que envolvem a motivação e a autoconfiança.

A questão prosódica, nos moldes relatados por Kuhl e por Scarpa (1999), também são aplicados à língua estrangeira. Quanto maior o input maior é a percepção prosódica e, se associado a frases estereotipadas (como no caso das frases motherese, como, por exemplo: (1) Onde está o cachorrinho?; (2) Veja o au-au... (3) Isto é um bichinho!; cuja entoação e ritmo são enfatizados, melhores são os resultados. Tomemos outro exemplo: os marcadores conversacionais. Nesse caso, a freqüência de seu uso e os princípios pragmáticos de negociação, proteção da face negativa e necessidade de interação parecem favorecer a sua aprendizagem e fixação no outro idioma. Por outro lado, o marcador também parece facilitar a aquisição/aprendizagem da prosódia da língua estrangeira e, em alguns casos, a fixar alguns elementos da sua fonética. Por exemplo, o marcador em espanhol vale, quando utilizado repetidas vezes pelo professor, auxilia na memorização do som da letra $v$, ao mesmo tempo em que, por aparecer tanto em frases interrogativas como asseverativas, conduz 0 aluno à reprodução entoacional e fonética correta para cada caso (GONÇALVES, 2000). 
É certo que nos valemos de um exemplo muito simples, mas, empiricamente, o mesmo resultado repetiu-se em experiências posteriores com outros marcadores. De início os alunos tentam imitar o professor, logo, começam a reproduzir corretamente a pronúncia das palavras em que o fonema presente no marcador aparece e, mais tarde, a entoação. Às vezes, os marcadores antecedem estruturas específicas da língua e, nesse caso, orientam a gramática da língua, fixando modelos que comporão o repertório frasal da língua alvo. Um bom exemplo disso é o caso dos marcadores argumentativos, sobretudo aqueles que compõem uma estrutura frasal. Quando o aluno, em um contexto de ensinoaprendizagem, assimila o marcador "yo creo que...", além de compreender o seu uso semântico e discurso para a construção de uma argumentação, fixa a sintaxe correspondente, ou seja, após a afirmação sabe que deverá usar um verbo no presente; na situação inversa, quando utiliza o marcador argumentativo negativo "no creo que..." sabe que deverá usar o subjuntivo. Dessa forma, parece que a fonética, sintaxe e semântica são inseparáveis e se inter-relacionam intrinsecamente na construção de um sentido discursivo.

Acreditamos, assim, que a percepção e produção são interdependentes e que devem seguir juntas durante todo o processo de aprendizagem e uso da língua estrangeira, ou seja, devem fazer parte da "atitude" do aprendiz/usuário da língua estrangeira, de tal sorte que venham compor uma espécie de continuum comportamental para que se logre a eficiência na produção oral em outro idioma.

Corroboramos, portanto, a afirmação de Scarpa (1999) para quem o reconhecimento do fato de que a criança tem acesso à hierarquia prosódica desde o começo da aprendizagem traz mais força para argumentos em prol de variabilidade inter e intrafalantes. Na fala inicial, a ponte entre som e significado começa a ser traçada pela prosódia, o que guiará a criança em direção aos limites de uma possível gramática. No caso do adulto, aprendiz de uma língua estrangeira, o reconhecimento prosódico deve ser o primeiro passo para o reconhecimento das estruturas gramaticais, inclusive porque desse reconhecimento depende a compreensão do sentido real do que se diz. 
Do nosso ponto de vista, a criança que aprende uma língua materna ou o aprendiz de uma língua estrangeira "testam" as possibilidades prosódicas e fonéticas da língua e no momento em que uma combinação ocorre corretamente, ou seja, encontra uma reação positiva do adulto/ interlocutor, percebida através dos sinais manifestados por este, ela a fixa na memória e tentará repeti-la posteriormente, testando também os contextos situacionais. Há, acreditamos, um processo contínuo de "tentativas" que conta com a interação do outro, como também aponta Lemos (2003). Por exemplo, em espanhol a "ditongação" encontro de duas vogais em determinadas palavras, como puedo/vuelvo - é bastante freqüente, no entanto, o aluno a utiliza sempre que quer "falar bem" a língua, cometendo equívocos por vezes muito graves, como dizer cueca cuela, fuerma (em lugar de coca-cola, forma). Na verdade, o aluno testa uma determinada forma fonética e prosódica, e aguarda a resposta do outro (muitas vezes, o professor). Se o professor adverte sobre o erro, ele tenderá a corrigi-lo e memorizar a forma correta, caso essa correção não se realize, a tendência é de que ele memorize e repita o erro.

Dessa forma, acreditamos que a correção é fundamental no ensino de uma língua, além do que os modelos devem ser bons, como propõe Kuhl (2000), para que haja uma boa produção.

A prosódia é também uma possível resposta para o fato de falantes bilíngües efetuarem trocas de códigos. Vejamos os dois exemplos de enunciados reais de falantes bilíngües do português (língua materna) e espanhol (língua estrangeira):

(1) "Deixei minha carpeta sobre a mesa."

(2) "A aula começa às dez, o sea, temos que sair às nove de casa." 
Nos dois exemplos, a palavra "carpeta" e o marcador "o sea" podem ser meramente transferências da segunda língua para a língua materna, cujo uso poderia estar vinculado à freqüência com que o falante utiliza tais palavras no seu dia a dia. Entretanto, dependendo de quem seja o seu interlocutor, as frases poderão ser construídas de outra maneira, por exemplo, se o interlocutor for um falante do espanhol (nativo ou não,) mas cuja característica é de conhecimento do falante:

(1) "Deixei minha carpeta sobre la mesa"

(2) "A aula começa às dez, o sea, tenemos que salir a las nueve."

Nesse caso, deixarão de ser transferências para constituírem elementos fundamentais na troca do código lingüístico. Isso ocorrerá, provavelmente, pelo reconhecimento fonético ou prosódico que se realiza ao se pronunciar algumas palavras que funcionam como verdadeiros gatilhos desencadeadores da mudança de um idioma a outro.

Uma situação semelhante parece ocorrer na interlíngua de aprendizes de espanhol.

Como já comentamos anteriormente, o termo interlíngua foi utilizado pela primeira vez por Selinker (1972) que a definiu como sendo o sistema lingüístico que resulta das tentativas do aprendiz de produção de uma norma da língua objeto.

A partir de uma perspectiva psicológica, Selinker parte do princípio de que se um adulto consegue na L2 a competência de um falante nativo é devido ao fato de ter reativado, de alguma forma, a estrutura latente da linguagem, descrita por Lenneberg, em 1967 (Cf. Selinker, 1972, p. 82). 
Selinker aponta que somente uns $5 \%$ dos aprendizes conseguirão a competência de um falante nativo. Isso pressupõe que apenas uma minoria será capaz de utilizar uma série de estratégias psicolingüísticas que o levará a ativar a estrutura latente da linguagem. Dentre elas, o autor sugere cinco principais processos psicolingüísticos que estabelecem o conhecimento que está por trás da produção da interlíngua, a saber: transferência lingüística, transferência de instrução, estratégias de aprendizagem da segunda língua, estratégias de comunicação na segunda língua e a hipergeneralização do material lingüístico da língua objeto (op. cit., p. 82-83).

É nesse último caso que se inserem um dos "erros" mais comuns na aprendizagem do espanhol: a ditongação exagerada, formar palavras com ditongos quando não existem, como o exemplo da "cueca cuela" mencionado anteriormente.

Se, por um lado, alcançar a competência de falante nativo é quase impossível, ou privilégio de poucos, por outro lado, compreender os mecanismos de aquisição/aprendizagem de línguas pode auxiliar na tentativa de que os resultados sejam pelo menos bem satisfatórios.

Por isso, as pesquisas na área são importantes e podem contribuir para a criação e desenvolvimento de estratégias de ensino que, cada vez mais embasadas nos conhecimentos teóricos, auxiliem tanto alunos como professores a alcançar seus objetivos.

\section{O marcador então / entonces: um breve estudo analítico}

Quando observamos empiricamente a produção oral de aprendizes de espanhol no Brasil, o uso do marcador entonces chama a atenção por parecer ter um uso constante e, às vezes, exagerado na fala dos alunos. Na tentativa de 
compreender um pouco mais a sua presença e a sua relação na interlíngua dos aprendizes, extraímos alguns segmentos de conversação e procedemos a uma análise de sua função, comparando essa situação com estudos desenvolvidos por pesquisadores de língua portuguesa e de língua espanhola, posto que é, também, um dos marcadores mais analisados por esses estudiosos nos dois idiomas.

A análise que se segue foi realizada a partir de alguns segmentos extraídos de quatro diálogos realizados com jovens estudantes de um curso de Letras, de nível intermediário de aprendizagem do espanhol.

Se observamos as ocorrências em cada diálogo, encontraremos os seguintes exemplos:

Exemplo I:

(1)

B: piensas entonces que es mejor que la pareja se separe

(2)

A: un ser humano es lleno de equivocaciones entonces puede equivocarse (al pasarlo) las parejas las parejas no tienen que ser perfectas y esa búsqueda de la perfección (...)

(3)

A: es eso que los hombres piensan algunos llevan eso yo puedo traicionar pero tú no porque tú eres mía estás en mi mano y yo tengo el poder (bajo tú) ¿no es? ((risas)) entonces hay primero que mantener un pensamiento que eh la pareja sí ambos tienen que llevar la misma convicción yo te respecto tú vas a respectar a mí también (...) 
Exemplo II:

(1)

A: (...) y si no estamos felices entonces el amor se acaba el casamiento es la es la base del casamiento es el amor (...)

(2)

B: $\quad(. .$.$) porque es una es como un un dictado eh no haga cosas eh que$ no gustarías no gustarías que hicieran contigo entonces no haga con nosotros entonces eso de estar saliendo con con el otro con una la otra persona para mí no es muy positivo es algo muy negativo

(3)

B: (...) pienso que la felicidad siempre estamos a buscar y que cuando no no vemos que no está bien entonces tivemos ten tendramos que buscar una otra manera para que seamos felices entonces es mejor para mí entonces que esta persona se divorcie y viva el amor que que he encontrado no sé pero esa cosa de estar con dos personas totalmente (ligadas) no es bueno (...)

Exemplo III:

(1)

A: caso porque como tú habla habló pienso que a ella hace falta algo entonces veo por su su lado también y me quedé (per) los dos

(2)

A: ella entonces no debía se quedar muy apasionada por él porque se él la quiere también tiene que querer el hijo 
Exemplo IV:

(1)

A: (...) entonces va a así la música vas diciendo muchas cosas que la otra persona hace y que lleva la primera persona a tener esta actitud entonces creo porque por lo menos las personas son muy así esto puedo esto no puede pero hay tantas cosas que ocurren en la vida de una persona tantas cosas que llevan una persona a (estas actitudes) no creo que es una cosa errada

(2)

A: (...) tengo en mi vida que tenemos que ser verdaderos tenemos que ser correctos ahm principalmente porque hay otra persona ahm porque estamos viviendo con otra persona entonces ten eh tenemos que ser correctos entonces ahm si ella está un poco triste un poco perdida un poco sí triste ahm pienso que tenía que que hablar con su marido que ahm hablar todo lo que está sentiendo porque no pienso que es correcto

(3)

A: porque estás haciendo una cosa que que no podrías hacer pero las la vida lle eh vas ocurriendo de una forma que las personas no encuentran saida

B: é não da

A: entonces no es que creo que es correcto

(4)
A: difícil muy difícil porque eh
B: como ella como tiene un hijo el hijo jamás entenderá entonces 
Nos exemplos mencionados, podemos observar que entonces, normalmente classificado como um dêitico temporal, não assume essa função em nenhum dos diálogos. Outrossim, facilmente podemos substituí-lo por conjunções do tipo conclusivas (ex.: portanto) ou ainda por advérbios (ex.: conseqüentemente).

Vejamos alguns exemplos de uso de entonces por falantes do espanhol peninsular (ROMERA, 2003, p. 4):

(1) Es como si yo entonces hubiera abierto ante mí un pozo.

(2) Nació en 1965. Entonces, controlaban España los tecnócratas.

(3) Pedro me dijo que entonces iba a estudiar.

(4) Pedro me diria que iba a estudiar entonces.

(5) Pedro dijo que iba a estudiar entonces.

(6) Y luego separas las yemas de las claras, entonces en un bol bates las claras a punto de nieve.

A princípio, no exemplo (1) a autora classifica entonces como um dêitico temporal, por sua referência a um passado ou futuro e por se opor ao significado de ahora, que faz referência ao presente. Poder-se-ia substituir entonces por en aquel momento. Por sua vez, no exemplo (2) ainda que se possa substituí-lo por en aquel momento / en aquella época, observa-se que ele se refere a 1965 e, nesse sentido, seria uma repetição do ano mencionado anteriormente. Daí a autora considerá-lo como um elemento anafórico, embora ainda fixe uma marca temporal.

Porém, nem sempre é tão fácil distinguir suas funções e, quando observados dentro de contextos interativos, diz a autora, entonces "não co-varia com os parâmetros básicos do evento de fala (tempo, espaço, participantes) como faria um dêitico simbólico, senão que sua referência varia e se reajusta em cada ocasião de acordo com a informação introduzida lingüisticamente no discurso, ou 
seja, sempre necessita de uma informação lingüisticamente atualizada para ser interpretado." (ROMERA, op. cit., p. 5)

Assim, em (3) e (4), comenta a autora, entonces representa um elemento temporal ligado aos morfemas de tempo de dijo/ diria, que atuam como seus antecedentes.

Em (5), entonces nos faz situar o tempo do Evento $_{a}\left(E_{a}\right)$ no tempo do Evento $_{b}\left(E_{b}\right)$

E a Pedro dijo

$E_{b} \quad$ que iba a estudiar entonces

Romera (op. cit., p. 6) acrescenta que, na ausência de entonces (Pedro dijo que iba a estudiar) o $E_{a}$ e o $E_{b}$ continuam unidos pelos seus respectivos morfemas temporais, mas não há referência sobre quando irá acontecer $0 E_{b}$. A única informação transmitida é que $o E_{b}$ se situa depois do $E_{a}$ graças à correlação temporal concreta que se estabelece mediante os morfemas de tempo do pretérito perfeito e pretérito imperfeito.

Para o exemplo (6), Romera (op. cit., p. 7) comenta que tradicionalmente os gramáticos iriam classificá-lo como elemento anafórico, por estar ligado a um antecedente, entretanto, apresenta as mesmas características atribuídas ao dêitico do exemplo (3). Aponta a um tempo não coincidente com o tempo de fala; pode ser substituído por en ese momento e sua referência temporal concreta não pode ser entendida a menos que se relacione com um evento prévio anteriormente mencionado no discurso e, por fim, expressa uma relação temporal entre o evento em que está incluído e seu evento antecedente. Dessa forma, comenta a autora, a maior diferença entre (3) e (6) não parece estar na natureza anafórica ou dêitica de entonces, mas no tipo de relação estabelecida entre a unidade de entonces e a unidade que contém seu antecedente. Em (6) a oração 
introduzida por entonces se encontra em relação paratática ou coordenada com a oração em que está localizado seu antecedente (estão no mesmo nível de relevância), em (3) a oração em que aparece entonces está em relação hipotática ou subordinada com relação à oração de seu antecedente (HALLIDAY; HASAN 1976, MARTíN, 1992, apud ROMERA, 2003, p. 7). Além disso, em (6) entonces conecta as orações e, portanto, além de expressar o tempo referencial de "bater as claras", também pode ser considerado como a conexão entre as duas emissões. Já em (3), entonces não pode ser um conector, posto que já há um conector de tipo subordinado (que) e se mantém somente como a expressão do tempo referencial de "ele ia estudar".

Romera (op. cit., p. 8) ressalta que tanto em (3) como em (6) não há uma diferença semântica real entre entonces como advérbio demonstrativo e entonces como conector. O que encontramos, nos dois exemplos, é o advérbio demonstrativo que ocupa posições distintas. "É precisamente a natureza anafórica permanente do advérbio temporal o que permite que entonces relacione eventos em ambos casos." Conclui destacando que, em espanhol, pelos exemplos estudados, entonces sempre apresenta um componente anafórico do qual não pode prescindir para resolver seu referente e que os supostos usos dêiticos de entonces compartilham as mesmas características semânticas que os usos anafóricos.

Se comparamos os exemplos da interlíngua dos informantes desta pesquisa com os exemplos de nativos do espanhol peninsular citados por Romera, veremos que entonces não apresenta propriamente o caráter de anáfora temporal empregado pelos usuários naturais da língua. Na maioria dos casos, entonces assume características de conjunções conclusivas ou até mesmo advérbios, conforme comentamos anteriormente.

Tendo em vista uma análise pragmática do uso do marcador entonces, BrizGómez e Hidalgo (1988, p. 132) apontam para o caráter argumentativo desse marcador, bem como para a sua função metadiscursiva quando atua como 
continuador e marca de progressão no interior do enunciado, ou como recuperador do fio comunicativo, depois de algum enunciado parentético ou explicativo, ou ainda como uma marca conversacional de recuperação de turno ou de persistência discursiva (dependendo da posição em que aparece - inicial ou medial). Vejamos os exemplos que nos dá:

1.Como continuador e marca de progressão:

A: no algunas chicas es que son muy morenas entonces son así son como yo blancas ellas negras entonces es están muy morenas

2. Como recuperador do fio comunicativo:

L: y luego fuimos a la discoteca y en un momento que el Chico desapareció porque fue al cuarto de baño ya no volvia o sea había desaparecido entonces empezamos a buscarlo entonces María descubrió.

3. Como marca conversacional de recuperação:

C: teléfono no tenemos todos no tenemos los que tenemos ventana porque recogemos nosotros la señal
B:
la señal

C: y entonces ellos la reciben a través del del teléfono

Comparativamente, o marcador então, do português, quando analisado sob a perspectiva da análise da conversação e, conseqüentemente, das funções que 
exerce nos processos de interação, também serve para articular as relações entre os interlocutores e sustentar a interação.

Andrade (1990, p. 230) salienta que marcadores como então exercem funções estruturadoras e interacionais. Em suas funções estruturadoras, eles podem articular o texto ou segmentá-lo, isto quer dizer que desempenham funções textuais e argumentativas, pois "asseguram a continuidade do discurso e hierarquizam argumentos e/ou enunciados, na medida em que são capazes de indicar o tipo de articulação que estabelecem (explicação, conseqüência, conclusão, etc.)". Por outro lado, não perdem a carga semântica de origem adverbial, comenta a autora (op. cit., p. 238).

Em suas funções interacionais, "comandam estratégias empregadas pelos interlocutores na construção e manifestação de identidades sociais" e essas funções são "observadas em esquemas lingüísticos, com a finalidade de conduzir a interação de forma que não haja riscos para as faces dos interlocutores, revelando o seu envolvimento na atividade conversacional”. (ANDRADE, 1990, p. 230).

Em suma, para Andrade o marcador então exerce papéis tanto conversacionais como sintáticos na progressão textual. Como articuladores ou segmentadores do texto, indicadores de conclusão, conseqüência, explicação ou justificativa, seqüência e avaliação ou introdutores de paráfrase, então "promove a condução e a manutenção do tópico discursivo, instaurando a solidariedade conversacional entre os interlocutores, na medida em que propiciam dinamismo e continuidade à interação." (op. cit., p. 239-242).

Corrobora essa análise o trabalho de Risso (1996, p. 423), no qual o marcador então aparece no processamento de aberturas, encaminhamentos, retomadas e fechos de tópicos discursivos, mais concretamente atuando no estabelecimento das relações coesivas e como sinalizadores diretos da interação. Por apresentar uma função primordial no processamento da informação e na 
tessitura dos tópicos que se lhe associam, a autora o classifica como um marcador tipicamente articulador de partes do texto.

Do ponto de vista da coesão frasal, então não necessariamente se prende à noção de passado; freqüentemente assume um teor mais argumentativo, "ao servir à expressão de uma dependência lógico-semântica de decorrência, conclusão ou resultado, assentada na relação de implicatividade entre fatos ou argumentos, dentro da proposição". (RISSO, 1996, p. 426). A autora ainda acrescenta o papel de ponto de apoio pela reiteração de uma circunstância temporal anteriormente expressa, bem como uma dúplice relação seqüencial que envolve simultaneamente a expressão de tempo e de ações motivadas entre si. Aponta, também, para a relação de causa e efeito que pode apresentar em determinados enunciados, bem como uma correlação com a conjunção "se", reforçando, assim, o nexo pelo qual o conteúdo de uma cláusula antecedente implica uma espécie de dedução expressa na conseqüente. Por vezes, também apresenta a idéia de contraste entre duas opções que são expostas na frase, acentuando a idéia de exclusão de uma delas.

Vejamos alguns exemplos dados pela pesquisadora e contidos nos diálogos do projeto NURC/SP:

(1) quando sai... aquela folia assim de um correr atrás dela então ela se cala um pouco

(D2 SP 360,1. 236-237)

Aqui, então apresenta um caráter anafórico. Representa, pois, um ponto de apoio pela reiteração de uma circunstância temporal anteriormente expressa.

(2) se a mãe buZIna... mais brabamente então é porque está atrasado.

(D2 POA 291 1, 107-109) 
Assim, como tendências básicas para o uso do então em português, dentro dessa perspectiva, a autora assinala:

1) diluição de significação temporal presa a um passado previamente mencionado no discurso;

2) progressiva propensão para o desempenho de uma função conectiva, mediadora de relações entre segmentos oracionais;

3) vocação para suceder e escopar estruturas de manifestação temporal bastante diversificadas, aliada à sua atuação constante no sentido de fazê-las repercutir no espaço discursivo;

4) incorporação de um valor resultativo-conseqüencial-conclusivo seqüenciando orações; concomitantemente ou não com a sinalização de uma temporalidade entre elas;

5) constante ancoragem em instância preliminar do discurso, para daí depreender o rumo da sucessão dos eventos dados mais à frente (cunho anafórico).

Sob a ótica de uma coesão textual-interativa, Risso (1996, p. 440) analisa o marcador então como o responsável pelas funções de:

a) projetar a continuidade da explanação que vinha sendo desenvolvida;

b) veicular o retorno à explanação anteriormente suspensa; 
c) encaminhar, em co-ocorrência com o conectivo ou, para a formulação de uma segunda alternativa exemplificadora, numa expansão do detalhamento de situações ilustrativas antes desencadeado.

Além da relação agregadora estabelecida pelo marcador, então também assume uma nítida confluência entre a estrutura ideacional e a interpessoal do discurso. Risso comenta (1996, p. 440) sobre a presença do marcador em relações de disputa de turno (assalto ou tentativa de manutenção de turno), em que, freqüentemente, encontra-se sobreposição de vozes; ou em situações relacionadas a alguma discordância de pontos de vista, em que se pode analisá-lo como operador argumentativo ocorrente após uma seqüência de atos de fala. Também podemos encontrá-lo como articulador textual mediando uma interação típica de uma "polarização negativa" ${ }^{27}$, em que há dissenso entre os interlocutores e reação à forma como um deles opina sobre o tema - "trata-se de um emprego de forte peso pragmático-interacional, entretanto apoiado na relação ideacional de implicatividade, traduzida amiúde pelo referido item anafórico." (RISSO, op. cit., p.444). Em síntese, para a autora "as funções do marcador então passam pela simples junção seqüencial de tópicos ou de porções tópicas, num encadeamento informacional linear de pouca densidade argumentativa, até a conexão assimétrica de partes interrelacionadas por ações de dependência conclusivo-conseqüencial de alcance argumentativo variado, conforme o contexto comunicativo de sua ocorrência." (RISSO, op. cit., p. 445)

Podemos afirmar que o aluno brasileiro, no seu anseio de garantir a comunicabilidade no idioma estrangeiro, utiliza os marcadores como instrumento de interação e produção oral. Dessa forma, os marcadores apontados nesta pesquisa desempenham a verdadeira função de um marcador conversacional, como elementos inter-relacionadores de enunciados, turnos e/ou tópicos, quer seja conduzir e orientar as atividades do locutor e do interlocutor, funcionando como conector interativo (ANDRADE,1990, p. 101). Os marcadores não

\footnotetext{
${ }^{27}$ Denominação dada por Castilho, 1989 (apud RISSO, 1996, p. 444)
} 
contribuem com acréscimos informacionais para o conteúdo da unidade comunicativa, diz Marcuschi (1986, p. 10), mas exercem funções interacionais que comandam estratégias adotadas pelos interlocutores na construção e manifestação de suas identidades sociais. Buscam, assim, construir um evento comunicativo em que a cooperação está implícita, pois ela é necessária para que o evento se constitua de fato (ANDRADE, 1990, p. 104).

Talvez, caiba, portanto, ao professor de espanhol, orientar adequadamente seu aluno e dar-Ihe outros elementos (marcadores) que possam adequar-se a cada situação comunicativa, trabalhando, assim, a fluência e a correção no idioma alvo e garantindo a aprendizagem da língua estrangeira o mais próximo possível do que seria a fala de um nativo.

Esta breve análise foi realizada a título de ilustração sobre o uso e função de marcadores em contextos de interlíngua. Tudo leva a crer que o processo de aquisição/aprendizagem de línguas dos marcadores corresponde também aos princípios interacionais e socioculturais que se estabelecem em todos os níveis de aquisição de linguagem e estão diretamente relacionados com a necessidade do ser humano de manter relações sociais fundamentadas em princípios de cooperação que fazem com que ao longo da história das línguas - incluídos aí os processos de aquisição/aprendizagem, transformações sociais, culturais e ideológicas - alguns elementos sofram uma descategorização natural em prol do êxito conversacional. 
CAPÍTULO V 


\section{OS MARCADORES CONVERSACIONAIS NA INTERLÍNGUA DOS APRENDIZES DE LÍNGUA ESTRANGEIRA}

\section{Para uma análise dos marcadores conversacionais}

Dado que o corpus é constituído por uma coletânea de oito textos orais, cada um de uma dupla de falantes, a sua representação está feita tanto através da transcrição do seu conteúdo para texto escrito, quanto pela disposição, em planilhas, dos marcadores encontrados.

A vantagem de se fazer uma representação fundamentada em freqüências é a possibilidade de se investigar propriedades da composição do texto oral quer sejam qualitativas ou quantitativas.

Dentre as propriedades que podem ser investigadas estão a dinâmica com que se realiza o repertório de marcadores de cada um dos falantes, a influência trocada entre os repertórios individuais e o comportamento da distribuição dos marcadores frente ao tópico discursivo.

O repertório de marcadores conversacionais realizados num texto oral é o conjunto finito de exemplares de marcadores nele encontrados e constitui o indicador de riqueza das escolhas.

No decorrer da elaboração do texto oral, o conjunto acima citado vai sendo incrementado de novos elementos, de tal forma que, concluído o texto, teremos um conjunto finito de elementos que representará toda a variabilidade de escolhas realizadas. 
Entretanto, pode-se notar que a taxa de incremento do conjunto repertório não é constante, sendo maior a princípio da conversação e decaindo, durante o transcorrer do texto oral.

Desta forma, consideramos que a dinâmica de realização do repertório de marcadores pode ser representada pela acumulação de cada exemplar de marcador por linha de transcrição, o que equivale, aproximadamente, a cada intervalo médio de tempo referente à quantidade de linhas consideradas.

O estudo da dinâmica de realização de marcadores, tal qual definimos aqui, corresponde à verificação das freqüências acumuladas e à listagem dos marcadores cujas freqüências não forem nulas para um determinado instante da conversação. Trata-se, portanto, de uma listagem em função do tempo, capaz de mostrar, por exemplo, o momento em que mais do que $50 \%$ dos elementos do conjunto final já participaram do processo da enunciação.

Abaixo segue, por exemplo, um histograma tirado a partir da variação do repertório em função do número de linhas da Planilha $5 \mathrm{~A}^{28}$, referente à Freqüência Acumulada.

\footnotetext{
${ }^{28} \mathrm{O}$ eixo horizontal refere-se ao desenvolvimento da conversação por linhas e o eixo vertical ao número de elementos do conjunto repertório, constituído pelos exemplares dos marcadores encontrados, ou seja, as repetições são consideradas apenas uma vez. Note-se que o número de linhas é diretamente proporcional ao intervalo de tempo decorrido da conversação.
} 


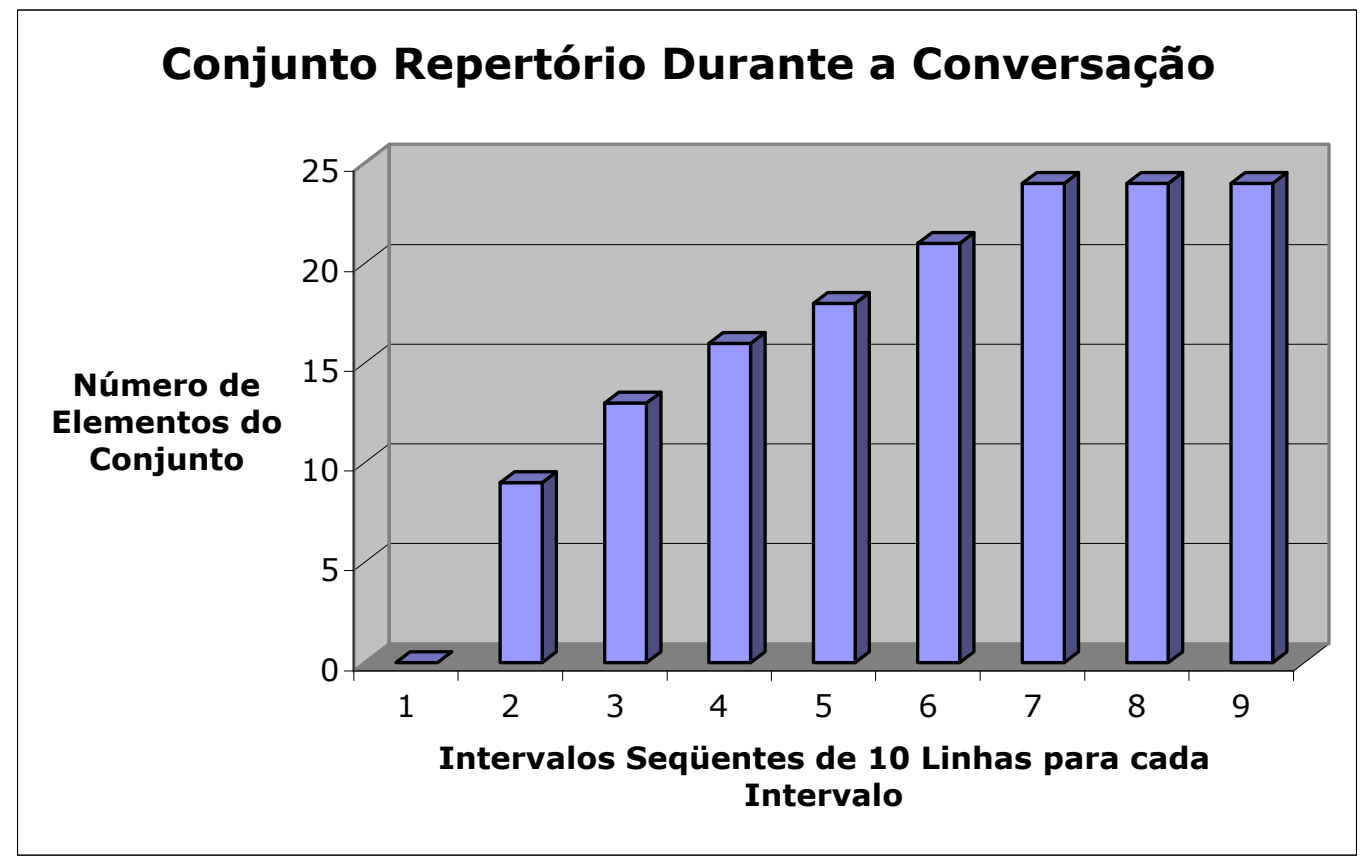

É possível perceber, através do histograma que, para o texto da Planilha $5 \mathrm{~A}$, o momento em que $50 \%$ do repertório já estava acumulado está entre as linhas 20 e 30, o que equivale a dizer entre os instantes 1,5 min e 2,2 min, aproximadamente.

A partir do procedimento acima, interessa, também, saber quais marcadores são comuns aos textos produzidos por todos os falantes e o significado desse subconjunto diante do conjunto repertório final.

Para que se possa obter uma resposta para a investigação acima é necessário separar em canais distintos os falantes, fazendo para cada um uma descrição minuciosa dos marcadores empregados.

Através da separação dos textos de cada falante, é possível conferir se existe, durante a conversação, um ajuste entre os repertórios individuais; ainda mais, a influência do repertório já realizado no texto oral sobre aquele que se vai realizar. Este último pode ser deduzido pelo índice de compartilhamentos do emprego de cada um dos marcadores, ou seja, quantos marcadores foram 
empregados pelos dois falantes frente ao total de elementos do repertório.

O desenvolvimento da composição textual, observado a partir do conjunto repertório em função de um parâmetro que indique a sua progressão (número de linhas ou tempo), é o fenômeno que permite uma análise qualitativa sobre os dados quantitativos.

Para observar o desenvolvimento da composição do texto oral dos falantes foram criadas planilhas em Excel capazes de separar os falantes em canais distintos.

Esta separação tem, como base de dados, a ocorrência discriminada, linha a linha, de cada tipo de marcador.

As planilhas de inserção de ocorrências possuem os marcadores em suas linhas e a referência às linhas do texto transcrito em suas colunas. Essas colunas da planilha estão divididas, para dar facilidade de observação, em grupos de 40 linhas do texto transcrito, com um totalizador na última coluna.

Abaixo, vê-se parte da Planilha $5 A^{29}$ :

\footnotetext{
${ }^{29}$ Nesta planilha, as grades que aparecem à direita correspondem às totalizações dos marcadores acima delas e servem para indicar a quantidade de ocorrências para a categoria definida conforme as situações mais comuns de uso. Dessa forma, os marcadores conversacionais computados na categoria formam o conjunto de exemplares nela contido.
} 
Marcador C Linha

$\begin{array}{lll}41 & 42 \quad 43\end{array}$

creo que (A)

0

creo que (B)

6

creo que $(A+B)$

pienso que $(A)$

$\begin{array}{llll}6 & 0 & 0 & 0\end{array}$

pienso que $(B)$

0

pienso que $(A+B)$

$\begin{array}{llll}2 & 1 & 0 & 0\end{array}$

es cierto que $(A)$

0

es cierto que (B)

0

es cierto que $(A+B)$

0

acho (A)

0

acho (B)

0

acho $(A+B)$

Introduz Opinião $(A)$

Introduz Opinião (B)

Introduz Opinão $(A+B)$

en realidad $(A)$

en realidad $(B)$

0

en realidad $(A+B)$

Opinião "Neutra" (A)

Opinião "Neutra" (B)

Opinião "Neutra" (A)

\begin{tabular}{|c|c|c|c|}
\hline$?$ & $\mathbf{1}$ & 0 & \\
\hline & 0 & 0 & \\
\hline & 1 & 0 & \\
\hline
\end{tabular}

0

$0 \quad 0$

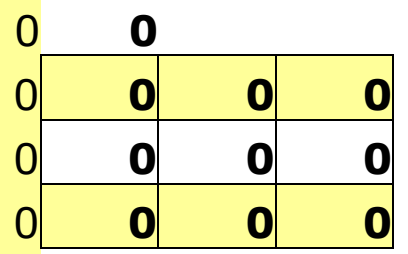

pero $(A)$

6

pero $(B)$

2

pero $(A+B)$

8

$\operatorname{mas}(A)$

2

mas $(B)$

$\operatorname{mas}(A+B)$

2

más bien $(A)$

$\begin{array}{lll}0 & 0 & 0\end{array}$

más bien (B)

0

más bien $(A+B)$

0

(en) contrario $(A)$

0

(en) contrario $(B)$

0

(en) contrario $(A+B)$

0

Outros (no, en absoluto etc) (A)

0

Outros (no, en absoluto etc) (B)

0

Outros (no, en absoluto etc) $(A+B)$

0

Oposição $(A)$

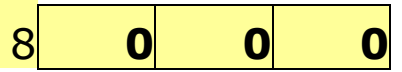


Oposição (B)

Oposição $(A+B)$

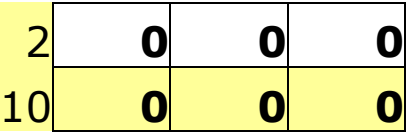

As quarenta linhas correspondem, em média, a três minutos de texto oral, fato este que serve para uma relação entre a freqüência totalizada e o tempo.

O comportamento da distribuição dos marcadores frente ao tópico discursivo também é objeto de interesse da pesquisa e, para que se pudesse investigá-lo, foi feita a secção do conteúdo das planilhas seguindo as divisões dos tópicos articulados no texto oral, dando assim subsídios para que se calculassem as freqüências relativas para os gráficos analisados neste trabalho.

Assim, na Planilha 5A o tópico de introdução à temática estava contido até a décima linha. A partir dessa linha, até a vigésima, consideramos a primeira argumentação voltada para restringir o âmbito da discussão.

A título de exemplo do procedimento de acompanhamento das freqüências relativas, apresentamos os gráficos ${ }^{30}$ que se seguem, sendo que as categorias introdução de opinião, oposição, acordo, operadores lógicos básicos e intervenção são descritas na legenda de 1 a 5 , seguindo a ordem, respectivamente.

\footnotetext{
30 Os gráficos referem-se ao total fatiado de marcadores por Tópico Discursivo desenvolvido durante a conversação. Os números de 1 a 5 , à direita do gráfico, são as indicações das categorias representadas segundo a porcentagem de aparecimento dos marcadores de cada uma delas no total apresentado. São elas: 1. Introdutores de opinião; 2. Oposição; 3: Acordo; 4: Operadores Lógicos Básicos; 5: Intervenção.
} 


\section{Freqüências Relativas dos Marcadores na Introdução ao Tema}

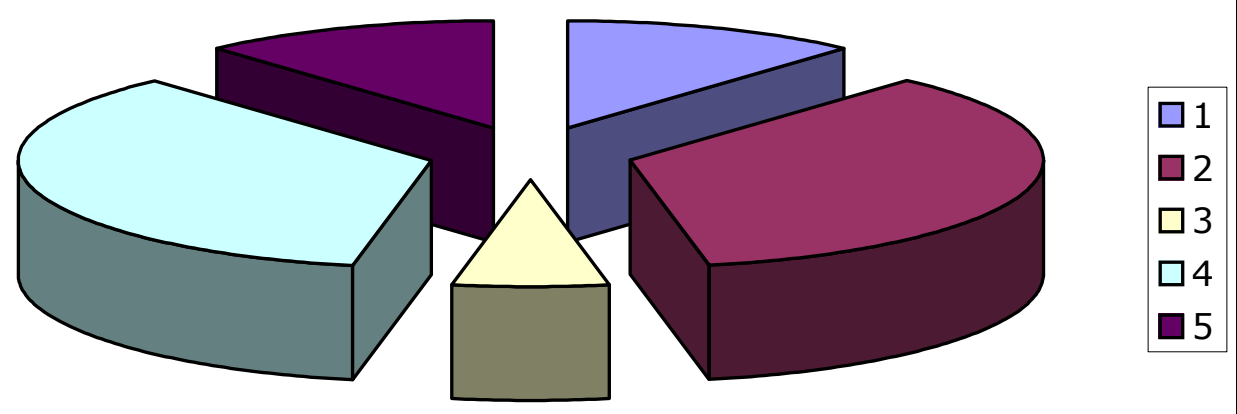

\section{Freqüências Relativas dos Marcadores na Argumentação Inicial}

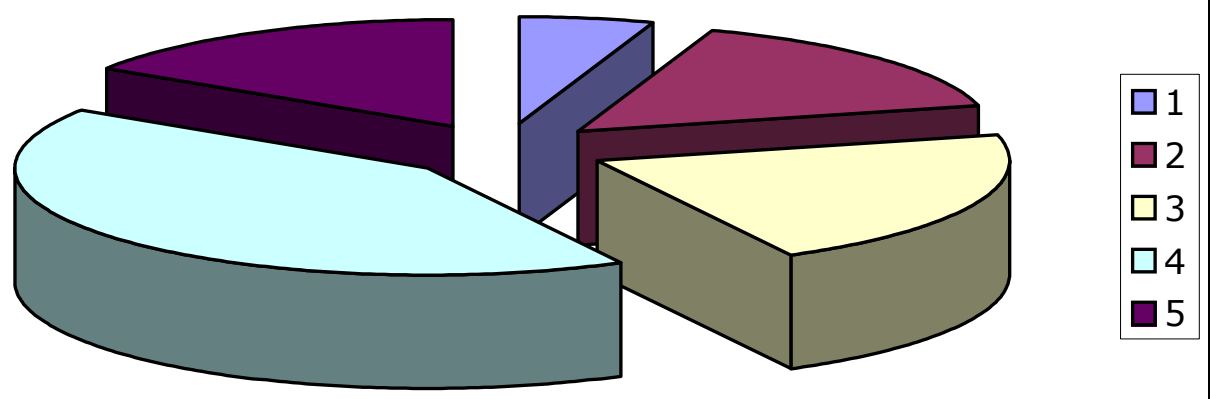

É importante notar que, para dar condições de visualização, os marcadores foram considerados em categorias, escolhidas arbitrariamente, seguindo as possibilidades semânticas mais comuns decorrentes do emprego deles. Para este tipo de análise não se distinguem os falantes: toma-se o número de ocorrências 
de cada categoria de marcador do texto transcrito entre as linhas que delimitam o tópico.

Já os canais receberam o tratamento de acumulação de freqüências para permitir a avaliação do emprego totalizado dos marcadores conversacionais empregados no texto oral até o momento em que se pretende fincar atenção para análise.

Desta forma, pode-se verificar o repertório acumulado, a cada linha, por marcador e por canal. Segue-se, como exemplo, uma planilha de freqüência acumulada da Planilha 5A:

\begin{tabular}{l} 
Marcador $C \backslash$ Linha \\
creo que $(A)$ \\
creo que $(B)$ \\
creo que $(A+B)$ \\
pienso que $(A)$ \\
pienso que (B) \\
pienso que (A+B) \\
es cierto que $(A)$ \\
es cierto que (B) \\
es cierto que $(A+B)$ \\
acho (A) \\
acho (B) \\
acho (A +B) \\
\hline Introduz Opinião $(A)$ \\
Introduz Opinião $(B)$ \\
\hline Introduz Opinão $(A+B)$ \\
\hline
\end{tabular}

$\begin{array}{lllllllllr}\mathbf{1} & \mathbf{2} & \mathbf{3} & \mathbf{4} & \mathbf{5} & \mathbf{6} & \mathbf{7} & \mathbf{8} & \mathbf{9} & \mathbf{1 0} \\ \mathbf{0} & \mathbf{0} & \mathbf{0} & \mathbf{0} & \mathbf{0} & \mathbf{0} & \mathbf{0} & \mathbf{0} & \mathbf{0} & \mathbf{0} \\ \mathbf{0} & \mathbf{0} & \mathbf{0} & \mathbf{0} & \mathbf{0} & \mathbf{0} & \mathbf{0} & \mathbf{0} & \mathbf{1} & \mathbf{1} \\ \mathbf{0} & \mathbf{0} & \mathbf{0} & \mathbf{0} & \mathbf{0} & \mathbf{0} & \mathbf{0} & \mathbf{0} & \mathbf{1} & \mathbf{1} \\ \mathbf{1} & \mathbf{1} & \mathbf{1} & \mathbf{1} & \mathbf{1} & \mathbf{1} & \mathbf{1} & \mathbf{1} & \mathbf{1} & \mathbf{1} \\ \mathbf{0} & \mathbf{0} & \mathbf{0} & \mathbf{0} & \mathbf{0} & \mathbf{0} & \mathbf{0} & \mathbf{0} & \mathbf{0} & \mathbf{0} \\ \mathbf{1} & \mathbf{1} & \mathbf{1} & \mathbf{1} & \mathbf{1} & \mathbf{1} & \mathbf{1} & \mathbf{1} & \mathbf{1} & \mathbf{1} \\ \mathbf{0} & \mathbf{0} & \mathbf{0} & \mathbf{0} & \mathbf{0} & \mathbf{0} & \mathbf{0} & \mathbf{0} & \mathbf{0} & \mathbf{0} \\ \mathbf{0} & \mathbf{0} & \mathbf{0} & \mathbf{0} & \mathbf{0} & \mathbf{0} & \mathbf{0} & \mathbf{0} & \mathbf{0} & \mathbf{0} \\ \mathbf{0} & \mathbf{0} & \mathbf{0} & \mathbf{0} & \mathbf{0} & \mathbf{0} & \mathbf{0} & \mathbf{0} & \mathbf{0} & \mathbf{0} \\ \mathbf{0} & \mathbf{0} & \mathbf{0} & \mathbf{0} & \mathbf{0} & \mathbf{0} & \mathbf{0} & \mathbf{0} & \mathbf{0} & \mathbf{0} \\ \mathbf{0} & \mathbf{0} & \mathbf{0} & \mathbf{0} & \mathbf{0} & \mathbf{0} & \mathbf{0} & \mathbf{0} & \mathbf{0} & \mathbf{0} \\ \mathbf{0} & \mathbf{0} & \mathbf{0} & \mathbf{0} & \mathbf{0} & \mathbf{0} & \mathbf{0} & \mathbf{0} & \mathbf{0} & \mathbf{0} \\ \mathbf{1} & \mathbf{1} & \mathbf{1} & \mathbf{1} & \mathbf{1} & \mathbf{1} & \mathbf{1} & \mathbf{1} & \mathbf{1} & \mathbf{1} \\ \mathbf{0} & \mathbf{0} & \mathbf{0} & \mathbf{0} & \mathbf{0} & \mathbf{0} & \mathbf{0} & \mathbf{0} & \mathbf{1} & \mathbf{1} \\ \mathbf{1} & \mathbf{1} & \mathbf{1} & \mathbf{1} & \mathbf{1} & \mathbf{1} & \mathbf{1} & \mathbf{1} & \mathbf{2} & \mathbf{2}\end{array}$

Para a avaliação do grau de compartilhamento do repertório, ou seja, a verificação do quanto representa o repertório compartilhado (com marcadores que são empregados pelos dois falantes) frente ao conjunto repertório total, convêm 
que se busque as colunas totalizadoras, como a que está abaixo (referente à Planilha 5A para as 40 primeiras linhas):

$\begin{array}{ll}\text { creo que }(A) & 0 \\ \text { creo que }(B) & 6 \\ \text { creo que }(A+B) & 6 \\ \text { pienso que }(A) & 2 \\ \text { pienso que (B) } & 0 \\ \text { pienso que }(A+B) & 2 \\ \text { es cierto que }(A) & 0 \\ \text { es cierto que (B) } & 0 \\ \text { es cierto que }(A+B) & 0 \\ \text { acho (A) } & 0 \\ \text { acho (B) } & 0 \\ \text { acho (A +B) } & 0 \\ \text { Introduz Opinião }(A) & 2 \\ \text { Introduz Opinião }(B) & 6 \\ \text { Introduz Opinão }(A+B) & 8\end{array}$

\section{Análise dos Resultados}

Os anexos nos mostram que:

1. A relação marcadores pelo léxico total aumenta para os falantes com menor participação no texto oral;

2. No total das transcrições só foi observado um número restrito de 26 marcadores distintos, sendo incluído aqui o uso do né, mas e outros do português);

3. Do conjunto repertório dos marcadores considerando o corpus todo, só 
6 marcadores estiveram presentes em todos os textos (empregados, portanto, por todos os falantes), a saber: creo que, pero, pausa preenchida, por que, no;

4. Aproximadamente $20 \%$ dos marcadores usados num texto oral são do conjunto repertório de apenas um dos dois falantes;

5. Os 6 marcadores presentes em todos os textos representam, aproximadamente, até $40 \%$ do conjunto repertório de um texto oral;

6. Entretanto, dos marcadores compartilhados pelas duplas de falantes, ou seja, aqueles que pertencem aos dois conjuntos repertórios num texto oral são, em média, $75 \%$ do conjunto repertório de marcadores total do texto;

7. O emprego de marcadores é diferente em freqüência relativa e tipo em função da temática do tópico da conversação;

8. Até os 3 primeiros minutos de conversação pelo menos $75 \%$ dos tipos de marcadores que serão usados no restante da conversação já foram empregados;

9. Até os 2 primeiros minutos de conversação pelo menos $50 \%$ dos tipos de marcadores que serão usados no restante da conversação já foram empregados;

10. Existe um processo de climatização dos marcadores da língua 1 para o emprego na língua 2; ou seja, o aluno faz adaptações do marcador de língua portuguesa para o de língua espanhola, com o intuito de "espanholizá-lo" dentro do discurso na língua alvo. Nesse sentido, acreditamos que exista uma espécie de princípio de preservação 
subconsciente para se garantir a manutenção da língua alvo quando em situações de diálogo entre os aprendizes de língua estrangeira. A preservação estaria relacionada tanto à manutenção da língua a que se propõe como da sua própria imagem positiva;

11. Aprendizes de espanhol, ao tentar praticar um diálogo na língua alvo, apresentam, em geral, um conjunto repertório maior do que em sua língua materna; uma vez que utilizam os marcadores de ambas as línguas e os de climatização, ou seja, os criados no momento da conversação;

12. Aprendizes de espanhol, ao desenvolverem um diálogo na língua alvo, apresentam, em geral, um conjunto repertório maior do que os falantes nativos da língua alvo, isto quer dizer que incorporam também as suas próprias criações;

13. A curva obtida a partir dos dados do número de elementos do conjunto repertório por tempo, indica que, rapidamente, alcança-se um platô, ou seja, o conjunto repertório de marcadores de um falante é finito se for considerada uma conversação tão longa quanto se queira.

Podemos separar os resultados em duas categorias distintas de conseqüências: a que diz respeito às estratégias de emprego dos marcadores para a composição adequada de um texto oral e aquela que está relacionada à maneira como se estabelece o repertório dos marcadores a ser empregado numa conversação.

É bem verdade que parece existir uma profunda relação entre as duas conseqüências, entretanto, considerá-las em separado é conveniente, pois a primeira categoria diz respeito à capacidade de desempenho do falante frente aos 
diversos contextos que se lhe apresentam e a segunda faz referência ao desencadeamento (bootstrapping).

Pudemos constatar que existe relação entre a conformação do tópico em que se desenvolve o texto oral e as freqüências relativas dos marcadores conversacionais. Assim, tópicos em que existe uma atitude pragmática de proteção de face têm um incremento nas freqüências relativas de marcadores que se associam aos blocos textuais em oposição, bem como daqueles que sugerem um acordo, mesmo que parcial. Entendemos que tal fato decorra da intenção dos falantes de evitar uma tomada de posição, o que em alguns casos pode resultar num bloco compacto de marcadores como os que indicamos abaixo:

36Doc.: vosotros traicionaríais?

37A: empiezas tú...(risos)

38B: ah yo... (risos) no:.... creo que no... nunca ocurrió:: ahm... este:.:: tipo de 39cosa:.: creo/como lo dice antes...creo que no llegaría a este punto....

40A: yo también no... pero creo que las cosas... eh... se van ocurriendo...(risos) 41 (de los) momentos...né

42B: los momentos...

43A: sí...pero:: también no... ((risos))

44B: no llegaría...

45A: no (risos)

46B: no sé... no sé... solamente quien vive...

47A: sí...

(Fragmento daTranscrição da Fita 2A) ${ }^{31}$

Outros tópicos, como os de introdução temática ou como os argumentativos respondem de forma similar mostrando que existe um ajuste entre o texto e o seu

${ }^{31}$ Ver anexo 5 
contexto de enunciação não apenas na escolha lexical, mas também na escolha dos marcadores.

Na introdução temática, os marcadores que introduzem opinião apresentam freqüência relativa maior do que, por exemplo, o que se encontra na narração de um caso requisitado pela documentadora, como observamos na transcrição da Fita 1B.

Os marcadores de introdução de opinião precedem o texto oral requisitado pela documentadora, como se pode observar:

1A: BUEno... creo que:::.... si ella está::... eh...si ella es infiel con con el 2marido... con el esposo...es porque no... no... ahm...eh... es porque no está 3más enamorada de él...(risos)

Em gráficos para relacionar as freqüências relativas, como dos que dispomos a seguir ${ }^{32}$, podemos perceber, através do exemplo da transcrição da Fita 1B, como a freqüência relativa dos marcadores que introduzem opinião (em 1 - azul claro) é completamente diferente durante a introdução da temática (primeiro gráfico) e durante a narração de um exemplo (segundo gráfico), ambas desenvolvidas na conversação.

\footnotetext{
${ }^{32}$ Os números, à direita, correspondem aos marcadores de cada categoria analisada, a saber: 1 . Introduz opinião; 2. Opinião neutra; 3. Oposição; 4. Interjeições e vocativos; 5. Acordo, explicação ou restrição; 6. Operadores lógicos básicos; 7. Interferência e 8. Tentativas de Interferência.
} 

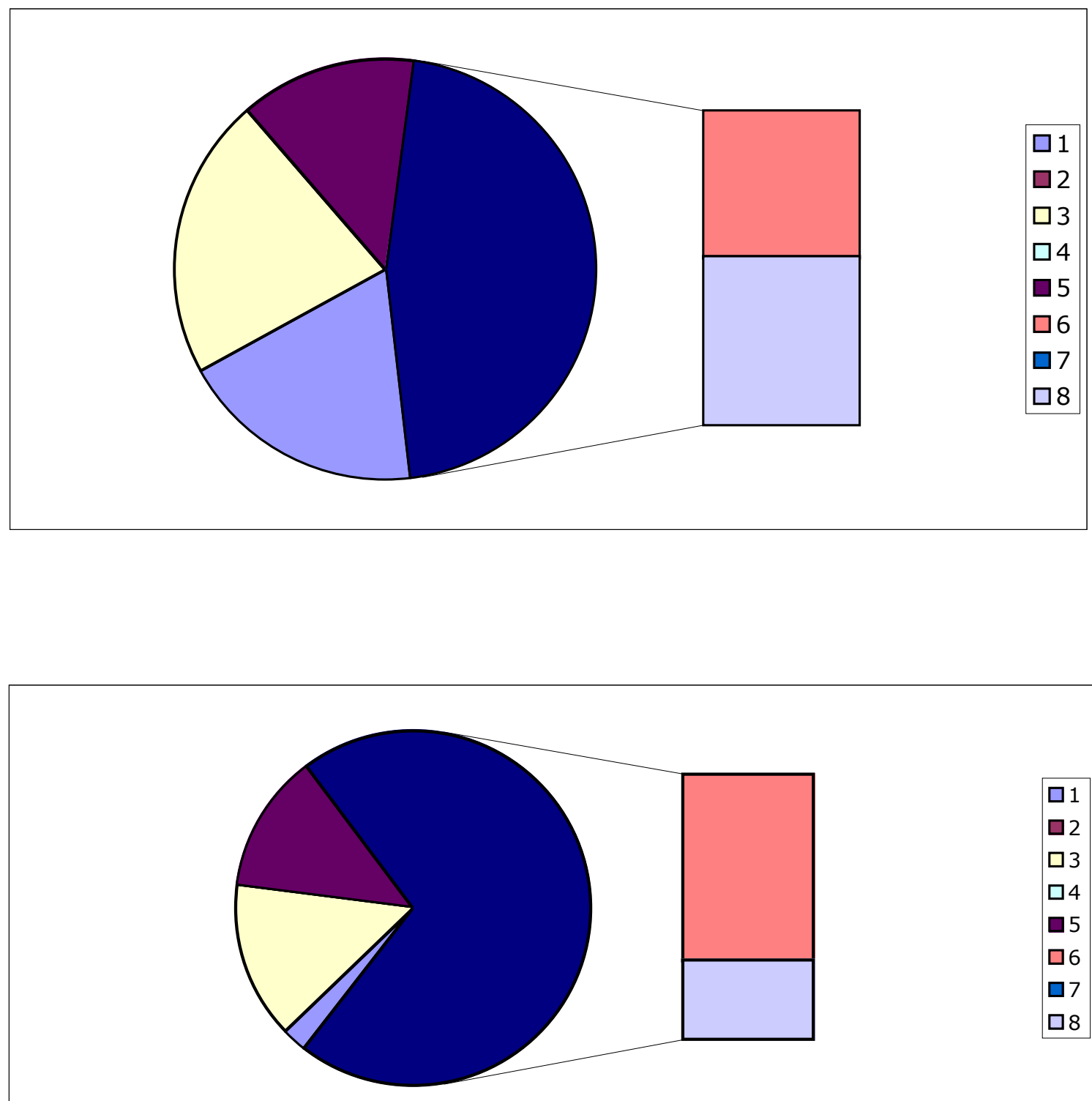

Outra constatação relativa às estratégias voltadas à adequação é aquela referente ao compartilhamento do repertório.

Os resultados mostram que apenas um grupo restrito de marcadores pertencentes ao repertório total empregado pelos falantes, no seu texto oral completo, também pode ser encontrado em outros diálogos, compartilhado por todos os demais falantes. Entretanto, o compartilhamento de marcadores em todas as conversações analisadas é da ordem de $75 \%$ o que indica que, em virtude de se tratar de tema comum em todos os depoimentos, os interlocutores 
mantém uma estratégia de ajustamento dos seus repertórios durante a enunciação.

Um caso ilustrativo desse fato é o que encontramos na transcrição da fita 2 A. Nela, pode-se notar que até a linha 90 o falante $A$ havia empregado 7 vezes 0 marcador né, enquanto que o falante B não mostrou inclinação para empregá-lo. Contudo, a partir desse momento, o falante $B$ começa a empregá-lo também, como ilustramos a seguir com o trecho da planilha:

né $(A+B)$

Convém notar que o marcador né foi pouco empregado pelos falantes que participaram dos depoimentos. Mais precisamente, 3 dos 16 falantes empregaram esse marcador, perfazendo $18,75 \%$ da amostra. A probabilidade de encontrarmos um par é da ordem de $3,5 \%$.

Ainda devemos lembrar que, até a linha 90, acima de 90\% do repertório do texto oral final já foi empregado no texto realizado até então, o que sugere a não disposição de $\mathrm{B}$ em construir o seu texto com esse marcador.

A atitude de B representa bem a explicação dada aqui para a porcentagem alta de compartilhamento de marcadores, ou seja, existe alguma forma de ajuste de repertórios durante a enunciação.

Esta estratégia é tão mais intensa quão maior é o grau de colaboração existente entre os falantes para construir o texto oral. Isto sugere que a coesão do texto oral completo também está relacionada à capacidade de uniformização dos marcadores usados pelos falantes. 
Entretanto, a estratégia apontada acima só seria possível se os falantes pudessem, com rapidez, conhecer o repertório que será empregado na conversação. É aí que se faz a imbricação das duas categorias de conseqüências, pois o desencadeamento rápido do emprego dos marcadores do conjunto repertório, permite que se suponha a consistência da estratégia de ajuste.

Em todas as fitas, pode-se notar que o início da conversação apresenta uma grande variedade de marcadores frente ao total que se costuma encontrar.

Um aspecto particular da dinâmica de realização do repertório ocorre, no caso de emprego dos marcadores por parte de aprendizes de espanhol quando buscam desenvolver o texto oral e não encontram os recursos necessários para fazê-lo, mais especificamente, na prática da formação de um subconjunto do repertório relativo aos marcadores que não pertencem à língua alvo, como né, mas, ainda mais, depende, ainda que (pertencentes à língua de partida) ou como no es, a pesar que, ainda más, cujo emprego resulta de um ato de criação individual que toma como base marcadores conhecidos e um aparente conhecimento do sistema da língua alvo. A esses marcadores chamaremos de marcadores de transição para facilitar a sua identificação. $O$ quadro 3 oferece um exemplo em que se pode observar uma lista dos marcadores encontrados na Fita 2B aos quais denominamos "de transição" por serem tanto do português como do espanhol, incluídos aqueles que consideramos climatizados, resultantes das adaptações realizadas pelos alunos na tentativa de manterem o código lingüístico da língua alvo ${ }^{33}$. Em outras palavras, a interlíngua inclui, mas não exclui os marcadores das línguas envolvidas, bem como cria novos através da mescla das línguas. Os Quadros 1 e 2 apresentam uma mostra dos marcadores de língua espanhola e portuguesa, respectivamente, a título de comparação com os da interlíngua apresentados.

\footnotetext{
${ }^{33}$ Os números que aparecem entre parêntesis, ao lado dos marcadores, representam o número de vezes que esses marcadores aparecem no texto selecionado. Os que não apresentam números apareceram uma única vez.
} 


\begin{tabular}{|c|c|}
\hline $\begin{array}{c}\text { Quadro 1 } \\
\text { MARCADORES DO ESPANHOL } \\
\text { PENINSULAR } \\
\text { Anexo 1 } \\
\text { (fala periférica) } \\
\end{array}$ & $\begin{array}{c}\text { Quadro 2 } \\
\text { MARCADORES DO PORTUGUÊS DO } \\
\text { BRASIL } \\
\text { Anexo 2 } \\
\text { (fala culta) }\end{array}$ \\
\hline Que $(3 x)$ & Não? (2x) \\
\hline A ver & Ahn ahn $(4 x)$ \\
\hline Pero $(2 \mathrm{x})$ & É que $(2 x)$ \\
\hline Cómo quiés decir? ${ }^{34}$ & Não é? $(2 x)$ \\
\hline Ay $(3 x)$ & Nossa \\
\hline Sí (4x) & Que chique \\
\hline ¿No? (3x) & Então $(2 x)$ \\
\hline Por qué & Quer dizer \\
\hline Eh $(3 x)$ & Acho que \\
\hline Oye $(3 x)$ & Dado que \\
\hline Pues & E Daí \\
\hline Vaya & Exatamente \\
\hline Es que yo no & É $(2 x)$ \\
\hline Seguro & Mas \\
\hline Es que a (mi marido) & Né? \\
\hline Qué bien! & Justamente \\
\hline claro & Porque \\
\hline & $E(2 x)$ \\
\hline
\end{tabular}

${ }^{34}$ Variante valenciana do espanhol peninsular. 


\begin{tabular}{|c|}
\hline Quadro 3 \\
MARCADORES DA INTERLÍNGUA DE APRENDIZES DE ESPANHOL \\
Anexo 3 - Fita 2B \\
Bien \\
\hline Creo que (3x)/ Creo que no \\
\hline A favor de \\
Porque (2x) \\
\hline Eh \\
\hline Si \\
\hline Ainda más \\
\hline Es una cosa que yo \\
\hline En mi opinion \\
\hline A pesar / a pesar que (2x) \\
\hline Así (2x) \\
\hline Yo también no \\
\hline Depende \\
\hline No sé (2x) \\
Mas \\
\hline Y \\
\hline Tá bien \\
\hline Pienso (lo mismo) \\
\hline ah \\
\hline Entonces \\
\hline pero \\
\hline
\end{tabular}

Conforme já assinalamos, os dados nos permitem dizer que a atividade de construção de um subconjunto do repertório que não pertence ao sistema da língua alvo não gera marcadores compartilhados. Muito pelo contrário, os elementos que surgem com papel de marcadores, mas que não pertencem à língua alvo, passam a constituir um traço específico do indivíduo que os criou, mesmo quando são repetidos largamente.

Tal fato é curioso, pois não parece ser obstáculo ao entendimento o emprego dos marcadores de transição, ou seja, em nenhum momento, o falante que fez uso do expediente foi requisitado a dar explicações a respeito do enunciado que proferiu, mas, raramente, o interlocutor se apropriou do marcador em questão. 
É importante frisar que a compreensão textual apontada reflete a situação em que os falantes são todos aprendizes, com a mesma língua de partida, em processo de produção de textos numa mesma língua alvo.

Notamos que a mesma situação não tem garantida a compreensão do texto produzido, quando os mesmos aprendizes, ao compor o texto oral, empregam marcadores de transição e têm, como interlocutores, falantes do espanhol não bilíngües. 


\section{CONSIDERAÇÕES FINAIS}


A busca de padrões relativos ao emprego dos marcadores conversacionais em situação de ensino aprendizagem de língua espanhola para estudantes brasileiros resultou na constatação de alguns atributos, cuja constância é relevante para a adequação da composição do texto oral ao contexto pragmático da enunciação.

Assim, pode-se dizer que existe um número relativamente pequeno de marcadores que compõem o conjunto repertório, dentre os quais, aproximadamente $75 \%$ dos seus elementos são compartilhados pelos interlocutores. Tal fato faz com que o texto oral se apresente homogêneo, ou seja, difícil de se determinar os responsáveis pelos turnos quando não há indicação explícita. Constitui, portanto, num atributo responsável pela coesão do texto oral, mesmo quando a sua composição decorre de intensa colaboração.

O compartilhamento indicado é muito maior entre dois falantes do que aquele que encontramos se reunimos todos os textos orais e investigamos a ocorrência de emprego de cada marcador por todos os falantes (compartilhamento total). Este fato mostra que existe alguma estratégia de ajustamento, por parte dos falantes, dos respectivos repertórios de marcadores.

Os dados a respeito de cada repertório, necessários para a existência da estratégia citada, são decorrentes da maneira como ocorre o desencadeamento do emprego dos marcadores conversacionais no curso da composição do texto oral estando, colaborativamente, inseridos no texto, pelo menos $50 \%$ dos elementos do conjunto repertório em até 2 minutos de conversação e $75 \%$ em até 3 minutos.

Dessa forma, compreendemos que a estratégia adotada pelos falantes aprendizes, capaz de homogeneizar a composição do texto oral colaborativo, deve se beneficiar dos instantes iniciais da conversação, pois o bootstrapping é um fenômeno constatável no emprego dos marcadores conversacionais. 
Esta constatação sugere que os falantes que não interagem no início da conversação correm o risco de ficarem a mercê de conjuntos de repertórios não favoráveis ao seu desempenho lingüístico.

Em tempo, pode-se dizer que estratégias de ensino aprendizagem podem ser voltadas para que o aprendiz tire o máximo proveito dos instantes iniciais da conversação, de tal forma que também apresente o seu repertório e possa se beneficiar do desencadeamento do texto oral, através de um processo contínuo de composição textual colaborativa.

Por outro lado, é recomendável que o professor insista nas correções dos marcadores de transição, para evitar que eles se propaguem durante a conversação, o que poderá induzir à fossilização do erro.

Pode-se afirmar que, a despeito da parca carga semântica atribuída ao marcador conversacional em sua individualidade, quando não está inserido no texto oral, a sua freqüência de uso dependerá sempre do tópico abordado.

Por conseguinte, fazer o aprendiz observar com cuidado a adequação do emprego dos marcadores ao contexto enunciativo permite que o seu texto oral possa ter uma leitura mais eficiente por parte do interlocutor.

De posse da estratégia de composição apontada, observamos, em síntese, que o texto oral obtido torna-se consistente, tessitura e legibilidade em função do pareamento e da rápida constituição do conjunto repertório.

A observação do pareamento de marcadores conversacionais utilizados pelos falantes em processo de aquisição/aprendizagem de língua estrangeira indica uma forte possibilidade de que o mesmo ocorra entre os falantes nativos de uma língua. Dentro da perspectiva textual-interativa, as situações de pareamento representam uma nítida relação de interação, consciente ou não, mas que 
refletem uma tendência à externalização do pensamento humano no intuito de se obter o êxito comunicativo. Os resultados obtidos nesta pesquisa apontam para o fato de que os aprendizes criam estratégias comuns e apresentam padrões no desencadeamento do uso dos marcadores e contribuem para os estudos em torno à aquisição/aprendizagem de línguas e para o desenvolvimento de estratégias de ensino que desenvolvam uma maior competência lingüística e conversacional. 
REFERÊNCIAS BIBLIOGRÁFICAS 
ALCARAZ,E.; MARTÍNEZ-LINARES, M.A. Diccionario de lingüística moderna. Madrid: Ariel, 1997.

ANDRADE, M.L.C.V.O. Contribuição à gramática do português falado: estudo dos marcadores conversacionais então, aí, daí. Dissertação de mestrado, Pontifícia Universidade Católica de São Paulo: 1990.

AUSTIN, J.L. (1970) Ensayos filosóficos. Madrid: Revista de Occidente, 1975. . How to do things with words. Oxford: University Press, 1962.

BAKHTIN, M. (Volochínov) Marxismo e filosofia da linguagem. São Paulo: Hucitec, 1981.

BARALO, M. La adquisición del español como lengua extranjera. Madrid: Arco/Libros, 1999.

BENVENISTE, E. Problemas de Lingüística Geral. 2ª ed. Campinas, SP: Pontes, 1989.

BRIZ-GÓMEZ, A. El español coloquial en la conversación. Esbozo de pragmagramática. Barcelona: Ariel, 1998.

; GRUPO VAL.ES.CO. Oralia. Corpus de Conversaciones

Coloquiales. Madrid: Arco/Libros, 2002.

; HIDALGO, A. Conectores pragmáticos y estructura de la conversación. In: ZORRAQUINO, M.A.M. \& DURÁN, E.M. (Org.) Los marcadores del discurso. Teoría y análisis. Madrid: Arco/Libros, 1988.

CALLIGARIS, C. Hello Brasil! Notas de um psicanalista europeu viajando ao Brasil. São Paulo: Escuta, 1992.

CARIONI, L. Aquisição de segunda língua: a teoria de Krashen. In: BOHN, H.I. \& VANDRESEN, P. Tópicos de lingüística aplicada - o ensino de línguas estrangeiras. Florianópolis: Ed. da UFSC, 1988.

CASTILHO, A. T. de. A língua falada no ensino de português. São Paulo, Contexto, 2000.

; PRETI, D. (Org.) A linguagem falada culta na cidade de São Paulo. Diálogos entre dois informantes. São Paulo: T.A. Queiroz/ FAPESP, 1987, vol. 2.

CENOZ-IRAGUI, J. El concepto de competencia comunicativa. In: SÁNCHEZ LOBATO, J.; SANTOS GARGALLO, I. Vademécum para la formación de profesores - Enseñar Español como lengua (L2)/lengua extranjera (LE). Madrid: SGEL, 2004, p. 449-463. 
CHARAUDEAU, P.; MAINGUENEAU, D. Dicionário de Análise do Discurso. Trad. Fabiana Komesu (Coord.), 2a . ed. São Paulo: Contexto, 2006.

CORDER, S. P. Dialectos idiosincrásicos y análisis de errores. In: LICERAS, J. M. La Adquisición de las Lenguas Extranjeras - Hacia un Modelo de Análisis de La Interlengua. Madrid: Fuenlabrada, 1991.

COSERIU, E. (1967) Teoría del lenguaje y lingüística general. 2ª . ed. reimp. Madrid: Gredos, 1969.

. La configuración de la competencia lingüística. In:

Competencia lingüística - Elementos de la teoría del hablar. Ed. Heinrich Weber, Versão espanhola de Francisco Meno Blanco. Madrid: Gredos, 1983.

COULTHARD, M. et alii. Development a description of spoken Discourse. In: ; MONTGOMERY, M. (Ed.). Studies in discourse analysis. Londres: Routledge/ Kegan Paul, 1981.

CHOMSKY, N. Rules and Representations, Oxford: Blackwell, 1980.

Aspects of theory of Syntax. Cambridge, Mass: MIT Press, 1965.

CHRISTL, J. Muletillas en el español hablado. In: KOTSCHI, T. et alii. El español hablado y la cultura oral en España e Hispanoamérica. Madrid: Instituto Iberoamericano; Frankfurt: Vervuert, 1996, p. 117-143.

CORRÊA, L. M. S. Conciliando processamento lingüístico e teoria de língua no estudo da aquisição da linguagem. In: (Org). Aquisição da linguagem e problemas do desenvolvimento lingüístico. Rio de Janeiro: Editora PUC-Rio; São Paulo: Loyola, 2006, p.21-78.

Aquisição da Linguagem: uma retrospectiva dos últimos trinta anos. In: Trinta anos de Abralin. Delta, vol.15, Número Especial, 1999, p. 339-383.

DABÈNE, L. Repères sociolinguistiques pour l'enseignement des langues. Paris: Hachette, 1994.

DERDYC, E. Formas de pensar o desenho. Desenvolvimento do grafismo infantil. São Paulo: Scipione, 1994.

DUCROT, O. (1972) Princípios de semântica lingüística: dizer e não dizer. São Paulo: Cultrix, 1977. Trad. do original Dire et ne pas dire, Principes de sémantique linguistique. Paris: Hermann.

EDMONDSON, W.; HOUSE, J. Basis for the Description of Conversation as an Interactive Process. In: Let's talk, and talk about it. A pedagogic interactional grammar of English. Munique/Viena/Baltimore: Urban \& Schwazenberg, 1981, p. 35-68. 
ESCANDELL-VIDAL, M.V. (1996) Introducción a la pragmática. Barcelona: Ariel, 2002.

FÁVERO, L.; ANDRADE, M.L.C.V.O.; AQUINO, Z.G.O. O par dialógico perguntaresposta. In: JUBRAN, C.C.A.S.; KOCH, I.G.V. (Org.) Gramática do português culto falado no Brasil. Construção do texto falado. Campinas, SP: Ed. da Unicamp, p. 133-166, 2006, vol.1.

FERNÁNDEZ-LÓPEZ, S. Las estrategias de aprendizaje. In: SÁNCHEZ LOBATO, J.; SANTOS GARGALLO, I. Vademécum para la formación de profesores Enseñar Español como lengua (L2)/lengua extranjera (LE). Madrid: SGEL, 2004, p.411-433.

FUENTES-RODRÍGUEZ, C. Lingüística pragmática e Análise do discurso. Madrid, Arco/Libros, 2000.

FRASER, B. Conversational Mitigation. In Journal of Pragmatics 4: 341-350, 1980.

GALLARDO-PAÚLS, B. Comentario de textos conversacionales. De la teoría al comentario. Colección Comentario de Textos. Madrid, Arco/Libros, 1998, v.1.

GARCÍA-GARCÍA, M. (2004) La competencia conversacional en los estudiantes de español como lengua extranjera. Revista Eletrónica LinRed - Lingüística en la red. Disponível em

$<$ http://www2.uah.es/linred/articulos pdf/LR articulo 29122004.pdf> Citado em $01 / 01 / 2005$.

GILLETTE, J. GLEITMAN, H. GLEITMAN, L. \& LEDERER, A. Human simulations of vocabulary learning. Cognition, 73, 1999. p.165-176.

GLEITMAN, L. The structural sources of verb meanings. Language Acquisition, 1, 1990, p.3-55.

GONÇALVES, E. A presença de marcadores conversacionais na produção oral de língua estrangeira: estudo do caso de falantes do português do Brasil aprendizes de espanhol. Dissertação de mestrado, FFLCH/Universidade de São Paulo, 2000.

GOUT, A. E CHRISTOPHE, A. O papel do bootstrapping prosódico na aquisição da sintaxe e do léxico. In: CORRÊA, L.M.S. (Org.) Aquisição da linguagem e problemas do desenvolvimento lingüístico. Rio de Janeiro: Ed. PUC-Rio; São Paulo: Loyola, 2006, p. 103-127.

GRICE, P. Logic and Conversation. In: Studies in the way of words. Cambridge, Massachusetts; Harvard University Press, 1967, p. 23-137.

GULICH, E. Reformulierungshandlungean als Mittel der Textkomstitution. In: MOTSCH, W. , apud HILGERT, J.G. Procedimentos de reformulação: a paráfrase. In: PRETI, D. et alii (Org.) Análise de Textos Orais, 2a. ed. São Paulo: FFLCH/USP, 1987. 
GUMPERZ, J.J. Discourse strategies. Cambridge: Cambridge University Press, 1982.

; HYMES, D. Directions in Sociolinguistics: The etnography of

communication. New York: Hols, Reinhart and Winston, 1972.

GUSMÁN, J. C.; ROJAS, G. H. Implicaciones educativas de seis teorías psicológicas. México: Conalte, 1993.

HABERLAND, H. \& MEY, J. L. Editorial : linguistics and pragmatics. Journal of Pragmatics, Amsterdam, v.1, n.1, p.1-12, 1977.

HALLIDAY, M.A.K. (1973) As bases funcionais da linguagem. In: DASCAL, M. (Org.) Fundamentos Metodológicos da Lingüística - Concepções gerais da teoria lingüística. São Paulo: Global, 1978, vol. 1.

; MCINTOSH, A.; STREVENS, P. As ciências lingüísticas e o ensino de línguas. Trad. Myriam Freire Morau. Petrópolis: Vozes, 1974.

HILGARD, E.R.; ATKINSON, R.C. Introdução à psicologia. Rio de Janeiro: Companhia Editora Nacional, 1979.

HJELMSLEV, L. Ensaios lingüísticos. São Paulo: Perspectiva, 1991.

HYMES, D. Models of the interaction of language and social life. In: GUMPERZ, J.J. ; HYMES, D. (eds.). Directions in Sociolinguistics: Theetnography of communication. New York: Hols, Reinhart and Winston, 1972, p. 35-71.

JAKOBSON, R. Lingüística e comunicação. São Paulo, Cultrix, 1969.

KELLER, E. Gambits: conversational strategy signals. In: Journal of pragmatics, 3:219-238, 1979.

KRASHEN, S. Second Language Acquisition and Second Language Learning. Oxford: Pergamon Press, 1981.

KRASHEN, S. (1977) El modelo del monitor y la actuación de los adultos en L2. In: LICERAS, J.M. La adquisición de las lenguas extranjeras: Hacia un modelo de análisis de la interlengua. Trad. de Marcelino Marcos. Madrid: Visor, 1991, p. 143151. Do original: KRASHEN, S. The monitor model or adult second language performance. In: BURT, M., DULAY H.; FINOCCHIARO, M. (Ed.). New York: Regents, 1977, p. 152-161.

KUHL, P. A new view of language acquisition. Em PNAS, vol. 97, 22:11850-11857, 2000.

LABOV, W. The study of language in its social context. In: Studie Generale, vol. 23, p. 66-84, 1970. 
LEITE, M. Q. Língua falada: uso e norma. In: PRETI, D. (Org.) Estudos de Língua Falada: variações e confrontos. São Paulo: Humanitas, FFLCH/USP, 1998.

LEMLE, M. Comentários à conferência "Novos Horizontes no Estudo da Linguagem" de Noam Chomsky. Disponível em <http://www.letras.ufrj.br/clipsen/ipub.pdf> Citado em 18 de junho de 2006.

LEMOS, C.T.G. de. O erro como desafio empírico a abordagens cognitivas do uso da linguagem: o caso da aquisição de linguagem. In: ALBANO, E.; HADLER COUDRY, M. I. ; POSSENTI, S.; ALKMIN, T. (Org.) Saudades da Língua. Campinas, SP: Mercado de Letras, 2003, p. 515-534.

LOPE BLANCH, J.M. Análisis gramatical del discurso. Cidade do México, Universidad Nacional Autônoma de México, 1983.

MACEDO, A.V.T. DE et alii. Aquisição de marcadores em primeira e em segunda língua. In: RONCARATI, C.; MOLLICA, M.C. (Org.) Variação e aquisição. Rio de Janeiro, Tempo Brasileiro, 1997.

MAINGUENAU, D. Pragmática para o discurso literário. Trad. Marina Appenzeller. São Paulo: Martins Fontes, 1996.

MARCUSCHI, L.A. Marcadores conversacionais do português brasileiro: formas, posições e funções. In: CASTILHO, A.T. (Org.) O português culto falado no Brasil, Campinas, SP: Ed. Unicamp, 1989, p. 281-321.

Análise da Conversação. São Paulo: Ed.Ática, 1986.

MARTÍN-BUTRAGUEÑO, P. Hacia una descripción prosódica de los marcadores discursivos. Datos del español de México. In: Revista Electrónica PreseeaProyecto para el Estudio Sociolingüístico del Español de España y de América. Disponivel em $<$ http://www.linguas.net/preseea/contenido/documentos detalle.asp?cod=3\&Doc= 8 > Citado em 23 de novembro de 2006.

MARTÍN-MARTÍN, J.M. La adquisición de la lengua materna (L1) y el aprendizaje de una segunda lengua (L2)/Lengua extranjera (LE): procesos cognitivos y factores condicionantes. In: SÁNCHEZ LOBATO, J. E.; SANTOS GARGALLO, I. Vademécum para la formación de profesores: Enseñar Español como lengua (L2)/lengua extranjera (LE). Madrid: SGEL, 2004, p.261 a 286.

MARTÍN-ZORRAQUINO, MA. A.; MONTOLÍO-DURÁN, E. Los marcadores del discurso. Teoría y Análisis. Madrid, Arco/Libros, 1988.

MATTOSO CÂMARA JR., J. Manual de Expressão Oral e Escrita. 18ª . ed. Petrópolis: Vozes, 1986.

MELMAN, C. Imigrantes: Incidências subjetivas das mudanças de língua e país. São Paulo: Escuta, 1992. 
MOURA, H.M.M. Significação e Contexto. Uma introdução a questões de semântica e pragmática. Florianópolis: Insular, 2000.

NAME, M.C.; CORRÊA, L.M.S. Explorando a escuta, o olhar e o processamento sintático: metodologia experimental para o estudo da aquisição da língua materna em fase inicial. In: CORRÊA, L.M.S. (Org.) Aquisição da linguagem e problemas do desenvolvimento lingüístico. Rio de Janeiro: Ed. PUC-Rio; São Paulo: Loyola, 2006.

NARBONA-JIMÉNEZ, A. Sintaxis española: Nuevos y viejos enfoques. Barcelona: Ariel, 1989.

OS PENSADORES. Peirce. Escrito Coligados. 4⿳亠丷. ed., seleção de Armando Mora D`Oliveira e Sérgio Pomerangblum. São Paulo: Nova Cultural, 1989.

. Ryle, Strawson, Austin, Quine. 4⿳亠丷a . ed.. Seleção de textos de Oswaldo Porchat de Assis Pereira da Silva, trad. de Balthazar Barbosa Filho et alii. São Paulo: Nova Cultural, 1989.

. Willian James. Pragmatismo. $3^{\text {a }}$. ed., trad. Jorge Caetano da Silva. São Paulo: Nova Cultural, 1989.

- Kant. Crítica da razão pura. 3a․ ed., trad. Valério Rohden e Udo Baldur Moosburger. São Paulo: Nova Cultural, 1987.

PAPALIA, D. E.; OLMS, S.W. O mundo da criança. Trad. Maria Lúcia G.L.Rosa. 2ª . ed. São Paulo: Makron Books, 1998.

PEREIRA. I; MATA, A.I. E FREITAS, M.J. Estudos em prosódia. Lisboa: Colibri, 1992.

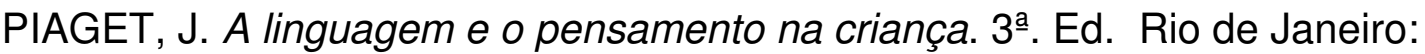
Fundo de Cultura, 1993.

PINTO, J.P. Pragmática. In: MUSSALIM, F.; BENTES, A.C. (Org.) Introdução à lingüística. Domínios e fronteiras. São Paulo: Cortez, 2001, vol. 2.

PRETI, D. Sociolingüística: os níveis de fala, $7^{\text {an }}$ ed. São Paulo: EDUSP, 1994.

. A Linguagem Falada Culta na Cidade de São Paulo:

Estudos. São Paulo: Ed. T.A. Queiroz/ FAPESP, 1990, vol. 4.

RICHARDS, J. The context of language teaching. Cambridge: Cambridge Universtiy Press, 1985.

RISSO, M.S. O articulador discursivo então. In: CASTILHO, A.T.; BASÍLIO, M.

(Org.) Gramática do Português Falado: Estudos descritivos, vol. IV. Campinas: Ed. da Unicamp; São Paulo: Fapesp, 1996, p. 423-451. 
; SILVA, G.M.O.; URBANO, H. Traços definidores dos marcadores

discursivos. In: JUBRAN, C.C.A.S.; KOCH, I.G.V. Gramática do português falado no Brasil: Construção do texto falado. Campinas: Ed. Unicamp, 2006, vol. 1.

ROMERA, M. (2003) Un análisis semántico del adverbio temporal entonces.

Revista Electrónica LinRed- Lingüística en la REd. Disponível em $<$ http://www2.uah.es/linred/articulos pdf/LR articulo 141120032.pdf > Citado em 14 de novembro de 2003.

ROSA, M. Marcadores de Atenuação. São Paulo: Contexto, 1992.

ROULET, E. Interaction markers in dialogue. In Applied linguistics. 1(3), p. 224233, 1980.

; AUCHLIN, A; MOESCHLER, J.; RUBATEL, C.; SCHELLING, M. L'articulation du discours en Français comtemporain. Berne: Peter Lang, 1985.

SACHS, H.; SCHEGLOFF, E. A.; JEFFERSON, G. A simplest systematics for the organization of turn-talking for conversation. In: Language, 50: 696-735, 1974.

SAID ALI, M. (1930) Meios de Expressão e Alterações Semânticas, 2ª . ed. Rio de Janeiro: Organização Simões, 1951.

SAUSSURE, F. (1916) Curso de Lingüística geral. Trad. de Antonio Chelini, José Paulo Paes e Izidoro Blikstein. São Paulo: Cultrix, 1997, do original Cours de Linguistic Gènerale. Ed. Bally, C; Sechehaye, A \& Riedlinger, A. Paris: Payot, 1916.

SCARPA, E.M. Sons preenchedores e guardadores de lugar: relações entre fatos sintáticos e prosódicos na aquisição da linguagem. In: Scarpa, E.M. (Org.) Estudos em prosódia. Campinas: Ed. da Unicamp, 1999, p. 253-279.

SCHEGLOFF, E. A. Discourse as an interactional achievement: some uses of 'uh huh' and other things that come between sentences. In TANNEN, D. (org.). Analysing discourse: text and talk. Washington: Georgetown University Press, 1981, p.71-93.

. Sequencing in conversational openings. In GUMPERZ, J.J.;

HYMES, D. (Ed.). Directions in sociolinguistics. New York: Holt, Rinehart e Winston, 1972, p.346-380.

SCHIFFRIN, D. Discourse markers. Cambridge: Cambridge University Press, 1987.

SEARLE, J.R. (1969) Os actos de fala: um ensaio de filosofia da linguagem. Coimbra: Almedina, 1981.

SELINKER, L. (1972) La interlengua. Trad. Marcelino Marcos.In: LICERAS, J. (Org.) La adquisición de las lenguas extranjeras. Madrid: Visor, 1991. Traduzido do original SELINKER, L. Interlanguage, Iral, vol. X, 3, p. 209-231, 1972. 
SERRANI-INFANTE, S. Formações discursivas e processos identificatórios na aquisição de línguas. In: Delta vol.13, no. 01, p.63-81, 1997.

SILVA, G. M. de O.; MACEDO, A. T. de. O status informacional dos marcadores do discurso. Versão preliminar apresentada no XXXIII Seminário do GEL, Campinas, 1987.

SKINNER, B.F. Verbal behavior. New York: Appleton-Century-Crofts, 1957.

SONSOLES, F. Los contenidos estratégicos. In: SÁNCHEZ LOBATO, J.E.; SANTOS GARGALLO, I. Vademécum para la formación de profesores. Enseñar Español como lengua(L2)/lengua extranjera (LE). Madrid: SGEL, 2004, p. 853-876.

STUBBS, M. (1983) Análisis del discurso. Versão espanhola de Celina González, Madrid: Alianza Psicología,1987.

TANNEN, D. Repetition and variation as spontaneos formulaicity in conversation. Washington: Gergetown University, 1985.

TRUJILLO-SÁEZ, F. Objetivos en la enseñanza de lenguas extranjeras: de la competencia lingüística a la competencia intercultural. Disponível em $<$ http://www.ugr.es/ ftsaez/objetivos.pdf> Citado em 2001.

URBANO, H. Marcadores Conversacionais. In: PRETI, D. (Org.) Textos orais, São Paulo: Humanitas; Ed. FFLCH, 1996. . Marcadores Conversacionais. In PRETI, D. (Org.) Análise de textos orais. São Paulo: Ed. da FFLCH/USP, 1993.

VAN DIJK, T. Texto y Contexto. Semántica y pragmática del discurso. Trad. Juan Domingo Moyano. 6a . ed.. Madrid: Cátedra, 1998.

VEZ-JEREMÍAS, J.M. Aportaciones de la lingüística. In: SÁNCHEZ LOBATO, J.; Santos Gargallo, I. Vademécum para la formación de profesores: Enseñar Español como lengua (L2)/lengua extranjera (LE). Madrid: SGEL, 2004, p.127-144.

VYGOTSKY, L.S. Linguagem, desenvolvimento e aprendizagem. São Paulo: Ícone/Edusp, 1988.

YNDURÁIN, F. Sobre el lenguaje coloquial. In: Español actual 3, 2-3, 1964. . Más sobre lenguaje coloquial. In: Español actual 6, 3-4, 1965.

YULE, G. (1985) The study of language. 2a. edição, 10a. reimpr.. Cambridge: Cambridge Univesity Press, 2004.

WATZLAWICK, P., BEAVIN, J.H. ; JACKSON, D. Pragmática da comunicação humana: um estudo dos padrões, patologias e paradoxos da interação. Trad. Álvaro Cabral. São Paulo: Cultrix, 1998. 
WAXMAN, S.R. (2006) Tudo tinha um nome e de cada nome nascia um novo pensamento: vínculos entre aprendizagem de palavras e organização conceptual no início da aquisição da linguagem. In: CORRÊA, L.M.S. (Org.) Aquisição da linguagem e problemas do desenvolvimento lingüístico. Rio de Janeiro: Ed. PUC/Rio, São Paulo: Loyola, 2006, p. 129-173.

WEINRICH, U.; LABOV, W.; HERZOG, M.I. (1968) Fundamentos empíricos para uma teoria da Mudança Lingüística. São Paulo: Parábola, 2006. Tradução de Marcos Bagno do original: LEHMAN, W.P. e MALKIEL, Y. Empirical Foundations for a Theory of Language Change. In: Directions for Historical Linguistics: A Symposium. Austin, London: University of Texas, 1968, p. 95-199.

WEINREICH, U. Languages in contact. The Hague-Paris: Mouton, 1953. 
ANEXOS 


\section{ANEXO 1}

\section{Transcrição RB.37.B.1 - Projeto Val.Es.Co.}

1 B: qué cuándo ireis 1 pueblo por fin?

2 A: al pueblo? (a ver) mañana...sábado... pero cómo quiés decir

3 de vacaciones?

4 C: $\quad$ (ay!)

5 B: sí de vacaciones

6 A: en agosto

7 B: qué tu marido las tiene en agosto? no?

8 A: lo han hecho fijo a mi marido

9 B: aayy! qué alegría! por qué no me lo has dicho?

$10 \mathrm{~A}$

((risas))

11 B: fíjate el otro día comentándolo eh? oye pues estará contento el hombre no?

12 A: contento ( ) sí

14 B: vaya tela!

15 C: oye los numeritos del viaje?

16 A: el cero certo tres (salió)

17 C: que cuál tenemos? es que yo no los veo

18 A: el doscientos yo el doscientos setenta y cinco... setenta y seis y

19 setenta y siete

20 B: ay sí! nosotros teníamos e::1

21 A: (risas)... le ha salido a la mujer del presidente

22 C: aayy! enchufe enchufe enchufe enchufe

23 B: (risas)

24 C: seguro

25 A: eso parece... e::es que a mi marido lo han hecho fijo

26 B: en la fábrica

27 C: síii? qué bi::e::n!

28 A: antes de ayer se lo dijeron

29 C: demasiado bien pero ( )

30 A: ay! esto/estoy muy contenta

31 C: que:: claro se le acababa el contrato esa semana

32 A: a setiembre se le acababa la primera semana

33 B:

34 A: no bastante

35 C: oye pues está bé eh? qué tranquila eh?

Reprodução de um segmento de uma conversação coloquial periférica em espanhol peninsular (BRIZ-GÓMEZ e GRUPO VAL.ES.CO, 2002, p. 224). Critérios adaptados aos do Projeto NURC/SP. 


\section{ANEXO 2}

\section{Transcrição Inquérito 360 - Projeto NURC/SP}

1 L1 ... (uma) de no::ve ... e a outra de seis...

2 Doc. a senhora... procurou dar espaço de tempo entre um e outro...

3 L2 aconteceram ou foram

$\begin{array}{llll}4 & \text { Doc } & & {[} \\ 5 & \text { L2 } & \text { programados } & \text { aconte/... }\end{array}$

6 Doc (isso)... faz favor ( )

$7 \mathrm{~L} 1 \mathrm{a} \mathrm{p} / \mathrm{a} \mathrm{p} /$ é... a programação... havia sido

8 planejada... mas não deu certo ((risos))

9 L2 filhos da pílula não? ((risos))

10 L1 não... ((risos))

11 L2 nem da tabela? ((risos))

12 L1 não justamente porque a tabela não:: não deu certo é que:: ((risos))

13 vieram ao acaso

14 L2 ahn ahn

15 L1 e:: nós havíamos programado NOve ou dez filhos... não é?

18 L2 a sua família é grande?

19 L1 nós somos:: seis filhos

20 L2 e a do marido?

21 L1 e a do marido... eram doze agora são onze...

22 L2 ahn ahn

23 L1 quer dizer somos de famílias GRANdes e::... então ach/ acho que::

24 dado esse fator nos acostumamos a::muita gente

25 L2 ahn ahn

26 L1 e::

27 L2 e daí o entusiasmo para Nove filhos...

28 L1 exatamente nove ou dez...

$29 \quad$ L2 ( )

30 L1 é e:: mas... depois diante das dificuldades de conseguir quem me

31 ajudasse... nó::s paramos no sexto filho...

32 L2 ahn ahn

33 L1 não é?... e... estamos muito contentes e...

34 L2 e dão muito trabalho tem esses esses problemas de juventude

35 esses negócios ( ) (não está muito na idade né?

Reprodução de um segmento de um diálogo entre dois informantes. (CASTILHO E PRETI, 1986, p. 136). 


\begin{abstract}
ANEXO 3
Transcrição Fita 2B do corpus desta pesquisa. Diálogo entre dois informantes. Interlíngua de aprendizes de espanhol
\end{abstract}

1. A: bien... ((risos)) creo que:.... no soy a favor... de la infidelidad... porque:....

2. creo que las personas tienen que ser eh...fieles... a los otros...

3. B: sus compañeros sí

4. A: marido... esposa...

5. B: es es un casamiento de diez años... tiene que tener un poco más de censo... es muy tiempo porque:: tienes un hijo...

6. A: no puedes simplemente salir con otro hombre (risos)

7. B: (ainda) más siendo casada... ( )

8. A: es inmoral...

9. B: es una cosa que yo:: no queRĺa... a mi familia... (quiere hablar más alguna cosa)

10. A: en mi opinión yo no::... no:: iría hacer eso... y tú

11. B: a pesar/ a pesar que:: la... la situación es... es:: solo de la traición... no tienes otra situación... otras:.::

12. Doc.: ay... no sé

13. A: una violencia... del marido...

14. Doc. quizá... quizá...

15. B: así una violencia del marido... una otra traición...

16. A: debe haber algún motivo.

17. B: alguna cosa

18. Doc.: vosotros traicionaríais?

19. B: así ... si yo tuvi/ si estuviese casado (en absoluto) no

20. A: yo también no...

21. Doc.: y si no estuviesen casados?

22. B: depende:: mucho de la situación...

23. A: si es una... una novia... no sé. .. creo que no... no

24. B: si estivermos somente namorando...

25. B: ((risos)) podería sí.. mas casado... es una cosa más... de.: religión... 
26. $\mathrm{y}:$ : una cosa un poquinho más serio... pero... (tá bien)

27. A: pienso:...... pienso lo mismo...

28. B: ( ) muy pequeño... muy pequeño

29. A: sí

30. Doc.: y si estuvieran en un país donde todo fuera permitido... no

31. existieran reglas sociales... incluso traicionar fuera permitido...

32. traicionarían?

33. A: ah... entonces... ((risos)) yo... ((risos)) si es permitido... está:... na ley...

34. creo que sí

35. B: a pesar que nosotros crecemos:. en la sociedad ya con... 


\section{ANEXO 4}

FICHA SOCIOLINGÜÍSTICA

Nome completo:

Endereço:

Bairro: Cidade: Estado:

Telefone para contato:

Email:

Data de nascimento: I

Natural de:

Nível de instrução:

Profissão:

Se estudante, curso e período:

Nível de aprendizagem de espanhol:

Com relação à aprendizagem da língua espanhola, especifique:

a O local onde fez o

Básico 1:

Básico 2:

Intermediário 1:

Intermediário 2:

Avançado:

A nacionalidade de seu professor no:

Básico 1:

Básico 2:

Intermediário 1:

Intermediário 2:

Avançado: 


\section{ANEXO 5}

Documento: Fita 1A (Básico - Lado A)

Local: São Paulo

Data: 25 de outubro de 2005

Diálogo entre duas alunas do curso de Letras - espanhol

Documentador: Observador e promotor da conversação

Assunto: Infidelidade

Nível: Básico II

Faixa etária: 20 a 24 anos

1A. la infidelidad para yo es muy (complexa)((ruidos externos)) pero... las 2personas ... hoy en día ... son ... muy... (risos) son muy ... infiel a su cargo... 3a...((ruidos externos))... a sus compañeros... a sus amigos... entre otras cosas

4B. hay pesquisas sobre la infidelidad...y... piensan que... el hombre es que 5trae la mujer... pero:: la última que salió hoy es que:: la mujer que trae... más el 6hombre...

7Doc. ¿vosotras traicionaríais?

8A. sí... yo ya traí... mi no::vio varias veces... pero que ho::je... yo creo que... 9no... no faria más... es una sensación... muy complicada... después que... 10que... ocorre o caso (de terminar)... es una cosa que... que yo... repensé:.... 11y que no:.... me fez BEm...

12B. la infidelidad nunca hace bien ((ruidos externos)) a las personas... ((ruidos 13externos))

$14 \mathrm{~A}$.

$$
\text { y también... }
$$

15B. nunca hace bien a las personas... eh... principalmente:: aquellas que:: 16traen su:: compañero su compañera... y:: se queda cualquier peso en la 17 mente... 
18A. (risos) CLAro... es mi caso con mi novio (risos)

19A. ((dirigindo-se à documentadota) ¿qué más chica?

20Doc. ¿qué piensan a respecto de la infidelidad?

21A. la infidelidad es algo... muy...

22B. feo...

$23 \mathrm{~A}$. muy mal... triste... pero yo ya... ya cometí

24infidelidad...

25B. ¿ya fuiste traída?

26A. sí::... CLAro

27B. y cuál es el sentimiento?

28A. es un sentimiento...muy ...¿ ¿TRISte?

29B. por eso no:: quiere... más trair...

30A. no:: no:: yo ya desisTl... de esas cosas... de me ... de...de relacionar con $31 \ldots$ con dos personas

32B. al mismo tiempo

[

33A. al mismo tiempo... es algo que:: confunde toda la cabeza

34B. mismo porque no... podemos tener dos personas al mismo tiempo...

35A. CLAro...

36B. no podemos tener dos hombres ...

37Doc. $\quad$ pero sl pudieras tenerlos... ¿los tendrías? 
39Doc. ¿tendrías dos hombres al mismo tiempo? mismo se estuvieras en un 40país donde ... por ejemplo... si estuvieras en un país donde todo fuera 41 permitido ... donde no existen reglas sociales y traicionar fuera permitido ... 42 ¿traicionarían?

43A. sí... claro... yo aproveitaria (risos) todas las oportunidades que... que a mí 44fuese puesta...

45B. no yo dejaría ( ) (risos)

46Doc. qué piensas entonces de mi amiga...por ella estar traicionando y tener un hijo de diez años ... qué piensas...

47A. es más complicado... porque... (su) ya... (fez) se comprometeu ahm con 48su familia... eh... es un caso...

49B.

mismo/

[

$50 \mathrm{~A}$.

más complicado

51B. mismo porque todo acto tiene una consecuencia...y:: no ahora... pero 52delante ella... va eh... ver la consecuencia de su traición

53A.claro

54Doc. y el hijo... si el hijo supiera que la madre le traiciona al padre... qué 55 pasaría con el hijo... en la cabeza del hijo ... qué pasa ... qué piensan que se 56le pasa

57B. una frustración... decepción... porque para el... la madre es la mejor 58 mujer...es perfecta....

59A.eXEMplo ... no::: 
60A.uhm uhm un ejemplo

61A.ejemplo... sí claro... y:.: también es responsable pela educación de su hijo...

62Doc. y el padre... si el padre supiera que la madre lo traiciona... o mejor... 63que la pareja (né)... que la mujer de él ... lo traiciona ...qué piensan que:: 64que haría él

65B. ma::tar ella... (risos)

66A. en muchos casos sí... (risos)

67B.

matar ella $0 . .$.

$68 \mathrm{~A}$.

(temos que...)

69B. es difícil ... pero:: existen personas que perdonan ... (risos) que aman 70tanto...(tiene cosas así)/

71A. sí ... otras que... brigam ... agridem...

72B. pelean

73A. sí... pelean...

74B. pero creo que... no sé... porque no lo conozco... no sé... si yo:: lo 75 conocesse podía decir... no sé si va a perdonar... no sé si.:. va a matar...

$76 \mathrm{~A}$. tantos/ mas muchos 77casos de tragedia con/ envolvendo:: infidelidad... cuando... ma/ cuando 78cuando...

79B. mismo lo que más/ 
$80 \mathrm{~A}$.

el hombre descobre que su mujer o trae... trae...

81 (la lección)...

82Doc. conocen casos eh de amigos de de vosotras que que ya traicionaron ...

83B. sí ... siempre... todas se dieron MAL

84A: sí?

85Doc: conoces un caso que podrías contarnos?

86B: mi vecina... ella era casada... ella... tiene tres hijos y:: ella... trajes traje su

87hermana... de otro estado y su herMAna... pasó a vivir con ella...y:: la 88hermana de ella pasó a tener un caso con... el marido de ella...descubrió y el 89 marido se FUe... dejando ella y sus hijos... solos

90A: qué triste no?

91Doc.: tú conoces algún caso?

92A: no... yo no conozco... 
Documento: Fita 1B (Básico - Lado B)

Local: São Paulo

Data: 23 de agosto de 2005

Diálogo entre duas alunas do curso de Letras - espanhol

Documentador: Observador e promotor da conversação

Assunto: Infidelidade

Nível: Básico II

Faixa Etária: 18 a 21 anos

1A: BUEno... creo que:....... si ella está::... eh...si ella es infiel con con el 2 marido... con el esposo...es porque no... no... ahm...eh... es porque no está 3más enamorada de él...(risos)

4B: sí... no está contenta

5A: sí... entonces...la infidelidad... ahm... cuando cuando ocurre... sirve para:: 6para destruir lo::s los casamientos y todo más creo que:: 7

8B:

pero hay muchas

9personas que siguen juntas mismo después de la infidelidad... mismo después 10 que uno cuenta al otro

11A: sí pero creo que:: ahm... nadie es obligado a quedarse con nadie... 12entonces no no sé porqué ocurre... y tal... PEro hay algunas personas que::.... 13que le gusta... que les gusta ser infieles...y todo más... pero a Mì no me 14 gusta...(risos)

15B: y hay personas que aCEptan normalmente como se no tuviese tuvieres $160 c u r r i d o$ nada ...

17A: nosotras tenemos un (risos) ejemplo

18

19B:

[ [

20persona sabe lo que es mejor pra/para si mismo... eh... creo que es una 21 opinióN persoNAL...es de CAda persona... CAda persona piensa:: de 22distin::tas maneras... entonces:.... no sé... pero mi... eh... Ml opinión... a 23ese resPECto es que... creo que no:: no:: es neceSA::rio estar con ALguien y 24quedarse con otra persona al mismo tiempo... creo que:....que:.... 
25A: sí si está con alguien pero

26

27B: si no esta bien...

$28 \quad[$

29A:uhm...uhm...

30B: es mejor que...

31A: (ir con el otro)

32B: sí

33Doc.: vosotras traicionaríais?

34A: bueno:: (rizos)... creo que no:.... por eJEMplo... si yo estoy con alguien y... $35 y . .$. me gusta esa persona... si la amo... y todo más... creo que no no tengo 36ganas:: creo que de/ de/ eh... va a depender de cada relación que tengas con 37alguien... por ejemplo... a veces estás con alguien y y la persona no... no... y 38el relacionamien/ de/ re/ relacionamiento no está muy... muy bien... no es 39 muy...

40B: y hay personas que también no conSlguen terminar un relacionamiento y 41 continúan con ello... con él y ... sigue sen/ siendo infiel...infiel...

42Doc.: traicionarías A.?

43A: yo creo que no... yo eh... ya ya se pasó conmigo de estar con alguien sin 44 sin ser compromeTIda formalMENte... estar saliendo solamente con alguien... 45saliendo no... estar... eh... a veces con alguien... a VEces... saliendo a 46VEces... y... y... de acabar me me me interesando por otra perso::na y tal 47cosa... pero... la/ eh... MI opinión ES... si estás con alguien... y y:: si la ama y 48todo más... no... creo que no es posible... creo que la...trai... eh... 49

50B:

posible es pero

51 no hay la necesidad

52

53A: $\quad$ ah sí creo que la traición ocurre... la traición pasa porque:: no está 54 contenta con algo o con alguien... que esTÉS... por eso que no no hay cómo 55cómo dar una... cómo hablar... yo NUNca voy a... así... eh/ creo así... eh... 56 creo que:: que yo::... por mí opinión ... creo que:: no:: no me gusta... 57B: yo creo que:: yo:: haría se:: estuvie::ra (peleando) con alguien... o... 58A: muy triste 
60B:

61

62A: con alguna cosa

63B: con algo que ocurrió:: y... no me gustó::... y:: entonces:: con... (raiva)

64A: con rabia

65B: con rabia... haría... pero creo que no...

66A: yo tampoco...

67Doc.: entonces mi amiga está equivocada por traicionar... no es correcto y 68tampoco...

69B: NO...

\section{$70 \quad[$}

71A: creo que esta persona

72

73B: $\quad$ hay que ver lo que ocurre con ella...

74

75A:

$$
\text { creo }
$$

76

77B:

nosotros no podemos hablar de ella

78sin conocerla...y:.::

79A: pero pero lo que pasa... lo que da... lo que... así... la la la intención que... $80 q u e$ que ella está pasando... es que... ella está casada con un hombre que no 81 no le gusta... y está con él solamente por...por el hijo... sí... y:: y isto y esto $820 c u r r e$ con muchas personas... de estar con alguien solamente por el/ por sus 83hijos o por su casa... o por su dinero... o por su vida...eh... por su vida ahm... 84 personal... porque no tiene dinero para... para ser/ quedar

85

86B:

\section{independiente}

87

88A:

independiente y todo más...

89 creo que ella está equivocada... creo que... creo que LA persona antes de... 90de:.... de:: quedarse con alguien o CUando está con alguien... tiene que 91 hacer su propia independencia... no tiene que quedar...eh... con alguien por 
92el hijo o por el dinero... creo que cada un tiene que tener su vida propia... el 93hijo VA a sufrir ...sí si los padres se separan... pero:.... y aHí:....

94B: no hay otra manera creo que no hay otra manera 95A: sí...

96Doc. y si estuvieran en un país donde::: no existieran reglas sociales y todo 97fuera permitido... incluso traicionar fuera permitido... traicionarían...

98B: no... no... porque creo que no no es porque no hay... ley... que:: yo voy 99hacer si... yo... creo que no:: es bueno... que no:: necesito

100A: yo CREo que:: para mí ... no es porque la regla dice que es/no puedes 101B: que es feo

102A: sí no no puedes quedarse con dos personas al mismo tiempo:.....todo 103más... creo que... para Mí no es interesante... si estoy con alguien y me 104GUSta esta persona de VERdad... no tengo (ganas )... ahora... si estoy con 105alguien... a veces... de vez en cuando y:: y no:: sabe... y no no y no estoy 106muy... eh...muy

107

108B: ( )

109A: (risos) sentimental... con él... ahí:: ahí sí... pero no creo que esto es una 110 traición... ya hice is/eso pero... pero no creo que es una traición...

112Doc. conocen alguna historia de ese tipo...

113B: sí

114Doc. de alguien que::

115

116A: (risos) un monte

117

118Doc. $\quad$ por ejemplo... (risos) se puede escuchar una...

119B: ah...nosotras saBEmos....

120A: eh... a ver... de amigas qué son casadas...

121Doc. que traicionaron...

122A: yo tengo una amiga que:: es casada... hace muchos años... hace más o 123meno Velnte años...y:: tiene dos hijas... y no...así ... no le gusta vivir con su 124esposo... pero a él le gusta vivir con ella... pero a ella NO y:: y:: no... y:: así:: 125se quedaba con él:: cuidando de la casa:.... de las hijas:.... no trabajaba 126porque él no dejaba... no estudió porque él no dejó... y ahí:: se::/ un día 
127ella... empezó a a a con una (traición) y todo más...y se quedó una 128situación... eh... eh... la situación se quedó muy:: muy:: tensa... porque:..... 129él empezó a a:: decir que iba a matarla... y todo más...(risos)... es di/ creo $130 q u e$ es difícil... pero ella...que pasó con ella... se quedó tantos años se 131dedicando a a a la vida de casada... a sus hijas... al marido y se olvidó de 132ella...de sí misma ...y:: cuando ahm... abrió los ojos... se despertó... ya era 133un poquito tarde y todo más... pero hoy hoy en día ya está estudiando 134...quiere trabajar... la situación que vivía con su marido la cansó... entonces 135hoy quiere mudar de vida... pero es difícil... está (una/si) está muy difícil 136para ella conseguir...

137B: ahm... tiene el tío de mi novio:: era casado... ellos tienen dos hijos... una 138tiene diecisiete años y el otro doce más o menos y él... ellos... eh...se 139daban bien... y.:.: eran mismo... eh... y mismo así... eh... él se encontraba... 140eh... con una mujer que vive pocas calles acima y::: mesmo mismo ellos 141siendo felices él... se quedaba... él trabajaba... él es eh es policía... él 142trabajaba y:: por la no::che él salía con ella mismo:: se/así... mismo 143gustando él salía... y ahora ellos...eh... se separaran y él no sale más con 144ninguna de las dos (risos)

145Doc. y si tuvieran que decir algo a mi amiga...una especie de consejo ...qué 146 sé yo... que le dirían...

147A: diría que:: tendría o que tendrá... que hacer su vida propia... que viva su 148vida propia...no pensar tanto en el hijo... pensar en ella en primero 149lugar...después en el hijo...

150

151B: $\quad$ pero no sabes porque hace eso...

152

153A:

porque::.....

154

155B:

ella hace eso...

156A: ah sí claro... por ejemplo... si si la situación... si todo esto pasa por el 157hijo... un ejemplo... ella eh tiene que pensar que que el hijo va a crecer.. va 158 a tener su vida propia... entonces... ella también tiene que tener... y 159después/si si no tiene ahora... después podrá ser tarde... entonces... yo 
160pienso que ella tiene que hacer su vida que trabajar... que estudiar... que 161hacer su independencia... y quedarse con el otro hombre... o con cualquier 1620 tro que sea...no dar mucha importancia al marido... ya:: ya que no le 163gusta...

164B: yo creo que:: ella tiene que::: decidir eh... lo que quiere de su vida:: y:: ver 165 con quién quiere hacer su vida... con un o con otro.... 
Documento: Fita 2A (Básico - Lado A)

Local: São Paulo

Data: 19 de agosto de 2005

Diálogo entre dois alunos (homem/mulher) do curso de Letras - espanhol

Documentador: Observador e promotor da conversação

Assunto: Infidelidade

Nível: Básico II

Faixa etária: 21 a 23 anos

1A: (risos) empiezas

2B: yo empezar... sobre la infidelidad...no sé... eh... yo creo que:: ella no le 3gusta de su ... no le gusta más de su marido:.... pues... si no:.... no sería 4infiel... no sé...qué decir sobre la infidelidad

5A: (risos) yo tampoco...y yo creo que si ella está traindo... es porque:: no le 6 gusta más elle PEro::.: que le resta es:: hablar sobre lo que está... ocuRRIEndo 7para... solucionar né:: el el equívoco... (risos)

8B: y qué crees que ella debe hacer

9A: yo:: creo que:: ella... debe HAblar con él ... sobre él...

10B: el quién

11A: sobre él/ su (rizos) sobre él su...(risos)

12B: su maRIdo

13A: sí::

14B: y contar la verdad

15A: sí:.:: contar la verdad... es lo correcto...

16B: no tiene... no tienes MIEdo

17A: ah... yo creo que hay miedo pero.:. es necesario contar la verdad... né... 18 yo creo...

19B: sí::: la verdad acima de todo...

20A: uhm uhm...

21B: pero:...... pienso ser muy diFÍcil llegar al marido y... decir tu/ todo... toda la 22verdad que está saliendo con el otro... y con quién va a quedar el hijo...

23A: sí... es un problema también... yo creo que ella no necesita decir toda la 24 verdad... eh... debe solamente decir que está::... que no:.... que no tiene más 25interés por él... eh... después... (risos) 
26B: pedir la separación...

27A: pedir la separación...

28B: sí:: yo creo también que sea más Fácil... pedir la separación y después:: 29aparecer con otro novio... (risos)

30A: sí... es más fácil... hasta:: eh... porque (rizos) la vida ES así...né

31B: (no sé)... ahm... a mí creo que no llegaría eh... este punto... antes de.: 32envolverse con otra persona... ya tería hablado... para mi:: esposa y... teri/ 33ya:: tendríamos nos hablado...

34A: yo también agiría de la misma forma...

35B: no acredito en la infidelidad...

36Doc.: vosotros traicionaríais?

37A: empiezas tú...(risos)

38B: ah yo... (risos) no:.... creo que no... nunca ocurrió:: ahm... este:.:. tipo de 39cosa::: creo/como lo dice antes....creo que no llegaría a este punto....

40A: yo también no... pero creo que las cosas... eh... se van ocurriendo...(risos) 41 (de los) momentos...né

42B: los momentos...

43A: sí...pero:: también no... ((risos))

44B: no llegaría...

45A: no (risos)

46B: no sé... no sé... solamente quien vive...

47A: sí...

48B: una cosa...

$$
\text { [ }
$$

49A: solamente quien vive...(risos)

50B: una cosa de esa puede decir...

51A: sí...

52Doc.: si estuvieran en un país donde todo fuera permitido... donde no 53existieran reglas sociales... incluso donde traicionar fuera 54permitido...traicionarían?

55A: uhm... depende...solamente en no... en un país así::: para saber... pe::ro 56 yo creo que no... 
57B: yo no no traicionaría porque:: a mí no me gustaría que hiciesen 58 esto...entonces... yo también no hago... no no hago este tipo de cosa... 59 mismo que... (fuese en broma) o ( ) (risos)

60Doc.: y el hijo... que piensan del hijo...si el hijo sabe lo que esta pasando 61 eh... que su madre esta traicionando al a al padre... qué pasará en la cabeza 62del hijo

63A: si es una:: difícil:: né... difícil trabajar con hijo...por/pues cuando son 64peQUEños...né... ahm... pasan muchas cosas en sus cabezas...es muy... es 65muy:: delicado es/ el problema né... pero es cierto dexa dejar bien clara la 66situación para que... el tico también pueda:: solucionar el problema junto 67 con... la madre cum:: el padre...

68B: ah... no sé que se pasa... si for un tico:.:. muy:....... muy.......

69A: ( )

70B: no::.: ciumento?

71A: ciumento...

72B: ciumento... eh... a él no le va a gustar nada...

73A: sí::

74B: la la separación o que la madre estea con otra otra persona...

75A: es bien complicado... pues uhm... cuando... yo trabajaba con eso tipo de:: 76 situación el tico queda uhm con un problema:: queda con un problema muy 77difícil... hasta porque está creciendo né... eh... entonces eh... queda con 78problemas psicológicos en relación con los otros/ con los demás... es muy 79complicado::

80Doc. a ver... uhm... y si:.:.: ya conocieron algún acontecimiento de eso tipo... 81de algún amigo... de alguien que le traicionó al compañero?

82A: sí:: pero... tiene un caso que:: que yo he conocido... quedó muy bien no:: 83no tuve muy:: muy problemas

84B: yo conozco un caso de:: a a mí me parece una una telenovela (rizos) 85mexicana...si...porque es verdad... cuando yo:: he Oĺdo la persona 86contando... eh... me quedé:: con la boca abierta ((risos)) hasta (mis pies) 87 (risos)es la madre de un amigo mío...

88A: $\quad$ uhm 
89B:

y:: y ella...estaba enamorada... por:: el padre de él...

90entonces:: los dos estaban novios e iban a casarse...cuando llegó el el 91 hermano de:: del novio... né y ella se enamoró por el hermano... cuando ella 92tentó...intentó romper su... su... relación...eh... su novio dice que ía 93matarse...

94A:

nossa::

[

95B: entonces... ella acabó se casando con un hombre que no:: que ella no 96gustaba más...pero:.... pero el enamorado ( ) el hermano de él... y:: este $97 a m o r . .$. queda hasta hoy...veinte treinta años después y::: ellos hacen planos 98de quedarse juntos después que el hermano murrier

99A:

murrier (risos)

101B: sí:: es verdad... porque yo eh yo me quedé:: asustado...né porque... 102pensaba que solamente:: en la GLObo... se veía casos así::

103A: sí.:.: pero... bom... en la vida

104B: (risos)

105Doc. crees que en la vida eso ocurre demasiadas cosas como...

106A: sí:: ocurre... pero...eh... ocurre más con los hombres do que con las 107mujeres no:: (risos)

108B: no lo sé...creo que no... creo que no... creo que no...

\section{[}

109A: yo creo que los hombres son más infieles que las mujeres... pero:: (risos) 110B: no... no:: hay tantas personas infieles... tanto hombres cuanto mujeres... 111ahm...una cosa es verdad... los hombres cuando hacen la traición... eh... 112ellos acaban mostrando...

113A: uhm uhm

114B: a todos... las mujeres no... las mujeres::

115A:

sí:: las mujeres son más

116discretas...

117B: ocultas:: 
118A: sí:: ocultas...pero el... es que cuando eso ocurre con el hombre...es más 119común...né... la sociedad admite mas:: como un acto... un acto:: normal... 120né:: pero es pero cuando es con una mujer ya (admite) mas como una sin 121 vergüenza y otras cosas

122B: no lo sé:: creo que no:: porque... si las mujeres no ocultasen tanto podrían 123mostrar... que también existen de facto y podría sí:: legitimarlos

124Doc. :entonces... mi amiga es vista como una sin vergüenza (risos)

125A: por por la sociedad

126Doc:: $\quad$ por la sociedad

127A: $\quad$ sí... la sociedad legitima la mujer de esta forma

128B: algunas personas

129A: sí::

130B: preconceituosas... que no:.... la conocen no saben qué se pasa dentro de 131la casa de ella... dentro de la vida...del cotidiano... cuando una persona 132eh... hace una traición... yo creo que:: la relación eh... se acabó mucho 133tiempo... entonces... será que es una traición de la

134A: sí:: si estuvieran juntas:: yo creo que es una traición..

135B: juntos cómo... qué es estar junto... para ti::

136A: papel (risos) legítimo (risos)

137B: so solo el papel

138A: sí::

139B: solo el papel es estar junto::

140A: sí:: pero si no están juntos son::

[

141B: y el sentimiento:: y el sentimiento::

142A:

pero la ley la ley juzga el que es un error estar junto y hacer

143 este tipo de cosa ... pero el sentimiento que dice más alto (no)

144B: yo creo que sí

145A: sí:: yo también (risos)

146Doc: yo no puede estar junto sin un papel?

147A: no:: ... 
148B: sí:..... juntos con fe... casados son...(risos)

149A: boa::

150B: (risos) o no::

151A: sí (risos)

152B: una pareja de novios... sin estar casados... están juntos o no 153A: esTÁN juntos::

154Doc.: diez sufridos minutos... muchas gracias 


\section{Documento: Fita 2B}

\section{Local: São Paulo}

Data: 24 de agosto de 2005

Diálogo entre dois alunos do Curso de Letras-Espanhol

Documentador: Observador e promotor da conversação

\section{Assunto: Infidelidade}

\section{Nível:Básico 1}

1A: bien... (risos) creo que:.... no soy a favor... de la infidelidad... porque:.... creo 2que las personas tienen que ser eh...fieles... a los otros...

3B: sus compañeros sí

4A: marido... esposa...

5B: es es un casamiento de diez años... tiene que tener un poco más de censo... 6es muy tiempo porque:: tienes un hijo...

7A: no puedes simplemente salir con otro hombre (risos)

8B: (ainda) más siendo casada... ( )

9A: es inmoral...

10B: es una cosa que yo:: no queRĺa... a mi familia... (quiere hablar más alguna $11 \cos a)$

12A: en mi opinión yo no:.... no:: iría hacer eso... y tú

13B: a pesar/ a pesar que:: la... la situación es... es:: solo de la traición... no 14 tienes otra situación... otras:.:.

15Doc.: ay... no sé

16A: una violencia... del marido (silêncio)

17Doc. quizá... quizá...

18B: así una violencia del marido... una otra traición...

19A: debe haber algún motivo...

20B: alguna cosa...

21Doc.: vosotros traicionaríais?

22B: así ... si yo tuvi/ si estuviese casado (en absoluto) no

23A: yo también no...

24Doc.: y si no estuviesen casados?

25B: depende:: mucho de la situación...

26A: si es una... una novia... no sé. .. creo que NO... no 
27B: si estivermos... somente... namorando... (risos) podería sí.. mas casado es 28una cosa más... de:: religión...y:: una cosa muy más seria... pero... (tá bien) 29A: pienso:...... pienso lo mismo...

30B: ( ) muy pequeño... muy pequeño (risos)

31A: sí

32Doc.: y si estuvieran en un país donde todo fuera permitido... no existieran 33reglas sociales... incluso traicionar fuera permitido... traicionarían?

34A: ah... entonces... (risos) yo... (risos) si es permitido... está:.: na ley... creo 35que sí

36B: a pesar que no/no/nosotros crecemos:: en la sociedad ya con...

37A: leyes

38B: leyes sí... es una cosa que ya está::

39A: no podemos imaginar...

40B: nosotros... una cosa que ya EStá con nosotros

[

41A: $\quad$ como sería

42B: mismo que:: que yo esté en otro país... creo que:.... me sentiría como se 43estívese errado

44A: estamos acostumbrados a ser así (silêncio) (risos)

45B: (otro asunto)

46Doc.: y si estuvieran en lugar del padre y supieran que que que la pareja 47traiciona... qué harían?

48B: yo:....eh... como... había decido un co/casamiento de diez años ... una 49hija de nueve años... YO... no me sentiría muy bien me sentiría muy mal...( 50) me sentiría muy mal

51A: y yo como padre... no permitiría... de eso:: acontecer en una familia... por 52 motivos... de nuevo moRAles... es contra mi:.... eh...contra todas as... 53contra todas mis:: opiniones...

54B: MISmo que venga... que VENga a acontecer... mismo que ven::ga a 55 acontecer... se puede... acontecer...es... (algo) terrible... la forma más 56 simples posible... (sei lá que piensa)

57A: igualmente....algo más? (risos)

58Doc. y si fuera tu amigo Eliabe que estuviera pasando por todo eso? 
59B: NO conmigo NO (risos) no voy hacer esto (risos)

60Doc.: pero y si... con todo respecto...y si lo hiciese... así... qué les 61 aconsejaría?

62A: YO con... la novia de Eliabe?

63Doc.: NO:: (risos) no tanto pero:.... quizás... no sé...

64B: un amigo... un amigo...

65Doc.: sí...

66B: un amigo...

67A: no hazo e(so)...

68B: yo creo que ( )

69Doc.: pero:: si:: aconteciese?

70A: nunca con amigos...

71Doc. como enemigos....

72A: mis amigos son muy... muy... eh:: especiales para mí...no no no haría 73eso...

74Doc.: qué les diría si con uno de ellos ocurriera algo... parecido?

75A: con alguien que yo conozco?

76Doc.: uhm uhm qué le diría?

77A: ah en ese momento... no:: no sé...

78B: decir algo é é difícil demás...

79A: estaría sin palabras...

80B: SIN palabras (silêncio)

81A: (risos) sin palabras

82B: (es) posible... por eJEMplo

83A:

no estaría... contente...

84B: no MISmo (risos)

85A: NO mismo

86B: no sé si acontecese esto conMlgo... yo acredito que:: ficaria muy mal::

87A: también

88Doc.: contigo o con tu amigo?

89B: con los dos... tanto con la mujer... como con mi amigo...

90Doc.: ah... sí:: uhm uhm... si fueras traicionado por un amigo tujo... 
91A: pero:: eh en mi opinión... más con el amigo... do que con los dos...

92B: con los dos:: con los dos

93A: un poco más con mi amigo (silêncio)

94Doc.: un poco más...((risos))

95B: yo no yo no haceria esto

97A: porque esperaría más...

98B: con los dos yo no haceria esto con los dos

[

99A: más fidelidad de mi amigo do que:: con la novia... es verdad...

100B: yo no hacería con lo ( )

101A: generalmente el amigo es... una perSOna:.... que que usted conoce:: 102hace:: más tiempo... enTONces:.... (risos) no puede

103B: tienes una confianza con con con el aMlgo...sí... de:: hablar muchas 104co::sas... hablar mucha/ a veces até de su mujer con su amigo... usted ve... 105su mujer con su amigo...

106A: porque ciertos amigos son considerados... hermanos...

107B: sí

108A: entonces...son casi co::mo familia...

109Doc.: entonces es más fácil mantener una fidelidad con un amigo do que con 110una... con una (pareja)

111B:

no

112con los dos...con los dos... sí... mas:: como A. dice:: un amigo eh:: es 113 como un hermano...sí... tienes muy contacto

114A: geneRALmente::: una amiga...una novia... es una persona que:: que 115usted no conoce:: hace mucho tiempo... generalmente...

116B: sí... a veces

\section{[}

117A: pero no siempre

118B: (entiendes) tienes amigos ... de años atrás... sí

119A: desde la infancia... 
120B: de la infancia... tienes amigos que... pasan lo tiempo... lo tiempo juntos... 121 no trabajo... na escuela...

122A: que ves todos los días::

133B: mucho más tiempo a veces que con la mujer... con la namorada... 134(silêncio)

135Doc.: y el hijo? qué piensan que pasa en la cabeza de un hijo que tiene 136una::una madre que le traiciona al padre?

137B: ay::: (suspiros)

138A: estaría MUY abalado... MUY triste con la situación... cualquier hijo.... 139B: algunos:: no no::... tal vez no entenderían la situación...

140A: depende de la:: de la edad.... (silêncio) 
Documento: Fita 3A (INTERMEDIÁRIO - Lado A)

Local: São Paulo

Data: $\mathbf{3 0}$ de junho de 2005

Diálogo entre duas alunas do curso de Letras - espanhol

Documentador: Observador e promotor da conversação

Assunto: Infidelidade

Nível: Intermediário I

Faixa etária: 17/18 e 23 anos

1A: es eso yo creo que no me parece bien eh eh. hay que ver con:: la decepción del 2casamiento que la persona no conoce... generalmente é:: el la la pareja si? que se quedó 3 con otra persona que a la verdad a la vez no conocía y:: mucho ( ) la necesidad del 4cariño del amor de las personas siempre actualmente es é:: suPRIda por esta necesidad 5 que que tienen de de:: casarse de quedarse juntos para:: para:: rellenar esa falta y lo que $6 \mathrm{~s} / \mathrm{saBla}$ es esto

7B: uhm uhm

8Doc. eh de verdad pueden trabar una conversación no hace falta que sea la opinión o sea 9mientras A. está hablando tu también puedes hablar en fin ... lo que quiero es una 10conversación como si estuvieran efectivamente hablando entre amigas sobre ese tema 11 no? cómo actuarían si supieran de cosas parecidas?

12B: bueno yo:: así... me pregunto primero:: el motivo porque eh porque una persona va 13a:: ser infiel con su con su marido y esa cosa:: si si:: juró frente al cura que iba a ser... 14iba a ser compaÑEra en la tristeza en la alegría en la salud en la enfermedad siempre y 15 no:: no comprendo si:: si está buscando una felicidad lejos del casamiento alguna cosa 16 no está bien no sé si es... la el compañero la la relación no sé si no hay más amor... 17porque:: bueno creo que si es un caso así si fuera yo... yo eh charlaría con con mi 18marido y no me quedaría con el solo por causa del hijo... para mantener la apariencia si 
19A: y y y las personas ya (no sienten) la necesidad de mantener una relación a causa de 20un hijo y:: lo que (he) ocurre es que (algún) hijo termina por sufrir más do que los do 21 que los los padres

\section{B: porque vive una familia que que no existe no}

23A:

sí

24B:

es una familia solo de apariencia

25A: intentan aun intentan todavía hacer al máximo para mantener la la familia y queda peor...

26B: el niño un día va a a percibir que no está... bien

27A: y no está cierto no (estoy) de acuerdo en esconder la verdad que lo que pasa eh eh 28en la vida de un casal que tiene un hijo al propio hijo... todo debe ser muy claro porque 29cuánto más se esconde escon se esconde cuanto más se deja para después de contar (a) 30lo que es muy importante al crecimiento desarrollo del niño después el descubre y 31queda una crian eh un nino eh uma:: un futuro joven revoltado que empieza a hacer 32más preguntas que (solamente) su propia vida de sus relacciones con las otras personas 33porque yo no tuve... porque yo no tuve el derecho de de llevar una vida como los 34demás si no mis padres no tienen la capacidad de decir la verdad de lo que pasa 35 conmigo porque yo tengo que decir la verdad de lo que pasa a la sociedad... y es muy 36 serio ta (por eso es que) uno puede desde eh se drogarse hasta matarse... es muy serio

37B: piensas entonces que es mejor que la pareja se separe?

38A: es me es más sencillo... es más sencillo... y además que:: 
39B:

el hombre puede

descubrir

también

40A:

un un ser humano es lleno de

41equivocaciones... entonces puede equivocarse (al pasarlo) las parejas las parejas no 42tienen que ser perfectas y esa búsqueda de la perfección es que hace um casamiento eh 43esgotar... la búsqueda de:: de un de una pareja perfecta de una persona perfecta o sus 44actitudes perfectas y (bajas) no dejan que el otro se manifieste con su libertad con sus 45 convicciones

46B: pero piensas que si la mujer se arrepiente de... de lo que hizo el marido debe... perdo perdonar

47A: depiende del marido ((risas))... si es un marido así que es más... eh... menos... 48menos cascarallo yo creo... pero es difícil a causa del carácter caracter del hombre... el 49hombre lleva un carácter muy fuerte

50B: porque puede así también de la mujer eh no de no haber se acabado el amor... pero:: fue apenas um error de la mujer no sé::

51A: pero el los hombres pueden traicionar... las mujeres no pueden traicionar

52B:

ah no

53A: es eso que los hombres piensan... algunos llevan eso yo puedo traicionar pero tú no 54porque tú eres mía estás en mi mano y yo tengo el poder... bajo tú... no es? ((risas))

55entonces... hay...primero que... mantener un pensamiento que... eh la pareja si... ambos 56tienen que que llevar la misma convicción yo te respecto tú vas a respectar a mí 57también sí sí tú (es el que) te equivocas no simplemente puede (cerrar) un 58relacionamiento yo como hombre o como mujer cierra un relacionamiento y continua 59siendo aMlgo:: 
60B: si fuera tú

61A: lloraría mucho (risas)... si fuera yo que que::

62B: el marido

63A: el marido?... primero... yo preguntaría lo que pasó... ha eh eh haber haber ocurrido tener tener?

64B: haber

65A: haber ocurrido la traición... bueno? después ...

66B: y si ella le pidiera perdón?

68A: ay no sé yo creo que:: es mi... como persona que yo soy exigente no? ((risas))

69B: no iba a perdonar?

70A: no... tú ibas? tú perdonarías?

71B: no sé... creo que:: si yo lo:: lo amase mucho mucho mucho... creo que después de MUcha charla...

72A: pero piensas en una cosa eh tu amas demasiado a él sí... pero:.: él te ama demasiado para quedarse así? y si...

73B: claro... te traiciona? te traiciona de nuevo? ah sí

74A: ah! dos traiciones no permites una traición ...

75B: pero depende de:: la de la situación 
76A: como? no entiendo...

77B: sí:: porque:: no sé... a veces la... la mujer no estaba:: no sé estaba carente no sé:: alguna cosa así el marido no le daba atención

$78 \mathrm{~A}:$ y después

79B : la trataba mucho...

80A : y después de la traición

dejó la carencia

81B: no:: no pero:: pero percibió el error que cometió y:: y:: y prometió que no iba a hacer más pero si si hace de NUEvo...

82A:

yo yo soy::

83B:

pueda

[

84A:

yo soy:: una persona que:: que:: el

relato 85 coincide mucho porque yo tengo uma amiga que ya acompañé todo lo que pasó yo fui 86hasta la família charlar con la madre que lloraba en desesperación porque... la chica 87 eras mi eh era mi amiga muy amiga sí... y y eh lo que pasó fue quedo enamorada de 88um hombre casado si... y salía côn él... no llegó a TANto pero... salía con él hasta que 89una profesora la descubrió en um (coche) que era de la escuela habló con una hermana 90que también trabajaba en la escuela como profesora... y y después la hermana fue a 91contar a Madre... cuando la madre supo mi amiga quedo en desesperación... y el ni la 92clase toda sabía lo que se pasaba el problema es que yo era la amiga más cerca de ella 93y ellos fueron hasta... jo... eh eh jota ponto ((risas)) charlar consolar etcetera etcetera 94yo fui hasta la familia yo cuando llegué al portón... no no voy no voy el padre me vió 95ENtra:: BUM... yo fui echada... sienta vas a a a almuerza con nosotros... la madre 96llorando la hermana así también uhm lo que pasó fue:: eh:: tuve que conté algunas 97 mentiritas es verdad sí... porque sabía que él la iba a 
buscar de coche (y no quiero dizer 98que no) yo sabía también que ya salían a mucho tiempo y (no era uma cosa) más 99reciente pero lo que intenté demostrar era que:: eh:: mi amiga no era lo que pensaban 100que era:: que no habían hecho que no había hecho ninguna tontería ....sí...y además 101que (el sabor de la conquista) que solamente se (tem tem tênia) una atracción... y:: 102después la la madre quedo más relajada y yo mire a ella y lê mire y dice que 103solamente el tiempo que iba a arreglar todo que no había ah que no adian resultaba 104hacer con que la:: con que mi amiga se cambiara de pensamiento de porque estaba 105muy abalada si... el tiempo pasó después mi amiga quedó muy agradecida conmigo... 106fue un caso que:: a la vez la sociedad tiende a hacer con las cosas sean muy gigantes 107 muy grandes cuando no es para tanto es para charlar para te comprender qué te 108 parece... no es? un buen diálogo... no puede dejar?

109B: si... eso que:: yo estaba hablando no hay no es que:: um diálogo no pueda inten por lo menos intentar

110A: amenizar

111B: amenizar sí yo también conozco una una chica que era casada y:: conoció a un:: a un muchacho en la Internet...

112A: uhmm la Internet

113B: y empezó a salir con él mucho... mucho tiempo y me contaba TOdo pero yo:: que 114voy a hablar no decía NAda así nada... pero:: ves que estás haciendo:: eres caSAda 115tal... y el marido descubrió... en una:: en una charla por teléfono entre los dos a la 116madrugada y:: ella vino a:: a preguntarme que:: que hacer (inspiración) de mí:: pero:: 117bueno...eh:; estabas haciendo una cosa equivocada sabes? ahora... están las 118consecuencias... descubrió... y:: intenta... charlar con él...ser sincera y ver si va a dar 119algún resultado

120A: y cuándo los padres se meten en las cosas? ay que uhm y:: é un tal de eh ay papá 121que yo ( ) estoy eh:: enojada con mi con mi mujer:: y no sé que voy a hacer:: y:: que 122hago y la madre queda en medio de la pelea sí... y eh todo está 
eh todo queda mucho 123 se cambia o sea... la verdad es que tienes una mejor proximidad con tu pareja los 124padres... eh:: hacen parte de esta conversación y la persona deja de ser sincera no hay 125 más el vínculo entre marido y mujer 


\section{Documento: Fita 4A (INTERMEDIÁRIO - Lado A)}

\section{Local: São Paulo}

Data: 30 de junho de 2005

Diálogo entre duas alunas do curso de Letras - espanhol

Documentador: Observador e promotor da conversação

Assunto: Infidelidade

Nível: Intermediário I

Faixa etária: 20 e 23 anos

1A: ah:: yo no:: no creo que sea:: correcto la:: la manera como está conduciendo 2este relacionamiento:: pero:: no creo también que sea:: eh:: bueno para ella 3continuar en un casamiento que no:: se/ que no:: es esté feliz... que no:: ahn:: 4que no la:: dé... la felicidad que busca porque el amor eh:: va hasta donde 5queremos... y si no estamos felices entonces:.... el amor se acaba el 6 casamiento es la es la base del casamiento es el amor...

7B:entonces... yo:.:: pienso que:: es posible que una persona este:: casada con 8otra y y de repente:: aparezca un:: amor::... después de:: diez años y::... no:: no 9tenemos que oh que hacer eh solamente la persona eh tendrá que saber que 10va a buscar si está haciendo la:: la cosa correcta o no:: porque:: es uma:: es 11 como un un dictado eh no haga cosas eh que no gustarías que... hicieran 12 contigo... entonces no haga con los otros... entonces... eso de estar saliendo... 13 con con el otro con una la otra persona para mí no es muy positivo es algo 14muy negativo... porque:: también la persona ten tiene un hijo... y esto es una 15cosa muy eh::... como puedo decir::... una cosa::... difícil que::... más o menos 16eh::... cambia las dos partes tanto de la mujer quanto de la crianza que... de la 17niña que:: que:: ella pueda pensar de su madre... y también... pienso que la 18 feliciDAd... siempre estamos a buscar y que::... cuando no:.:. no vemos que 19no:: que no está bien... entonces tivemos ten tendramos que buscar una otra 
20manera para que:.... seamos felices entonces... es mejor para mi... entonces

21que esta persona se divorcie y:: viva el amor que:: que:: encontrar o:: no sé::...

22pero:: esa cosa de estar con dos personas totalmente::... (llegadas) no es

23bueno... para::ni ni para ella ni tampoco para... las otras dos... personas que

24están... como si fuera::... un... triangulo amoROso no sé::

25A: ahn ahn... es que las moRAles sociAles:: las cosTUMbres:: llevan muchas 26 veces a a creer que es ese que el amor es algo eTERno que la vida es 27eTERna que el casamiento es eTERno entonces... eh cuando llega un punto $28 \mathrm{del}$ casamiento que no que no hay más amor no tiene más amor no tiene más 29respecto porque yo creo que:: el respecto es la base del casamiento y 30cuando:: el amor acaba simplemente no:: no tiene más una una relación:: hay 31 una amistad pero no:: tiene una amistad pero no tiene una::.... um amor:: algo 32más fuerte que lleve ese relacionamiento adelante... entonces:: cuando:: creo 33que:: llegue ese punto el es mejor que cada uno va a su LAdo o:: vas a ser 34feliz::... va a ser feliz::... vas a va a encontrar alguien que:: que:: vuelva con un 35sentimiento nuevo que::... que vas a hacer que VA a hacerte feliz y no:: que:: 36 simplemente cerrarse en um casamiento que no va a hacer que no va a 37llevarte a::: uhm... llevarte a::: ahn y:: que veo es que hoy en día eh muchas 38 veces por los hijos por una familia por lo que los los amigos van a pensar las 39 personas eh... cerran en esto de que NO:: es mi hijo y tal... eh:: creo que el 40psicólogo (debe resolver eso)... eh eh pien pensar en los hijos es fundamental 41 pero también no podemos... eh:: sacar eh:: sacar cul/ culpas:: en los hijos:: 42 simplemente porque su casamiento ah NO no fui feliz en mi vida porque usted 43era:: mi hijo... usted era alguien

44B:

46A:

\section{[}

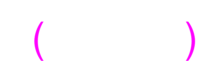

47hoy:: tú és un chico tu cres/ ha crecido... está:: grande... y puedes vivir su 48vida... ahora yo no... mi vida acabó:: cuando no amaba más su padre y el 49(cretino) me abandonó y fue con otra ((risas)) y eso vemos mucho por qué::... 50 porque en general:: los hombres no se:.... no se:... (tche) como voy a decir... 
51no:: no se:: no se:: PRENden a nada... simplemente... ah:: no no más... 52adiós... y las mujeres no es es las costumbres y las morales prenden prenden 53 muchas veces

54B: porque pienso:: en esta COsa:: que:: A. ... ha hablado... porque las mujeres 55son MUcho más sentimentales do que los hombres... los hombres son más:....

56racionales

\section{[}

57A: los

58hombres son de Marte las mujeres de Venus ((risas))

59B:

si:: son... más... racionales... entonces... no

60quiEro:: entonces... eh:: ya está::... me fue:: ((risas)) y:: y no quiero más...

61 pero:: las mujeres... piensan MUcho:: en::: los hijos principalmente para que...

62no van... a:: tener.: algunas... pierdas en... en su:: relacionaMIENto:: con su

63PAdre...o muchas veces por:: algunas cosas que:: VAN a decir eh algunos

64amigos ah:: donde está su padre ah:: mi madre no no no se queda más

65casada con mi padre y::: esto no es bueno para para el chico:: entonces...

66él... eh:: emPIEza a:: PENsar en::: MUchas cosas muchas veces eh:: conozco

67 muchas personas que... van al psicólogos... para:: mejorar la vida:: tanto en la 68escuela cuanto en su casa propiamente y::.: también... eh:: muchas veces...

69las mujeres no::... no dejan... de ser felices porque::: no::.... no hacen... eh:: lo 70que el corazón... manda... y simplemente... piensan... no:: no:: puedo eh::

71dejar de:: de:: dejar de mi maRldo:: porque... si no... que... que van a pensar

72mi familia... que van... a pensar la:: sociedad:: entonces:: 
73A:

(es porque piensan)

[

74B:

es una cosa muy compleja

75A:

es porque piensan... piensan que la... el el lo importante

76para los hijos son... el padre y la madre... y... no piensan que... mismo 77 separados ellos van a continuar sien/siendo padres y madres... simplemente 78 no son más CAsados... pero son... personas que... siempre van a tener dos 79dos Hljos::tres hijos cuatro hijos no sé cuántos te:: tengan pero::van a ser 80padres... Slempre... porque hijo no es algo momenTAneo... no es algo que:: 81eh::: que hoy es tu hijo eh mañana no es más... pero::: que no::: que... con 82esta... disculpa que NO:: el padre y la madre son fundamentales para:: el 83crecimiento y la el desarrollo de del niño... NO:.: el el la figura... paterna y la 84figura materna SON fundamentales... pero:.:no adelanta nada dos personas 85juntas que no son felices si te::: agriden se:: ma casi se matan todos los días... 86 eso creo que ca causa causa MUcho más problemas psicológicos que 87simplemente:: las personas se:: cada una:: eh... separadas... de su vidas en el 88caso::

89B: es porque::...hay a::: aquella COsa que:: el PAdre... es una figura muy 90imporTANte... en la faMllia... pero... hoy en dia... no es verDAd... no es verdad 91que un un padre está totalmente asegurado de del poder de mantener su 92familia o su trabajo porque muchas las veces la mujer que está::: eh::: 93empleAda... que está busCANdo cada dia más a a dar COsas a sus hijos 94mejorar eh su vida entonces... eh creo que:.:: la... figura paterna no está tan:: 95más:: así:: igual a antiguamente... que tendría que tener un::: un:: un padre 96que:: fuera:::

97A: que sostenta:: la

98familia

99B: 
100seria sí:: que sería como::una perSOna PRINcipal

101A:

el jefe de (la casa)

102B:

sí:: el jefe de la casa... hoy en día no es

103verdad... muchas mujeres eh:: eh::

104A:

105(son las jefas)

[

106B: sí:: son las jefas.. no sé:: como:: podemos decir y:: es verDAd porque:: 107eh:: los hombres son muchos... son muy:: eh:: momentaneos né::?... no 108piensan que van a hacer despues entonces... hoy es hoy mañana mañana 109y::: las mujeres no:: las mujeres son más... sencillas::

110A: $\quad$ (son las que más sufren con todo eso) ((risas))

111B:

son las que más sufren también por a::: al 112revés de:.... pensar... también eh:...... SIENten MUcho con:.... trabajan... 113PIENso que trabajan con los dos... con los sentimientos y con... la 114razón...pero:: los hombres solamente con la razón... pienso eso 


\section{Documento: Fita 5A (INTERMEDIÁRIO - Lado A)}

\section{Local: São Paulo}

Data: 24 de agosto de 2005

Diálogo entre duas alunas do curso de Letras - espanhol

Documentador: Observador e promotor da conversação

Assunto: Infidelidade

Nível: Intermediário I

\section{Faixa etária: 19 e 24 anos}

1A: eh:: quiero que hable un poco... sobre esto... porque:: pienso que:: es:: eh:: otro día 2hablamos mucho sobre... una situación... CAsi:: igual y:: pero:: hay una:: diferencia que 3es el casaMENto de:: de ellos... es una cosa más seria... pero también podemos pensar... 4cuando::: las personas no son casadas y::: tuvieron a algun tiempo un noviado... y::: una 5 de las personas se interesa por otra perSOna... pero le gusta MUcho el novio... MAS... 6tiene una atraci/atracción por otra persona... $y::$ se queda preocuPAda... queriendo eh:: no 7queriendo eh:: eh:: trair? traicionar su novio pero:: queRIENdo se quedar un poquito con 8el otro (risas) qué piensas B. por favor?

9B: yo creo que esto es un caso muy comPLEjo... principa principalmente... eh eh eh sendo 10 con un matrimonio... que es una cosa muy seria y te eh tem teniendo un hijo también

11A: pero um noviado también no es?

12B: también pero:: ahm::: cómo puedo decir... creo que una perSOna ahm eh tiene que 13decidir entre uno y el otro porque la situación se queda muy:: muy TONta... no:: sé:: la 14propia perSOna se enGAña y engaña los dos y y es una:: no sé no sé

15A: pero no da igual? en un casamiento y un noviado... también está el noviado serio y::: 16y:: la sociedad no ve con buenos ojos

17B:

es verdad 
18A:

una persona que::

19B:

es verdad

[

$20 \mathrm{~A}$

eh::que hace eso... el casamiento es MUY más

GRAve 21porque tiene un hijo... las personas tienen un hijo... también

22B: y es y están a diez años juntos...creo que esta mujer... tiene que dicidir... entre... uno 23de los dos

24A: qué piensa que llevó la mujer a a

25B creo que faltaba ALgo en en el matrimonio para para ella:: quedarse con otro se 26interesar por otro hombre:: ya le faltaba algo

27A: si fuera con:: usted... que:: que:: causaría eh este?

28B:cómo así?

29A: que causaría que:: tu:: eh:: se quedase:: interesada por otro:: que no su esposo? qué... 30faltaría en tu casamiento para que:: te quedase:.... interesada por otro hombre?

31B: no sé:: eh::: atención... cariño... creo que esas cosas eh::: a eh:: hace con que las otras 32personas procuren otras personas que (no)... si ella no tiene en su propia casa esto eh:: es 33involunTArio no es porque ella quiEre pero... cuando:: creo que cuando:: ella vio:: eh:: 34se dio:: cuenta de todo ESto ya estaba envolvida con otro hombre:.... no sé... y tú... qué 35piensas?

36A: de... de pronto:: cuando me deparé con:: con un asunto así:: eh:: ya hablaba... que:: a 37mí me parecía muy raro esta situación y:: no... a mí:: no::: no me quedaría confortable 38eh interesada por un hombre siendo que:: mantengo una relación con otro... a principio... 39después:: me quedé pensando al contrario... al revés... porque:: pienso também también 40en la perSOna que:: se interesó la mujer...en el 
caso... porque:: como:: tú habla habló:: 41 pienso que::: a ella... hace falta algo... entonces... veo por:: su su LAdo también... y me 42quedé:: (per) los dos

43B: no voy a a justificarla porque:: si ella:: tomó esta decisión:: e es porque:: faltaba $44 f a l t a b a$ algo y:: y no fue solo culpa de Ella... creo esto

45A: piensa que:: ella también... también piensa en:: su hijo su Hljo:: como:: como:: DEbe 46pensar en eso?

47B: no sé::... no sé:: un hijo:: en medio de esta situación es... es muy complejo... no sé... 48creo que para ella tomar...tomar una decisión:: con un Hljo... e e es muy más com... 49mucho más complejo

50A: y el hombre que:: no sé [

52A: $\quad$ y el hombre que está:: que está:: se envolviendo con ella... qué 53piensas?

54B: bueno... si si ella ya ya está con él a a un año si es un año... no quiere NAda serio con 55ella... porque si no:: ya ya habría ahm... dicho a ella para:: ahm... para se separar del 56marido y se quedar con él... oficialmente...yo yo pienso así

57A: y:: si ella no se separa:: no:: separa por:: causa del

58B: del hijo... no sé::

59A: puede ser que el hombre:: también no:: acepte muy bien

60B: el hijo

61A: el hijo de otro hombre 
63A: pero:: ella... entonces... no debía... se quedar muy apasionada por él... porque:: se... 64él... la quiere... también... tiene que querer:. el hijo

65B: es verdad

66A: bueno...

67B: complejo...

68Doc: que deberá hacer ese hombre si descubre que la mujer lo traiciona?

69A: pienso que él... se queda:: muy nervioso...muy nervioso

70B: pero:: él... tiene que hacer:: una:: un eXAmen de conCIENcia... porque:: (porque él) 71porque él... también tuvo... culpa... alguna culpa no?... no una GRANde culpa porque ella 72 hizo aquel aquel aquella aquello porque:: quiso:: sí?... pero:: ((tosse)) no no sé::

73A: pienso que de pronto el:: no va

74a:: quedarse

75B:

no::.:

76A:

[ penSANdo::

77B: no::

78A: en lo que ÉL hizo de:: grave

79B: de pronto... él va a quedar... muy nervioso... va a:: a querer matar lo o hombre 80A: va a se separar de

81 ella o (vivir) del hombre

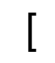


82B: va a querer eh:: (asignar) con el hijo... va:: a hacer locuras:: creo yo

83A: sacar todo que ella tiene con él que::consiguieron después del casamiento... el hombre 83va a se quedar el esposo va a quedarse muy... nervioso... pero:: el hijo va a sufrir mucho

84B: sí... creo que:: sí...el el el hijo es es la persona que más va a sufrir

85A: la persona traicionada NUNca:: nunca piensa primero en qué llevó su esposa a hacer 86eso... alguna cosa así

87B: es verdad...

88Doc.: si de repente el marido también la traiciona y por eso se fue a buscar una aventura 89extramatrimonial?

90A: si:: el mari el esposo hace lo mismo::

91B: no hay porque se quedar nervioso

92A: pero no se separan... vea... EL:: HAce la misma cosa que ella pero:: y si los dos sabes/ 93saben que:: un traiciona traiciona el otro pero:: no:: no encierra el matrimonio

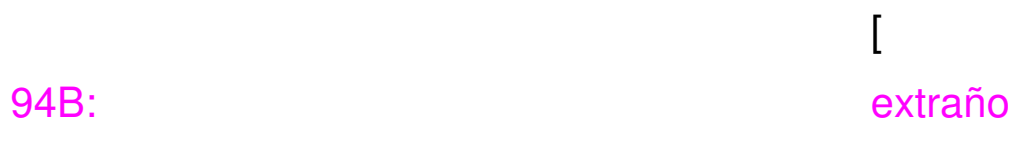

95A: porque:::

[

96B: $\quad$ por causa del Hljo

$$
\text { [ }
$$

97A: puede ser que se GUS:..ten:: ((risos)

98B:

un poQUI::.:to ah ::puede ser... 
99A:

o MUcho... o mucho... o:: por

100causa del:: hijo...

101B: pero::: es extraño:: los dos saberen

102A: $\quad$ yo pienso que el hijo no no no hacen hace TANta diferencia porque 103hay muchas mujeres que s/que:: que:: encierran un matrimomio y se quedan con un hijo 104y no tienen MIEdo

105B: ah sí:::

[

106A: solamente porque tienen un hijo... creo que:: el hijo no es tan:: no es el... como 107 decir... un problema muy grave

108B: $\quad$ hoy en día es normal:::

[

109A: $\quad$ puede ser que él:: él... sepa que la mujer es la mujer de su vida 110y ella en una visión apasioNA::da de mi persona ((risos)) que:: también... ella también:: 111 piensa que él... es hombr/el hombre de la vida:: de ella... algo así::

112B: puede ser... apenas una aventura... una atracción:: 
Documento: Fita 6A (INTERMEDIÁRIO - Lado A)

\section{Local: São Paulo}

Data: 29 de agosto de 2005

Diálogo entre duas alunas do curso de Letras - espanhol

Documentador: Observador e promotor da conversação

Assunto: Infidelidade

Nível: Intermediário II

Faixa etária: 24 e 33 anos

1A: la IN-fi-de-li-DAD....sí...é....cuánto TIEMpo estás está casada la chica? 2Doc.: diez años

3A: diez años... ahm:: yo pienso que::: cuando la vida no está buena... tenemos 4que cambiar... y pienso también que las personas son libres:: y:: pero... 5que...eh:: el compañero:: necesita de un:: respecto... entonces::: qué piensa B.? 6B: yo conozco a alguien que:: pasa por esta situación:: es un hombre... que::: 7está casado ha diez años también y el:: por algún motivo que:: yo no sé:: no 8conozco:: eh:: trayó:: no sé:: su:: su esposa:: con un una JOven de quince 9años... entonces:: puede ser porque::: él piense que:: ya pasó de la edad y 10 quiere:.... quiere::... ver si:.....si:.....si:.......a (hay)

11A: quiere una aventura...

12B: sí::

13A: por ejemplo...

14B: o no:: 15A: en la vida 16B:

o no::.: porque:: el se 17apasionó:: por:: la chica de quince años... y dejó su mujer:: con un hijo recién 18nacido:.... y:: y:: después... de:: de:: seis meses VOLvió para quedarse con su 
19mujer:: por causa de su hijo... NO por GUStar de su mujer:: porque::: a a gustar 20 no no no no le gustaba más a mucho tiempo... eh::

21A: sentía falta del hijo::

22B: sí... MUcha falta...

23A: no sé:: PIENso que::: esta:: esta amiga que::: Doc. eh:::: nos contó::... tiene 24que pensar muy bien... porque:: romper un relacionamiento es algo muy:: 25serio... y:: la chica puEde... arrependerse después::

26B: aunque son TRES vidas

27A: sí

28B: sí:: es la vida del chico:: la vida de ella:: la vida del del de su marido:: de su 29esposo:: o no?... cuatro vidas:.: la vida del otro...

30A: sí... y:.: están juntos:.... eh:: casi diez años... sí?... entonces:: pienso que es 31 una decisión muy difícil:: pero::... pienso que ella... tiene que tomar la decisión:: 32porque:: no puede vivir infeliz::

33B: sí::... pero creo que:.:. ella debe:...... conversar con su esposo a respecto de:: 34lo que está:: lo que está pasando:....lo que está:: lo que está:: haBENdo... de 35error:: para que:.:... su su:: casamiento no no no:: ocurra bien

36A: sí... y también:: se::: está:: intereSAda en una otra perSO::na... tiene que::... 37pri priMEro::... eh::: deciDIR:: la situación conyugal...

38B:

sí

39A:

para después:: salir con una otra

40persona

41B: sí:: también... no debe NUN::ca envolver su HIjo ((risos))

42Doc.: vosotras traicionaríais?

43A: yo:.... ya:... lo hice.. Una vez... en el pasado... porque:.:: mi relacionamiento 44estaba muy MAL... entonces:.... ((risos)) yo::: co-metí la traición...sí?:: pero $45 a H O r a . .$. yo pienso que no... que:: yo estoy más madura y no pienso que:: soy 46capaz de trair novamente

47B: pienso lo mismo... creo que:: para... ocurrir una traición:: ahm uno:: uno una 48de las personas debe de estar:.... eh:: de no debe de estar satisfecha con con 
49lo relacionamiento.. sí? entonces si esto ocurre:: TIEne que:: haber algo... hay 50 algo pasando...

51Doc.: y si estuvierais en un país... en una ciudad... donde todo fuera permitido 52incluso traicionar fuera permitido... traicionariais?

53A: no::: yo pienso que:: un relacionamiento tiene que:: traer felicidad... y se:: 54estás estás feliz con la relación:: no:: neceSlta traicionar::

55B: pienso lo mismo ((rizos))

56Doc.: y el hijo:: qué pasa en la cabeza de un hijo que:: por si acaso sabe que la 57 madre traiciona al padre?

58B: creo que:: es una... situación así::... difícil:: porque:: es un es un chico::sí? 59tiene nueve años no... no no:: para ÉL... eh:: la unión de su padre y de su 60MAdre es una cosa muy importante para su crecimiento... ELLOS son los 61espejos de él... y:: y:: no creo que:: el va pensar:: oba:: qué BUEno:: voy ahora 62tener dos casas... dos cuartos...sí? e el eh:: eh:: a::: a:: a mí me parece que::: 63 el ve esto como una cosa MAla se siente... muy TRISte con:: tudo que ocurre 64A: creo que los hijos siempre sufren... con:: la separa separación o cuando la 65relación de los padres se van mal... se va mal... pero pienso que:: es una 66realiDAD... que los hijos tienen que... eh:: encarar::

67Doc.: entonces sería mejor se hubiera una separación y el hijo...

68A: sí... creo que la separación... si no están felices... la paREja no se ama 69más:: la separación es:: la mejor alternativa...

70B: pero nunca se olvidando que:: cuando uno se separa del otro... 71siempre...eh:: jugan:: lo lo eh:: sus Hljos... u uno contra:: uno... de ellos sí? y:: 72 esto no se puede ocurrir

73A: los hijos se quedan eh:: MUY sepaRAdos::

74B: sí

75A: divididos:.: no:: nun:: nunca saben:.... para:::

76B:

77A:

[

cuál de los dos:: 
79A:

s/se debe dar más

80atención...

81Doc.: la preferencia suele ser gustar de quién... de la madre?... no es 82 normalmente la madre que queda con el hijo?

83B: no ((risos))

84Doc.: te parece que hay un cambio?

85B: sí::: porque... tiene que ver... quién... quién tiene más estructura para:: $86 q u e d a r s e$ con:: con el hijo... sí? si es el padre o la madre... porque:.:: yo 87 conozco un hombre... que:: que quedose con su Hija... porque la madre no 88tenía condiciones de de criarla sí? y otro... que que que la hija está con su 89 madre porque él no tiene con quién dejar su hijo

90A: depende también de la edad de los hijos... porque:.... estos pueden... 91 optar... elegir... cuál de los dos quiere... vivir... junto... pero:.: creo que:: 92legalmente:: las madres tienen la preferencia... solamente no ocurre cuando:: la 93madre no:: tiene la

94B: tiene condición

[

95A: condición

96B: sí::

[

97A: $\quad$ psicológica... principalmente... de quedarse con el hijo 98B: sí::

99Doc.:: hay una actriz que consumía drogas...

100B: no es:.:

101Doc.: cómo se llamaba? que me olvidé:::era::

102B: Vera Fischer

103A: .: uhm uhm... se pasó esto no?

104B: sí:.:

[

105Doc.: (ha casado) 
106B: $\quad$ el denunció:: sí?

[

107A: $\quad$ ahm ahm

[

108B: sí:: pero:: el hijo aHOra está con ella... sí?

109Doc.: y ahora ya se ha recuperado

110B: sí:: después de MUcho tiempo:: ella consiguió:: quedarse con su hijo en su 111casa 